\title{
4. SPORES AND POLLEN FROM CRETACEOUS DEPOSITS OF THE EASTERN NORTH ATLANTIC OCEAN, DEEP SEA DRILLING PROJECT, LEG 41, SITES 367 AND 370
}

Ida Z. Kotova, Geological Institute of the USSR Academy of Sciences, Moscow, USSR

\section{SUMMARY}

Four spore-pollen assemblages from Sites 367 and 370 are distinguished: Neocomian, Aptian(?) to lower Albian, upper Albian to lower Cenomanian, and Cenomanian. These are correlated to synchronous spore-pollen assemblages of West Africa, Eurasia, and North America.

\section{INTRODUCTION}

The samples in the study come from Site 370 (water depth $4216 \mathrm{~m}$ ) drilled in the Morocco Basin and Site $367,150 \mathrm{~km}$ west of (Guinea Bissau) Africa in the Cape Verde Basin (water depth $4748 \mathrm{~m}$ ) (Figure I). Six samples from Site 370 contained spores and pollen, but only two samples from Site 367 had spores and pollen. The remaining nine samples looked at proved either barren or contained only sporadic specimens of spores and pollen.

The samples were treated with hydrochloric acid. potassium, sodium hydroxide, and cadmium liquid. The specimens were prepared on glycerine jelly sealed with BF-2 glue or paraffin. All specimens are now stored at the Geological Institute of the USSR Academy of Sciences, No. 3949.

The results of the palynological analysis of the samples from both sites are summarized in Table 1 in percent content of spores and pollen. Table 2 is a range chart of some genera and species at Site 370.

The photomicrographs in Plates 1 thru 14 were done by means of microscope "Lumipan" with the microphotographic device MFN-12.

\section{SITE 370: MOROCCO BASIN}

Well-preserved spores and pollen were distinguished from six samples in the depth interval of 749 to 996 meters. Microplankton (dinoflagellates, acretarcheans) are very abundant and diverse. Four spore-spollen assemblages are distinguished within the above interval.

Assemblage $\mathrm{I}$ is represented by spores and pollen from the lowermost samples $(41, \mathrm{CC}, 996.0 \mathrm{~m})$. The assemblage is characterized by abundant Classopollis (70)' and pollen Dicheiropollis etruscus (72), spores Concavissimisporites variverrucatus (5), Concavissimisporites sp. (6), Tuberositriletes montuosus (7), Ceratosporites parvus (9), Cicatricosisporites brevilaesuratus (16), Cicatricosisporites $\mathrm{sp} . \mathrm{sp} .(18,19)$, Gleicheniidites senonicus (26), Coronatispora valdensis (27), and Patellasporites distaverrucosus (30). Pollen

'The number in parentheses is the item number of a taxon in the "Systematics" section of this paper.

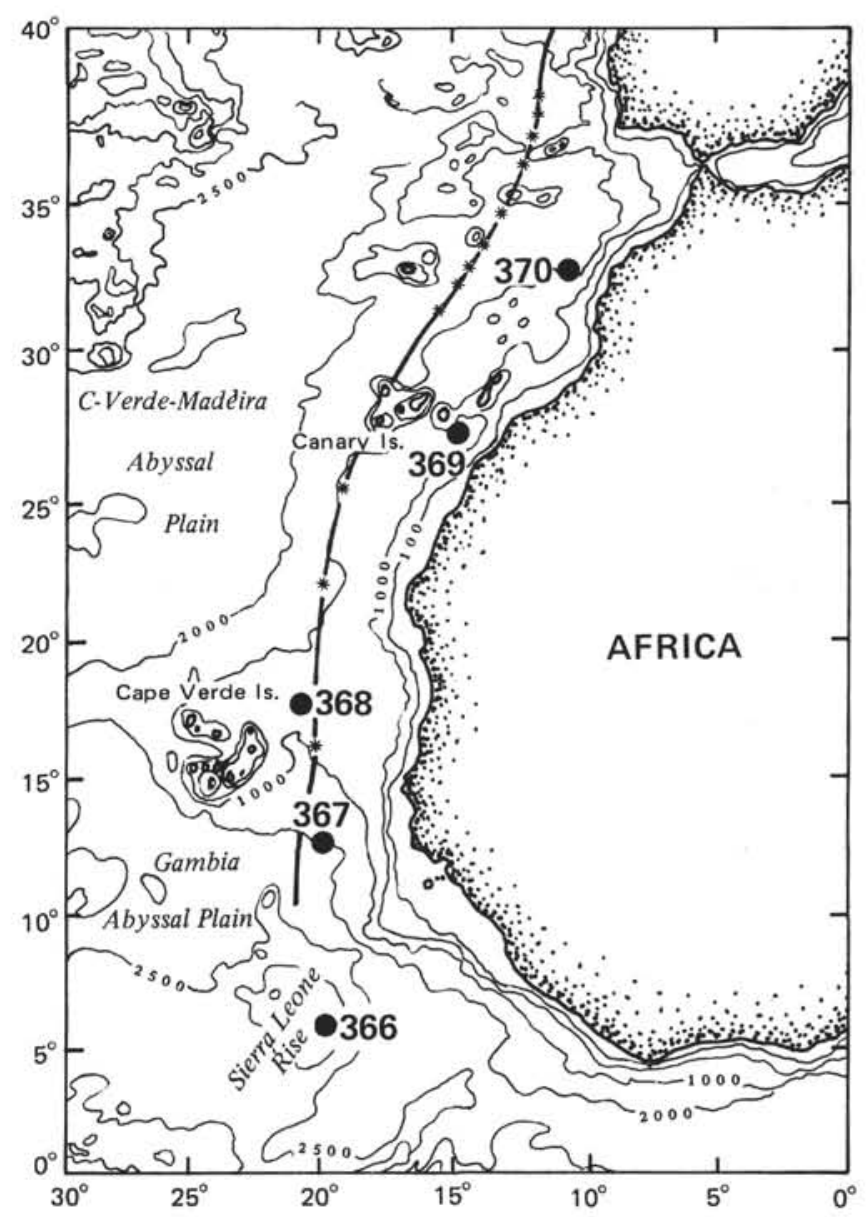

Figure 1. Location of DSDP Sites 367 and 370.

Ephedripites sp. sp. $(45,47,48)$ and Steevesipollenites $(56,64)$ occur, but are not numerous. Pollen of the bisaccate conifers Pinuspollenites sp. (38), Podocarpidites sp (39), Parvisaccites radiatus (40), and Vitreisporites pallidus (41) occurs but the angiosperm pollen are absent.

Most of the above genera and species are known from Cretaceous deposits of many regions of the world, with a wide vertical distribution. Tuberositriletes montuosus was described from the Weldian of East Germany (Döring, 1964). Cicatricosisporites brevilaesuratus is representative of the Barremian and Aptian of England (Kemp, 1970), and in North America it is found in Albian sediments (Brenner, 1963). Ceratosporites parvus is found throughout the Barremian, Aptian, and Albian deposits of England (Kemp, 1970) and North America (Brenner, 1963). Dicheiropollis etruscus was first described from the 
TABLE 1

Percentage Distribution Chart of Spores and Pollen in Cretaceous Sediments of Holes 370 and 367

\begin{tabular}{|c|c|c|c|c|c|c|c|c|c|}
\hline & & \multicolumn{6}{|c|}{ Hole 370} & \multicolumn{2}{|c|}{ Hole 367} \\
\hline & & $41, \mathrm{CC}$ & $32, \mathrm{CC}$ & $31, \mathrm{CC}$ & $30, \mathrm{CC}$ & $29, \mathrm{CC}$ & $27, \mathrm{CC}$ & $23, \mathrm{CC}$ & $21, \mathrm{CC}$ \\
\hline \multicolumn{2}{|c|}{ Depth $(m)$} & 996.0 & 844.0 & 834.5 & 815.5 & 796.5 & 758.5 & 787.0 & 701.5 \\
\hline \multicolumn{2}{|c|}{ Total of Grains } & 296 & 302 & 425 & 451 & 556 & 782 & 365 & 201 \\
\hline \multicolumn{2}{|c|}{ Spores } & 10.8 & 7.4 & 6.5 & 5.7 & 8.1 & 11.2 & 14.0 & 11.8 \\
\hline \multicolumn{2}{|c|}{ Gimnospermae } & 89.2 & 90.3 & 89.1 & 89.0 & 85.9 & 75.2 & 71.0 & 80.2 \\
\hline \multicolumn{2}{|c|}{ Angiospermae } & - & 2.3 & 4.4 & 5.3 & 6.0 & 13.6 & 15.0 & 8.0 \\
\hline 1 & Cyathidites minor & - & 0.6 & 0.2 & 0.2 & 0.2 & 0.3 & 0.2 & 0.9 \\
\hline 2 & C. australis & 0.7 & 0.3 & 0.2 & - & 0.7 & 0.1 & 0.8 & - \\
\hline 3 & Stereisporites antiquasporites & - & 0.6 & 0.5 & - & - & - & - & - \\
\hline 4 & Leptolepidites verrucatus & - & 0.6 & - & - & - & 0.1 & - & - \\
\hline 5 & Concavissimisporites variverrucatus & 0.3 & 0.3 & - & - & - & - & - & 0.5 \\
\hline 6 & Concavissimisporites $\mathrm{sp}$. & 0.7 & - & - & - & - & - & - & - \\
\hline 7 & Tuberositriletes montuosus & 0.7 & - & - & - & - & - & - & - \\
\hline 8 & Verrucosisporites sp. & 0.7 & - & 0.2 & 0.2 & - & - & 0.5 & - \\
\hline 9 & Ceratosporites parvus & 1.0 & - & - & - & - & - & - & - \\
\hline 10 & Klukisporites sp. & 0.3 & 0.3 & - & 0.4 & - & 0.1 & - & - \\
\hline 11 & Reticulatisporites sp. 1 & - & - & - & - & - & - & 1.6 & - \\
\hline 12 & Reticulatisporites sp. 2 & - & - & - & - & - & - & 0.5 & - \\
\hline 13 & Cicatricosisporites proxiradiatus & - & 0.6 & 0.7 & 0.2 & 0.5 & 0.2 & - & - \\
\hline 14 & C. venustus & - & 0.3 & 0.2 & - & - & - & - & - \\
\hline 15 & C. microstriatus & 0.3 & - & - & - & - & - & - & - \\
\hline 16 & C. brevilaesuratus & 1.6 & 0.3 & - & 0.2 & - & - & 0.2 & - \\
\hline 17 & C. potomacensis & - & - & - & - & - & - & 0.5 & 0.5 \\
\hline 18 & Cicatricosisporites sp. 1 & 0.7 & - & - & - & - & - & - & - \\
\hline 19 & Cicatricosisporites sp. 2 & 1.0 & - & - & - & - & - & - & - \\
\hline 20 & Cicatricosisporites sp. 3 & - & - & 0.5 & - & - & - & - & - \\
\hline 21 & Cicatricosisporites sp. 4 & - & - & 0.9 & - & - & 0.6 & - & - \\
\hline 22 & Cicatricosisporites sp. 5 & - & 1.0 & - & - & - & - & - & - \\
\hline 23 & Appendicisporites sp. 1 & - & 1.0 & - & - & - & - & - & - \\
\hline 24 & Appendicisporites sp. 2 & - & 0.3 & - & 0.2 & - & - & - & - \\
\hline 25 & Appendicisporites $\mathrm{sp} .3$ & - & - & - & - & - & - & 0.8 & - \\
\hline 26 & Gleicheniidites senonicus & 0.7 & 0.6 & 1.6 & 1.7 & 6.0 & 0.8 & - & - \\
\hline 27 & Coronatispora valdensis & 0.7 & 0.3 & - & - & - & - & - & - \\
\hline 28 & Matonisporites sp. & 0.7 & 0.3 & 0.2 & 1.0 & 0.3 & - & 0.2 & - \\
\hline 29 & Perotriletes pannuceus & - & - & 0.9 & 0.9 & 0.2 & 0.1 & 2.0 & 2.5 \\
\hline 30 & Patellasporites distaverrucosus & 0.7 & - & 0.2 & 0.2 & - & - & 4.5 & 0.9 \\
\hline 31 & Coptospora sp. & - & - & - & - & - & 0.2 & 0.2 & 0.5 \\
\hline 32 & Reticulatasporites jardinus & - & - & 0.2 & 0.5 & 0.2 & 8.5 & 0.8 & 0.5 \\
\hline 33 & Elaterosporites klaszi & - & - & - & - & - & 0.2 & 1.0 & 3.5 \\
\hline 34 & Elaterocolpites sp. & - & - & - & - & - & - & - & 2.0 \\
\hline 35 & Galeacornea causea & - & - & - & - & - & - & 0.2 & - \\
\hline 36 & Cerebropollenites mesozoicus & 0.3 & 1.0 & - & - & 0.2 & 0.1 & - & - \\
\hline 37 & Tsugaepollenites trilobatus & 1.3 & 0.3 & - & - & 0.2 & - & - & - \\
\hline 38 & Pinuspollenites sp. & 4.0 & 0.6 & 0.2 & - & 0.2 & 0.3 & - & 0.5 \\
\hline 39 & Podocarpidites sp. & 0.3 & 1.5 & - & - & 0.2 & 0.1 & - & - \\
\hline 40 & Parvisaccites radiatus & 0.3 & 1.3 & - & - & 0.2 & - & - & - \\
\hline 41 & Vitreisporites pallidus & 1.3 & 0.3 & 0.5 & 0.4 & 1.4 & 0.2 & - & - \\
\hline 42 & Inaperturopollenites sp. & - & - & - & 0.2 & 5.3 & - & - & - \\
\hline 43 & Araucariacites australis & 0.3 & - & 0.2 & 0.4 & 6.2 & 0.2 & 1.4 & 0.9 \\
\hline 44 & Eucommiidites sp. & 0.7 & 0.3 & 0.2 & 0.4 & - & 0.7 & - & - \\
\hline 45 & Ephedripites multicostatus & 0.7 & 2.0 & 0.4 & 0.6 & 0.5 & 3.3 & 4.8 & - \\
\hline 46 & Ephedripites pentacostatus & - & - & - & - & - & - & 0.5 & 0.5 \\
\hline 47 & Ephedripites sp. 1 & 0.7 & 1.0 & 1.7 & - & - & - & 1.0 & - \\
\hline 48 & Ephedripites sp. 2 & 2.0 & 0.2 & 0.4 & 0.2 & - & - & - & - \\
\hline 49 & Ephedripites sp. 3 & - & - & - & - & 0.5 & 3.5 & 0.2 & 0.5 \\
\hline 50 & Ephedripites jansonii & - & - & - & - & 0.5 & 0.6 & 1.0 & 0.5 \\
\hline 51 & Ephedripites sp. 4 & - & - & - & - & - & 0.7 & - & - \\
\hline 52 & Ephedripites sp. 5 & - & 0.6 & 1.7 & 0.4 & 0.3 & 0.3 & - & 0.5 \\
\hline 53 & Ephedripites sp. 6 & - & - & - & - & - & 0.1 & - & - \\
\hline 54 & Ephedripites sp. 7 & - & - & - & - & - & - & 0.2 & 0.5 \\
\hline 55 & Steevesipillenites binodosus & - & - & - & - & - & 0.3 & 1.6 & 0.5 \\
\hline 56 & Steevesipollenites $\mathrm{sp} .1$ & 0.3 & 0.6 & - & - & - & - & - & - \\
\hline 57 & Steevesipollenites dajani & - & - & - & - & 0.2 & - & 0.2 & - \\
\hline 58 & Steevesipollenites sp. 3 & - & - & - & - & - & - & 0.5 & - \\
\hline 59 & Steevesipollenites sp. 4 & - & - & - & - & - & - & 0.2 & - \\
\hline 60 & Steevesipollenites sp. 5 & - & - & - & - & - & 0.2 & - & - \\
\hline
\end{tabular}


TABLE 1 - Continued

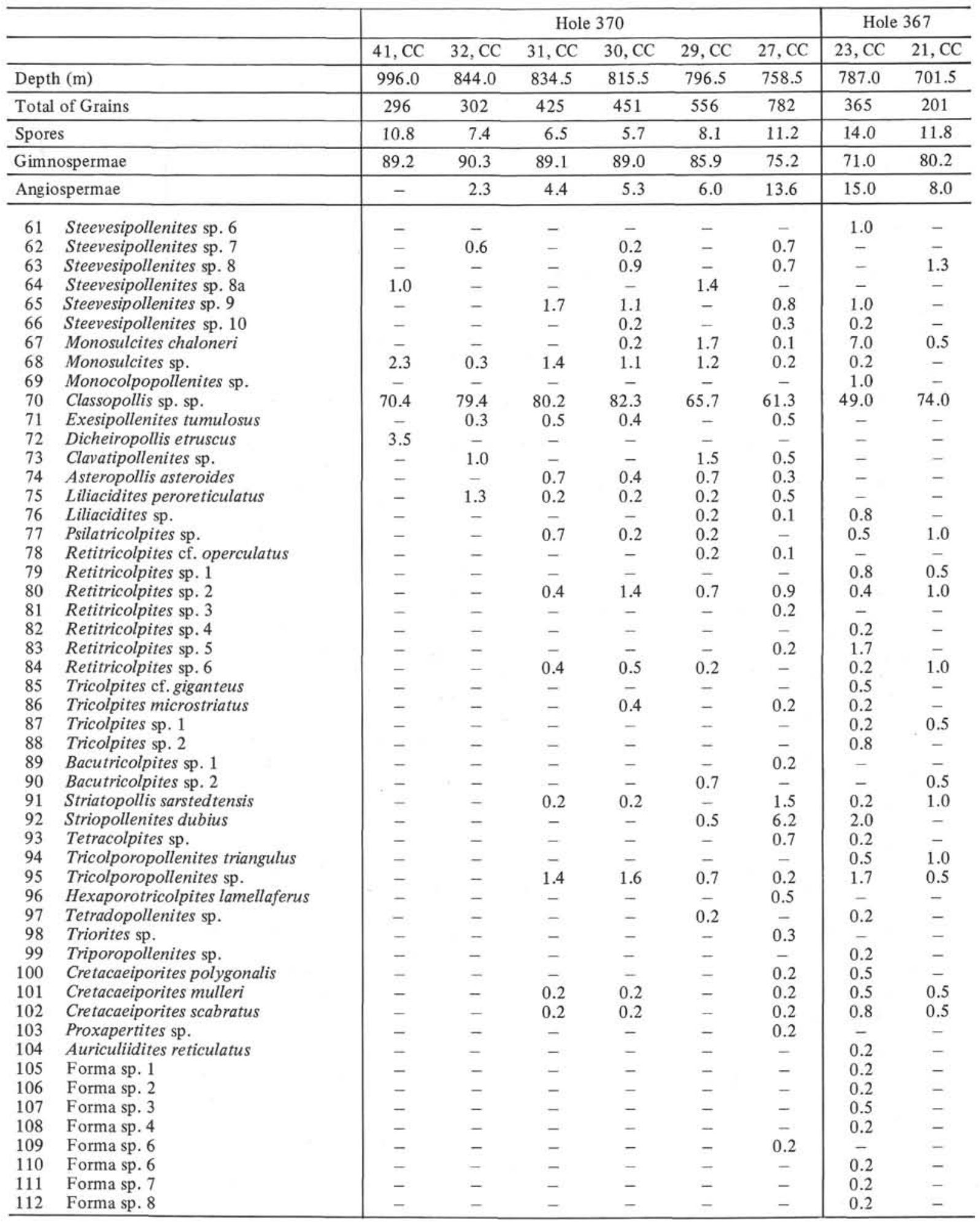

marine Neocomian in Italy (Trevisan, 1971). Later it was recognized in Neocomian deposits of Africa and the Atlantic coast of South America, but it was not found beyond the Neocomian (Jardiné et al., 1973). Thus, the age of Assemblage I is Neocomian.

Assemblage II is found in Core $32(844.0 \mathrm{~m})$. Dicheiropollis etruscus, restricted to the Neocomian, disappears and some new genera and species appear; Cicatricosisporites proxiradiatus (13), Cicatricosisporites venustus (14), Cicatricosisporites sp. 5 (22) Appendicisporites sp. 1 (23) and Appendicisporites sp. 2 (24). Just as in the previous assemblage, there are many Classopollis sp. (68), as well as the pollen of bisaccate conifers and pollen Ephedripites sp. sp. $(45,47,48,52)$ 
TABLE 2

Pollen Diagram of Species in Cretaceous Sediments of Hole 370

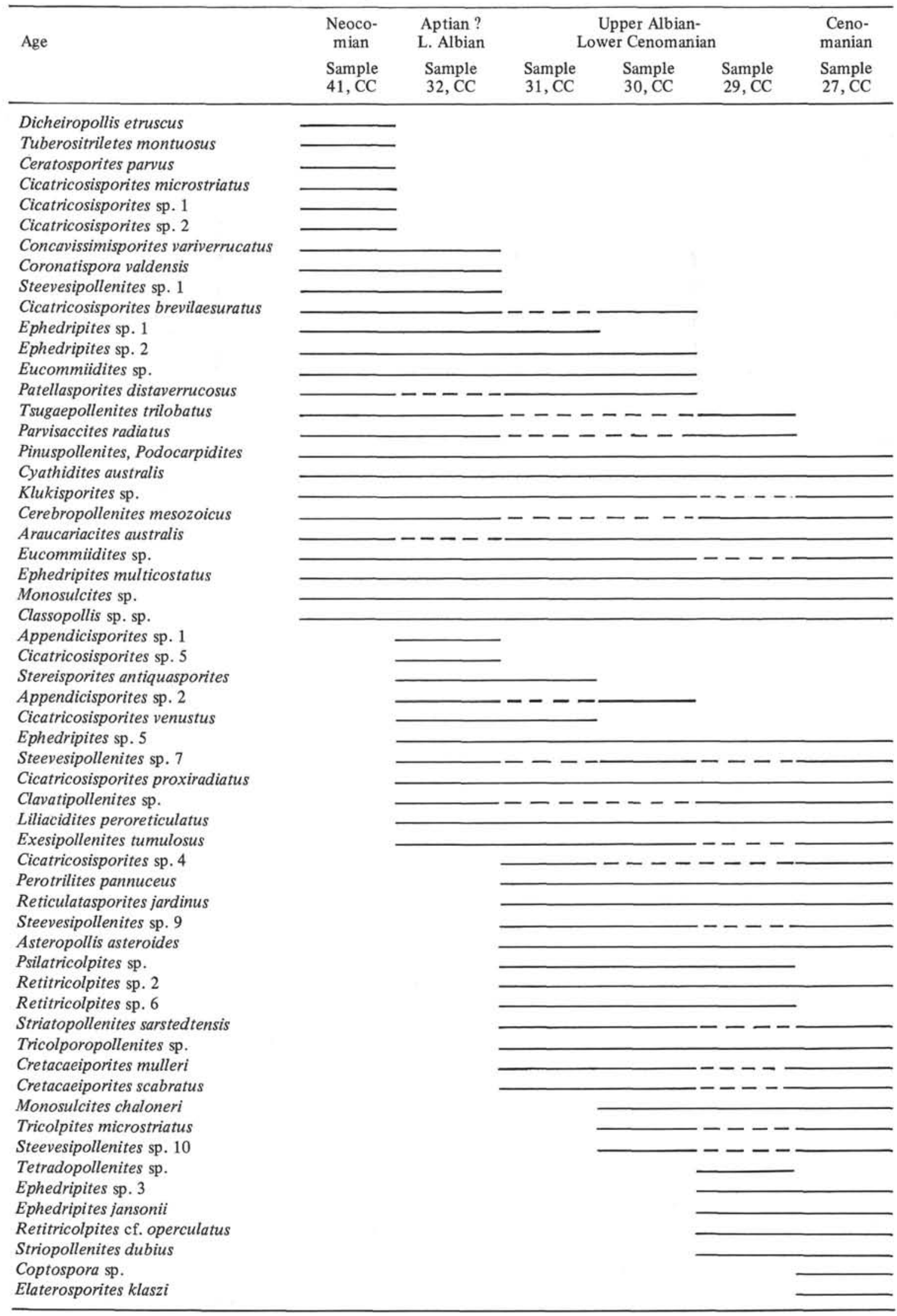


TABLE 2 (Continued)

\begin{tabular}{|c|c|c|c|c|c|c|}
\hline \multirow[b]{2}{*}{ Age } & \multirow{2}{*}{$\begin{array}{l}\text { Neoco- } \\
\text { mian } \\
\text { Sample } \\
41, \text { CC }\end{array}$} & \multirow{2}{*}{$\begin{array}{l}\text { Aptian? } \\
\text { L. Albian } \\
\text { Sample } \\
32 \text {, CC }\end{array}$} & \multicolumn{3}{|c|}{$\begin{array}{c}\text { Upper Albian- } \\
\text { Lower Cenomanian }\end{array}$} & \multirow{2}{*}{$\begin{array}{l}\text { Ceno- } \\
\text { manian } \\
\text { Sample } \\
27, \text { CC }\end{array}$} \\
\hline & & & $\begin{array}{l}\text { Sample } \\
31, \mathrm{CC}\end{array}$ & $\begin{array}{l}\text { Sample } \\
30, \text { CC }\end{array}$ & $\begin{array}{l}\text { Sample } \\
29, \text { CC }\end{array}$ & \\
\hline \multicolumn{7}{|l|}{ Ephedripites sp. 4} \\
\hline \multicolumn{7}{|l|}{ Ephedripites sp. 6} \\
\hline \multicolumn{7}{|l|}{ Steevesipollenites binodosus } \\
\hline \multicolumn{7}{|l|}{ Retitricolpites sp. 5} \\
\hline \\
\hline \multicolumn{7}{|l|}{ Hexaporotricolpites lamellaferus } \\
\hline \\
\hline \multicolumn{7}{|l|}{ Cretacaeiporites polygonalis } \\
\hline Proxapertites sp. & & & & & & \\
\hline
\end{tabular}

and Steevesipollenites sp. 1 (56). This assemblage is characterized by the appearance of a monocolpate pollen of angiosperms Clavatipollenites (73) and Liliacidites peroreticulatus (75) and no angiosperm pollen of the tricolpate type.

Most of these spores have a wide vertical distribution. Spores Appendicisporites sp. 1 and Cicatricosisporites sp. 5 were only observed in Assemblage II. Jardiné and Magloire (1965) point out the presence of similar spores of the genus Appendicisporites in the Aptian to lower Albian of Senegal, and Boltenhagen (1965) describes Appendicisporites for the Aptian of Gabon and Congo. The appearance of pollen Clavatipollenites and Liliacidites peroreticulatus is assigned to the Barremian to Aptian (Kemp, 1970); Doyle, 1969). The disappearance of the Dicheiropollis etruscus pollen argues against a Barremian age of this assemblage. The absence of the angiosperm pollen of the tricolpate type does not allow a middle Albian age. Thus, the age of the assemblage is given as Aptian to early Albian. This assemblage is similar to Assemblage XI of the Aptian to early Albian distinguished from lower Cretaceous deposits of Senegal (Jardiné and Magloire, 1965).

Assemblage III was singled out from Samples 31, $\mathrm{CC}, 30, \mathrm{CC}$, and $29, \mathrm{CC}$ (interval 796.0 to $834.5 \mathrm{~m}$ ). This assemblage has spores Perotrilites pannuceus (29), Reticulatasporites jardinus (32), Cicatricosisporites sp. 4 (21), and a greater abundance of Gleicheniidites senonicus spores (26) than occurs in the lower assemblages. The pollen Classopollis (70) is abundant as before, Ephedripites sp. sp. $(45,47,48,52)$, and Steevesipollenites sp. 9 (65) are not common and grains of bisaccate conifers are rare. The assemblage is characterized by the presence of the angiosperm pollen of the tricolpate, tricolporate and periporate types. This pollen is represented by Asteropollis asteroides (74), Psilatricolpites sp. (77), Retitricolpites sp. sp. (80, 84), Tricolporopollenites sp. (91), Cretacaeiporites mulleri (101), and Cretacaeiporites scabratus (102). The pollen Striatopollis sarstedtensis (91) and Tricolpites microstriatus (86) occur in Sample 30, CC, and Striopollenites dubius (92) and Retitricolpites cf. operculatus (78) occur in Sample 29, CC. Perotrilites pannuceus is known from Albian to Cenomanian deposits of Peru (Brenner, 1963), the Albian to Cenomanian of the Senegal and lvory Coast (Jardiné and Magloire, 1965), and Albian and Albian to Cenomanian deposits of Brazil (Herngreen, 1973). Reticulatasporites jardinus was recognized in the Aptian to Cenomanian of the Senegal, Albian to Cenomanian of Nigeria, Aptian, Albian and Cenomanian of Gabon and Congo (Jardiné et al., 1974b); in the Albian and Albian to Cenomanian of Brazil (Herngreen, 1973) and Peru (Brenner, 1963). Asteropollis asteroides was defined from the middle Albian of Oklahoma, USA (Hedlung and Norris, 1968). This species was found in upper Albian and Cenomanian of England (Laing, 1975), in the Cenomanian of France (Azema et al., 1972), and in Cenomanian and Turonian in Australia (Dettmann, 1973). Pollen of the genus Retitricolpites appears almost simultaneously throughout the world from the lower middle Albian, and its abundance and diversity increase in the upper Albian and Cenomanian. In West Africa and South America, the first grains of the tricolpate type also first appear at this level (Jardiné and Magloire, 1965; Muller, 1966; Herngreen, 1973). The first tricolporate (Tricolporopollenites) grains of angiosperms are observed not earlier than the late Albian, and sometimes only from the Cenomanian (Doyle, 1969; Muller, 1970; Dettmann, 1973). The tricolporate grains first appear in West Africa and Brazil in the Albian to Cenomanian (Jardiné and Magloire, 1965; Herngreen, 1973). The periporate pollen of the genus Cretacaeiporites is known from Albian deposits of West Africa, Peru, and Brazil. Cretacaeiporites scabratus was defined as Multiporopollenites sp. from the Turonian to lower Cenomanian of Ivory Coast (Jardiné and Magloire, 1965). Boltenhagen (1965) singled out a similar species from the Albian to Cenomanian of Gabon and in Brazil this species was restricted to Albian to Cenomanian deposits (Herngreen, 1973). Cretacaeiporites mulleri was described from the upper Albian to Cenomanian of Brazil, from the Turonian of Peru (Brenner, 1968), and Turonian to lower Cenomanian of Senegal and Ivory Coast (Jardiné and Magloire, 1965). Striatopollis sarstedtensis was defined from the lower Paleogene of East Germany (Krutzsch, 1959). However, this species was also found in the upper Albian to lower Cenomanian of England (Laing, 1975) and in the Cenomanian of Portugal (Groot and Groot, 1962). Striopollenites dubius is representative of the Albian and Cenomanian of Senegal and Ivory Coast (Jardiné 
and Magloire, 1965). Tricolpites microstriatus was described from the Turonian of Senegal and Ivory Coast.

Thus, most of the forms mentioned above have a range within the upper Albian to lower Cenomanian. Comparison with assemblages from the near-shore basins of West Africa (Jardiné and Magloire, 1965) and South America (Herngreen, 1973) confirms the upper Albian to lower Cenomanian correlation.

Assemblage IV is found in Sample 27, CC (758.5 m). The composition of spores does not vary significantly, but the percent of Reticulatasporites jardinus increases up to $8.5 \%$, and one grain of Elaterosporites klaszi (33) and one grain of $E$. verrucatus were found. The abundances of Ephedripites and Steevesipollenites pollen increase up to $15 \%$. Steevesipollenites binodosus (55), Ephedripites sp. 4 (51), and Ephedripites sp. 6(53), which were not found in the underlying samples, appear in this assemblage. The Classopollis pollen content decreases somewhat. Sporadic specimens of the bisaccate coniferous pollen are present. The pollen of angiosperms is represented by Retitricolpites $\mathrm{sp}$. sp. (80, 81, 83), Bacutricolpites sp. (89), Striopollenites dubius (92), Tricolpites microstriatus (86), Striatopollis sarstedtensis (91), Cretacaeiporites mulleri(101), and C. scabratus (102). A number of new species and genera appears, such as Proxapertites sp. (103), Cretacaeiporites polygonalis (100), Hexaporotricolpites lamellaferus (96), Tetracolpites $\mathrm{sp}$. (93), and Triorites sp. (98).

The genera unique to this assemblage are Tetracolpites sp., Hexaporotricolpites lamellaferus, and Triorites sp. Tetracolpites sp. was defined by Jardiné and Magloire (1965) in the upper Albian to lower Cenomanian deposits of the Senegal and Ivory Coast. A similar form was found in the Albian to Cenomanian of Portugal (Groot and Groot, 1962). Hexaporotricolpites appears in the upper Albian to lower Cenomanian in Brazil (Herngreen, 1973). This pollen has a range from the upper Albian to Cenomanian in West Africa (Jardiné et al., 1972). The pollen Triorites sp. (98) has not been found in other localities in Africa or South America. The upper Cenomanian of West Africa is characterized by a triporate form, Triorites africanicus, described by Jardiné from the upper Cenomanian of Senegal. This same species is also found in the upper Cenomanian of Brazil. However, this species was not observed in these DSDP samples. Nevertheless, the presence of the triporate pollen (Triorites sp.) allows the assignment of a late Cretaceous age to this assemblage and perhaps it can be refined to the lower to middle Cenomanian.

\section{SITE 367: CAPE VERDE BASIN}

Seven samples of black shales were analyzed from the interval of 625.0 to 844.0 meters. Only two contain pollen and spores; sample 23, CC $(787.0 \mathrm{~m})$ and Samples 21, CC (701.5 m).

Sample 23, CC contains a great number of wellpreserved spores and pollen, and a small amount of microplankton. The spore assemblage is mostly Patellasporites distaverrucosus (30), Reticulatisporites sp. $(11,12)$, Verrucosisporites sp. (8), Reticulatasporites jardinus (32), Perotrilites pannuceus (29), Coptospora sp. (31), Elaterosporites klaszi (33), Galeacornea causea
(35), Cicatricosisporites sp. sp. $(17,16)$, and Appendicisporites sp. 3 (25). Pollen of Ephedripites and Steevesipollenites is rather abundant with $S$. binodosus (55) and large forms of Steevesipollenites sp. 3 (58). The Classopollis pollen make up $49 \%$ of the assemblage. Pollen of angiosperm plants are very diverse and are represented by tricolpate, tricolporate and periporate forms. One triporate grain was found (Triporopollenites sp. [99]) as was some questionable forms belonging, perhaps, to angiosperm plants $(105,106$, $107,108,110,111,112)$. Sample $21, \mathrm{CC}$ has a high abundance of the Classopollis pollen and elaterebearing forms (Elaterosporites klaszi, and Elaterocolpites sp.). One grain of Pinuspollenites $\mathrm{sp}$. was found. Angiosperm pollen from Sample 21, CC are not common and are less diverse than in Sample 23, CC.

The assemblages from the two samples are similar to the Cenomanian Assemblage IV from Site 370, although minor differences appear. No pollen of angiosperm - Trorites sp. (94) and Hexaporotricolpites lamellaferus - were found in Hole 367 and spores of Gleicheniidites senonicus, pollen of bisaccate conifers Vitreisporites pallidus, Podocarpidites sp., and only one grain of Pinuspollenites sp. were found. On the other hand, there are species at Site 367 samples that were not observed in Hole 370: Steevesipollenites sp. 3 (58), Auriculiidites reticulatus (104), Tricolpites cf. giganteus (85), and Triporopollenites sp. (99) known from younger deposits of Africa (Turonian to Cenomanian). However, the presence of Perotrilites pannuceus, Reticulatasporites jardinus, Patellasporites distaverrucosus, and Striopollenites dubius allows an age assignment of not younger than Cenomanian for this assemblage.

\section{COMPARISON WITH WEST AFRICA AND SOUTH AMERICA}

The assemblages from Sites 370 and 367 are quite similar to assemblages from the near-shore basins of West Africa and South America. Many genera and species unique to the assemblages of West Africa and South America are found in the DSDP samples. For example, the Classopollis pollen is a predominant element common to Cretaceous deposits of Brazil and Africa. The pollen of the genera Ephedripites and Steevesipollenites occurs in the above deposits in lesser amounts than occurs in Brazil, Senegal, and Ivory Coast. The spore of Perotrilites pannuceus and Reticulatasporites jardinus are widespread in Albian and Albian to Cenomanian deposits of Brazil, Senegal, and Ivory Coast. They are also common in Albian to lower Cenomanian sediments from Site 370, but their abundance does not exceed $1 \%$ of the assemblage, with the exception of the Cenomanian where $R$. jardinus increases up to $8.5 \%$.

Elatere-bearing forms are presented in the Albian to Cenomanian of Brazil, Senegal, Ivory Coast, Nigeria, Gabon, and Algeria by a great genetic diversity (Elaterosporites, Elaterocolpites, Elateroplicites, Senegalosporites, and Sofrepites). Only rare specimens of the Elaterosporites and Elaterocolpites were recognized in the DSDP samples.

The angiosperm pollen in the spore-pollen assemblages from Sites 370 and 367 is represented by many species common to the assemblages from West 
Africa and Brazil. Striopollenites dubius is representative of the Albian to Cenomanian of Senegal and Ivory Coast, but it was not recorded in Brazil. Hexaporotricolpites lamellaferus was found in the upper Albian of Gabon, Congo, Angola, and in the upper Albian to lower Cenomanian of Brazil, but it was not found in the Albian to Cenomanian of Senegal and Ivory Coast. Cretacaeiporites polygonalis occurs in Senegal in the upper Albian to lower Cenomanian; in Brazil it appears from the lower Albian, and in high abundance in the Albian to Cenomanian. Rare specimens of this species were recognized in Cenomanian assemblages from Sites 370 and 367 . Single specimens Cretacaeiporites mulleri and $C$. scabratus were observed in upper Albian to Cenomanian assemblages from Sites 370 and 367, but these species are common in upper Albian to lower Cenomanian sediments of Brazil. These species were recognized in Senegal only in the upper Cenomanian and Turonian.

The assemblages from Site 370 are characterized by the presence of pollen of bisaccate conifers represented by Pinuspollenites sp., Podocarpidites sp., Parvisaccites radiatus, Vitreisporites pallidus, none of which are recorded in Cretaceous assemblages of Brazil, Peru, Senegal, Gabon, Congo, and Kameron (Herngreen, 1973; Brenner, 1968; Boltenhagen, 1965; Jardiné and Magloire, 1965). In addition, assemblages from Site 370 contained Gleicheniidites senonicus, Stereisporites antiquasporites, Tuberositriletes montuosus, Corontispora valdensis and pollen of angiosperm Asteropollis asteroides, none of which are known from Cretaceous spore-pollen assemblages of Brazil and West Africa, but are found in Cretaceous spore-pollen assemblages from Eurasia, North America, and Australia.

\section{COMPARISON WITH OTHER REGIONS}

Comparison of the assemblages from the lower and middle Cretaceous sediments of Sites 370 and 367 with those from near-shore basins of West Africa and South America and assemblages from other areas of the world strongly support the existence of a special AfricanSouth American province, a suggestion first made by Herngreen (1974).

The lower to middle Cretaceous assemblages of the African-South American province are characterized by the following:

1) Presence of the following genera and species peculiar to this province: Dicheiropollis etruscus, ${ }^{2}$ Reticulatasporites jardinus, Elaterosporites, Elaterocolpites, Galeacornea, Senegalosporites, Elateroplicites, Sofrepites, Elateropollenites, Striopollenites dubius, Hexaporotricolpites lamellaferus, $H$. emelianovi and Cretacaeiporites.

2) Absence of the following genera widespread in lower and middle Cretaceous deposits of Eurasia, North America, Australia: Pilosisporites, Trilobosporites, Stereisporites, Foraminisporis,

\footnotetext{
${ }^{2}$ Decheiropolis etruscus was first defined from the Neocomian of Italy, but since then, it has only been found in Africa and South America.
}

Kuylisporites, Aequitriradites, Cooksonites, Couperisporites, Taurocusporites, Densoisporites, and Rouseisporites.

3) The pollen Ephedripites and Steevesipollenites has a greater diversity of species in the African-South American province than in Eurasia, North America, and Australia.

The common stages of development of flora in the African-South American province do not differ from other regions. The tricolpate pollen of angiosperms always appears in the middle or at the end of the lower Albian and is represented mostly by reticulate forms. The tricolporate pollen of angiosperm appears from the upper Albian to lower Cenomanian and the triporate forms occurs from the Cenomanian, and at the same levels as occur in Eurasia, North America, and Australia. This must have been a time when the vegetation of this province was unique and the genera and species were restricted to the province only.

\section{CONCLUSIONS}

The data suggest that the supply of spores and pollen feeds the area of Site 370 from the shores of West Africa, Eurasia, and, very likely, North America. This assumption is based on the presence of typical African genera and species, as well as pollen of bisaccate conifers and some spores (Gleicheniidites senonicus, Stereisporites antiquasporites, Tuberositriletes montuosus, Coronatispora valdensis), pollen Asteropollis asteroides which is not known from Cretaceous sediments of Africa, but is found in Eurasia and North America.

The assemblage studies are well correlated to synchronous ones of West Africa and Brazil. However, a much lesser content of most genera and species, as compared to the assemblages from the near-shore basins of West Africa and Brazil is worth noting. They include spore Perotrilites pannuceus, Reticulatasporites jardinus, pollen of gymnosperms Ephedripites and Steevesipollenites, as well as the pollen of angiosperm plants. The sediments penetrated at Site 367 originated relatively close to the shore line of West Africa, as evidenced by the presence of large forms of angiosperms that could hardly be transfered over larger distances.

The climate that prevailed during accumulation of Cretaceous sediments from Sites 370 and 367 must have been warm and dry, as evidenced by abundant pollen Classopollis and the diversity of pollen Ephedripites and Steevesipollenites.

\section{SYSTEMATICS}

Below is the list of taxa found. Geological and Geographical distribution of the previously defined species is given. The distribution of taxa in the sections studied is presented in Table 1.

Anteturma Sporites H. Potonie, 1893

Infraturma Laevigati Bennie and Kidston emend. R. Potonie, 1956

Genus CYATHIDITES Couper, 1953

1. Cyathidites minor Couper, 1953

(Plate 1, Figure I)

Worldwide distribution in Mesozoic sediments. 
2. Cyathidites australis Couper, 1953

(Plate 1, Figures 2, 3)

Worldwide distribution in Mesozoic sediments.

Genus STEREISPORITES Pflug, 1953

3. Stereisporites antiquasporites (Wilson and Webster) Dettmann, 1963.

(Plate 1, Figure 5)

Worldwide distribution in Mesozoic sediments.

Infraturma Apiculati Bennie and Kidston emend. Potonie. 1956

Genus LEPTOLEPIDITES Couper, 1953

4. Leptolepidites verrucatus Couper, 1953

(Plate 1, Figures 6-8)

Worldwide distribution in Mesozoic sediments.

Genus CONCAVISSIMISPORITES Delcourt and Sprumont emend.

Delcourt, Dettmann, Hughes, 1963

5. Concavissimisporites variverrucatus (Couper) Brenner, 1963

(Plate 1, Figure 9)

Lower Cretaceous of USA (Brenner, 1963) and England (Couper, 1958; Kemp, 1970).

6. Concavissimisporites sp.
(Plate 1, Figures 10,11)

Genus TUBEROSITRILETES Döring, 1964

7. Tuberositriletes montuosus Döring, 1964

(Plate 1, Figure 12)

Wealden of GDR.

Genus VERRUCOSISPORITES (Ibr.) Smith and Mitarbeiter, 1964

8. Verrucosisporites sp.

(Plate 1, Figures, 13, 14)

Genus CERATOSPORITES Cookson and Dettmann, 1958

9. Ceratosporites parvus Brenner, 1963

(Plate 1, Figures 15)

Barremian-Aptian and Albian of England (Kemp, 1970) and Albian of the USA (Brenner, 1963).

Infraturma Murornati R. Potonie and Kremp, 1954

Genus KLUKISPORITES Couper, 1958

10. Klukisporites sp.

(Plate 4, Figures 2, 3)

Genus RETICULATISPORITES (Ibr.) Neves, 1964

11. Reticulatisporites sp. 1.

(Plate 4, Figure 12)

12. Reticulatisporites $\mathrm{sp} . \mathrm{Z}$

(Plate 4, Figures 13-15)

Genus CICATRICOSISPORITES Pontonie and Gelletich, 1933

13. Cicatricosisporites proxiradiatus Kemp, 1970 (Plate 1, Figure 16)

Aptian and Albian of England (Kempt, 1970).

14. Cicatricosisporites venustus Deak, 1963 (Plate 1, Figure 17)

Upper Aptian of Hungary, Lower Cretaceous of England (Kemp, 1970) and Upper Cretaceous of Spain (Van Ameron, 1965).

15. Cicatricosisporites microstriatus Jardiné and Magloire, 1965 (Plate 1, Figure 18)

Aptian-Albian of Ivory Coast (Jardiné and Magloire, 1965).
16. Cicatricosisporites brevilaesuratus Couper, 1958 emend. Kemp, 1970

(Plate 2, Figure 1-3)

Barremian and Aptian of England (Couper, 1958; Kemp, 1970) and in Potomac Group of USA (Brenner, 1963).

\section{Cicatricosisporites potomacensis Brenner, 1963} (Plate 2, Figure 7)

Barremian-Aptian of Potomac Group of the USA (Brenner, 1963) and Barremian of England (Kemp, 1970).

18. Cicatricosisporites sp. 1 (Plate 2, Figures 4, 5)

19. Cicatricosisporites sp. 2 (Plate 2, Figure 6)

20. Cicatricosisporites sp. 3 (Plate 2, Figure 8)

21. Cicatricosisporites sp. 4 (Plate 3, Figures 1, 2)

22. Cicatricosisporites sp. 5 (Plate 3, Figures 3, 4)

Genus APPENDICISPORITES Weyland et Krieger, 1953

23. Appendicisporites sp. 1 (Plate 3, Figures 5, 6)

24. Appendicisporites sp. 2 (Plate 3, Figure 7)

25. Appendicisporites sp. 3 (Plate 3, Figure 8)

Infraturma Tricrassati Dettmann, 1963

Genus GLEICHENIIDITES (Ross ex Delcourt and Sprumont) Dettmann, 1963

26. Gleicheniidites senonicus Ross, 1949 (Plate 3, Figures 9-13)

Worldwide distribution in upper Mesozoic sediments.

Genus CORONATISPORA Dettmann, 1963

27. Coronatispora valdensis (Couper) Dettmann, 1963 (Plate 4, Figure 1)

Wealden-Albian of England (Kemp, 1970) and Albian of Canada (Playford, 1971).

Infraturma Auriculati Schopf emend. Dettmann, 1963

Genus MATONISPORITES Couper, 1958

28. Matonisporites sp.

(Plate 1, Figure 4)

Suprasubturma Perinotrilites Erdtman, 1947

Genus PEROTRILITES (Erdman) ex Couper, 1953

29. Perotrilites pannuceus Brenner, 1963

(Plate 4, Figure 5, 6)

Albian of Maryland, USA (Brenner, 1963), Albian-Cenomanian of Péru (Brenner, 1968); Albian-Cenomanian of Senegal and Ivory Coast basin (Jardiné et Magloire, 1965); Albian-Cenomanian of Brazil (Herngreen, 1973).

Infraturma Patinati Butterworth and Williams, 1958

Genus PATELLASPORITES Groot and Groot emend. Kemp, 1970. (Plate 4, Figures 8-11)

Neocomian-Upper Aptian of England (Kemp, 1970) and Potomac Group, USA (Brenner, 1963). 
Turma Hilates Dettmann, 1963

Genus COPTOSPORA Dettmann, 1963

31. Coptospora sp.
(Plate 4, Figure 7)

Incertae sedis

Genus RETICULATASPORITES Leschik, 1955

32. Reticulatasporites jardinus Brenner, 1968 (Plate 3, Figures 15, 16)

Aptian-Cenomanian of Senegal, Ivory Coast, Nigeria, Cameroun, Gabon, Congo (Jardiné et al., 1974b), Albian-Cenomanian of Peru (Brenner, 1968).

\section{Infraturma Appendiciferi ?}

Genus ELATEROSPORITES Jardiné, 1967

33. Elaterosporites klaszi (Jardiné and Magloire) Jardiné, 1967 (Plate 5, Figure 1-5)

Upper Albian-Lower Cenomanian of Peru (Brenner, 1968).

Genus ELATEROCOLPITES Jardiné et Magloire emend. Jardiné 1967

\section{Elaterocolpites sp.}

(Plate 5, Figures 8, 9)

Genus GALEACORNEA Stover, 1963

35. Galeacornea cf. causea Stover, 1963 (Plate 5, Figure 6)

U. Albian to L. Cenomanian of Senegal and Gabon (Jardiné, 1967; Stover, 1963).

Anteturma Pollenites Potonie, 1931

Infraturma Saccizonati Bhardwaj, 1957

Genus CEREBROPOLLENITES (Couper) Nilsson, 1958

36. Cerebropollenites mesozoicus (Couper) Nilsson, 1958 (Plate 10, Figures 19, 20)

Worldwide distribution in Upper Mesozoic sediments.

Genus TSUGAEPOLLENITES Potonie et Venitz emend. Potonié, 1958

37. Tsugaepollenites trilobatus (Balme) Dettmann, 1963 (Plate 10, Figure 16, 17)

Worldwide distribution in upper Mesozoic sediments.

Subturma DISACCITES Cookson, 1947

Genus PINUSPOLLENITES Raatz, 1937

38. Pinuspollenites sp.

(Plate 10, Figure 6, 15)

Genus PODOCARPIDITES Cookson ex Couper, 1953

39. Podocarpidites sp.

(Plate 10, Figure 7-11)

Genus PARVISACCITES Couper, 1958

40. Parvisaccites radiatus Couper, 1958 (Plate 10, Figures 12-14)

Worldwide distribution in lower Cretaceous sediments.

\section{Genus VITREISPORITES LESCHIK, 1955}

41. Vitreisporites pallidus (Reissinger) Nilsson, 1958

(Plate 9, Figures 27, 28)

Worldwide distribution in Mesozoic sediments.

Subturma Azonaletes Luber emend. Potonié and Kremp, 1954

Genus INAPERTUROPOLLENITES (ex Thoms. et Pfl. 1955) emend. R. Potonié, 1966

42. Inaperturopollenites sp. (Plate 9, Figure 2)

Genus ARAUCARIACITES Cookson ex Couper, 1953

43. Araucariacites australis Cookson, 1947 (Plate 9, Figure 3)

Worldwide distribution in Mesozoic and Tertiary sediments.

Subturma Praecolpates Potonie and Kremp, 1954

Genus EUCOMMIIDITES Erdtman emend. Couper, 1958

44. Eucommiidites sp.

(Plate 9, Figures 23-26)

Subturma Polyplicates Erdtman, 1952

Genus EPHEDRIPITES Bolchovitina, 1953

45. Ephedripites multicostatus Brenner, 1963 (Plate 6, Figure 1-5)

Albian of USA (Hedlund and Norris, 1968; Brenner, 1963).

46. Ephedripites pentacostatus Brenner, 1968 (Plate 7, Figure 8, 9)

Albian-Cenomanian of Peru (Brenner, 1968), Albian of Ivory Coast (Jardiné and Magloire, 1965).

47. Ephedripites sp. I

(Plate 6, Figures 8-14)

48. Ephedripites sp. 2

(Plate 6, Figures 15-18)

49. Ephedripites sp. 3

(Plate 6, Figures 19-26)

50. Ephedripites jansonii (Pocock) Muller, 1968.

(Plate 7, Figures 1-5)

51. Ephedripites sp. 4

(Plate 7, Figures 6, 7)

52. Ephedripites sp. 5

(Plate 7, Figures 6, 7)

53. Ephedripites sp. 6

(Plate 9, Figure 1)

54. Ephedripites sp. 7

(Plate 7, Figure 22)

Genus STEEVESIPOLLENITES Stover, 1964

55. Steevesipollenites binodosus Stover, 1964 (Plate 7, Figure 10-14)

Albian-Turonian of Senegal (Stover, 1964), upper Albian-lower Cenomanian of Brazil (Herngreen, 1973).

56. Steevesipollenites sp. I

(Plate 7, Figure 15-17)

57. Steevesipollenites dajani Brenner, 1968 (Plate 7, Figure 18)

Albian-Cenomanian of Peru (Brenner, 1968). 
58. Steevesipollenites sp. 3 (Plate 7, Figure 19)

59. Steevesipollenites sp. 4 (Plate 7, Figure 20)

60. Steevesipollenites sp. 5 (Plate 7, Figure 21)

61. Steevesipollenites sp. 6 (Plate 8, Figures 1-4)

62. Steevesipollenites $\mathrm{sp.} 7$ (Plate 8, Figures 5, 6)

63. Steevesipollenites sp. 8 (Plate 8, Figure 7-9)

64. Steevesipollenites sp. 8a (Plate 8, Figures 10-12)

65. Steevesipollenites sp. 9 (Plate 8, Figures 13, 14)

66. Steevesipollenites sp. 10 (Plate 8, Figures 15-18)

Subturma Monocolpates Iversen et Troels-Smith, 1950

Genus MONOSULCITES Cookson ex Couper, 1958

\section{Monosulcites chaloneri Brenner, 1963}

(Plate 9, Figures 15, 16)

Albian of the USA (Brenner, 1963; Hedlund and Norris, 1968); Aptian-Albian of England (Kemp, 1970).

68. Monosulcites sp.

(Plate 9, Figures 17-22)

Genus MONOCOLPOPOLLENITES Thomson and Pflug, 1953

69. Monocolpopollenites sp.

(Plate 9, Figures 29, 30)

Subturma Monoporines Naumova, 1939

Genus CLASSOPOLLIS Pflug emend. Couper, 1958

70. Classopollis sp. sp.

(Plate 9, Figures 4-14)

Genus EXESIPOLLENITES Balme, 1957

71. Exesipollenites tumulosus Balme, 1957 (Plate 10, Figure 18)

Worldwide distribution in upper Mesozoic sediments.

Genus DICHEIROPOLLIS Trevisan, 1971

72. Dicheiropollis etruscus Trevisan, 1971 (Plate 10, Figures 1-5)

Neocomian of Italy (Trevisan, 1971), Neocomian of Angola, Congo, Gabon, and Brazil (Jardiné et al., 1974a)

Angiospermous pollen grains

Genus CLAVATIPOLLENITES Couper, 1958

73. Clavatipollenites sp.

(Plate 11, Figures 1, 2)

Genus ASTEROPOLLIS Hedlund and Norris, 1968

74. Asteropollis asteroides Hedlund et Norris, 1968 (Plate 11, Figures 2, 3)

Middle Albian of USA (Hedlund and Norris, 1968); upper Albianmiddle Cenomanian of England (Laing, 1975); CenomanianTuronian of Eastern Australia (Dettmann, 1973).
Genus LILIACIDITES Couper, 1953

75. Liliacidites peroreticulatus (Brenner) Singh, 1971 (Plate 11, Figures 5-8)

Upper Albian-middle Cenomanian of England (Laing, 1975); upper Barremian-Albian Maryland, USA (Brenner, 1963); upper Albian-Cenomanian of Alberta, Canada (Norris, 1967); Albian of Peru (Brenner, 1968); middle Cenomanian of France (Azema et al., 1972); middle Albian of Oklahoma, USA (Hedlund and Norris, 1968).

76. Liliacidites sp.

(Plate 11, Figures 9, 10)

Genus PSILATRICOLPITES van der Hammen ex van der Hammen and Wymstra, 1964

77. Psilatricolpites sp. (Plate 11, Figure 20)

Genus RETITRICOLPITES van der Hammen ex van der Hammen and Wymstra, 1964

78. Retitricolpites cf. operculatus Herngreen, 1973 (Plate 12, Figure 8)

Upper Albian-Cenomanian of Brazil (Herngreen, 1973).

\section{Retitricolpites sp. I \\ (Plate 11, Figure 14)}

80. Retitricolpites sp. 2

(Plate 11, Figures 15-17)

81. Retitricolpites sp. 3

(Plate 11, Figure 18)

82. Retitricolpites sp. 4 (Plate 13, Figure 1)

83. Retitricolpites sp. 5

(Plate 13, Figures 2, 3)

84. Retitricolpites sp. 6

(Plate 11, Figure 19)

Genus TRICOLPITES Cookson ex Couper, 1953

85. Tricolpites ef. giganteus Jardiné and Magloire, 1965 (Plate 13, Figures 20, 21)

Turonian-Senonian of Senegal and Ivory Coast (Jardiné and Magloire, 1965).

86. Tricolpites microstriatus Jardiné and Magloire, 1965 (Plate 12, Figures 14-17)

The species was described from the Turonian of Senegal and Ivory Coast.

87. Tricolpites sp. 1

(Plate 11, Figures 11-13)

88. Tricolpites sp. 2

(Plate 13, Figures 4, 5)

Genus BACUTRICOLPITES (van der Hammen) Pierce 1961

$$
\begin{aligned}
& \text { 89. Bacutricolpites sp. } 1 \\
& \text { (Plate 12, Figures 1-3) }
\end{aligned}
$$

90. Bacutricolpites sp. 2

(Plate 12, Figure 4)

Genus STRIATOPOLLIS Krutzsch, 1959

91. Striatopollis sarstedtensis Krutzsch, 1959

(Plate 12, Figures 18, 19)

Paleocene of DGR (Krutzsch, 1959); upper Albian-lower Cenomanian of Portugal and the upper Albian-lower Cenomanian of England (Laing, 1975). 
Genus STRIOPOLLENITES Rouse, 1962

92. Striopollenites dubius Jardiné and Magloire, 1965 (Plate 12, Figures 12, 13)

Upper Albian-lower Cenomanian of Senegal and Ivory Coast (Jardiné and Magloire, 1965).

\section{Genus TETRACOLPITES Vemal, 1952}

93. Tetracolpites sp.

(Plate 13, Figures 6-8)

Genus TRICOLPOROPOLLENITES Pflug et Tomson, 1958

94. Tricolporopollenites triangulus Groot et al., 1961 (Plate 11, Figures 23, 24)

Cenomanian of USA (Groot et al., 1961).

95. Tricolporopollenites sp.

(Plate 11, Figures 25-31)

Genus HEXAPOROTRICOLPITES Boltenhagen, 1967

96. Hexaporotricolpites lamellaferus Jardiné et al., 1972 (Plate 12, Figures 9-11)

Upper Albian of Gabon, Congo and Angola (Jardine et al., 1972), upper Albian-lower Cenomanian of Brazil (Herngreen, 1973).

Genus TETRADOPOLLENITES Sittler, 1954

97. Tetradopollenites sp.

(Plate 11, Figures 21, 22)

Genus TRIORITES Cookson ex Couper, 1953 emend. Potonie, 1960

98. Triorites sp.

(Plate 13, Figures 15-18)

Genus TRIPOROPOLLENITES Pflug and Tomson, 1953

99. Triporopollenites sp.

(Plate 12, Figure 20)

Genus CRETACAEIPORITES Herngreen, 1973

100. Cretaceous polygonalis (Jardiné and Magloire) Her ngreen, 1973

(Plate 13, Figures 9, 10)

Upper Albian-lower Cenomanian of Senegal, Aptian-upper Cenomanian of Ivory Coast (Jardiné and Magloire, 1965); Albian of Peru (Brenner, 1968); lower middle Albian-lower Cenomanian of Brazil (Herngreen, 1973).

101. Cretacaeiporites mulleri Herngreen, 1973 (Plate 13, Figures 11, 12)

Upper Albian-lower Cenomanian of Brazil (Herngreen, 1973); Turonian-lower Cenomanian of Senegal and Ivory Coast (Jardiné and Magloire, 1965).

\section{Cretacaeiporites scabratus Herngreen, 1973}

(Plate 13, Figures 13, 14)

Upper Albian-lower Cenomanian of Brazil (Herngreen, 1973); Turonian-lower Senonian of Senegal and Ivory Coast (Jardiné and Magloire, 1965); Albian-Cenomanian of Gabon (Boltenhagen, 1965).

Genus PROXAPERTITES van der Hammen, 1956

103. Proxapertites sp.

(Plate 12, Figures 5, 6)

\section{Genus AURICULIIDITES Elsik, 1965}

104. Auriculiidites reticulatus Elsik, 1965

(Plate 13, Figure 19)

Campanian of Peru (Elsik, 1965); Turonian of Peru (Brenner, 1968); lower Maestrichtian of Senegal (Jardiné and Magloire, 1965).

\section{Incertae sedis}

105. Forma sp. 1

(Plate 14, Figure 1)

106. Forma sp. 2

(Plate 14, Figure 2)

107. Forma sp. 3

(Plate 14, Figures 3, 4)

108. Forma sp. 4

(Plate 14, Figure 5)

109. Forma sp. 5

(Plate 14, Figure 6)

110. Forma sp. 6

(Plate 14, Figure 7)

111. Forma sp. 7

(Plate 14, Figure 8)

112. Forma sp. 8

(Plate 14, Figure 9)

\section{REFERENCES}

Azema, C., Durand and Médus, 1972. Des miospores du Cénomanian Moyen: Paleobiol. Continentale, v. 3, no. 4.

Boltenhagen, E., 1965. Introduction á la palynologie stratigraphique du bassin sedimentaire de l'Afrique équatoriale: Mem. Bur. Rech., Geol. Minieres, p. 32.

1967. Spores et Pollen du Cretace supérieur du Gabon: Pollen et Spores, v. 9, no. 2.

Brenner, G., 1963. The spores and pollen of the Potomac group of Maryland: Dept. Geol. Mines Water Resources Bull., p. 27.

1968. Middle Cretaceous spores and pollen from Northeastern Peru: Pollen et Spores, v. 10, no. 2.

Couper, R. A., 1958. British Mesozoic microspores and pollen grains. A systematic and stratigraphic study: Paleontographica, Abt. B, v. 103, p. 4-6.

Dettmann, M. E., 1963. Upper Mesozoic microfloras from Southeastern Australia: Roy. Soc. Vict. Proc., p. 77.

1973. Angiospermous pollen from Albian to Turonian sediments* of Eastern Australia: Geol. Soc. Australia Spec. Publ. 4.

Döring, H., 1964. Trilete Sporen aus Oberen Yura und dem Wealden Norddeutschlands Geologie Yahrgang: v. 13, Heft 9.

Elsik, W. C., 1964. A new sporomorph genus from Eastern Peru: Pollen et Spores, v. 6, no. 2.

Groot, J. and Groot, C., 1962. Plant microfossils deposits from Aptian, Albian and Cenomanian of Portugal: Com. Serv. Geol. Portugal., v. 46.

Groot, J., Penny, J., and Groot, C., 1961. Plant microfossils and Age of the Raritan, Tuscaloosa and Magothy Formations of the Eastern United States: Palaeontographica, v. 108, Abt. B.

Hedlund, R. W. and Norris, G., 1968. Spores and pollen grains from Fredericksburgian (albian) strata Marshall country, Oklahoma; Pollen et Spores, v. 10, p. 1. 


\section{Z. KOTOVA}

Herngreen, G., 1973. Palynology of albian-cenomanian strata of borehole I-QS-I-MA, state of Maranhao, Brazil: Pollen et Spores, v. 15, no. 3-4.

1974. Middle Cretaceous palynomorphs from Northeastern Brazil: Sci. Geol., Bull., p. 27.

Jardiné, S., 1967. Spores á expansions en forme d'élateres du Crétacé moyen d'Afrique occidentale: Rev. Palaeob. Palyn., v. 1, p. 1-4.

Jardiné, S. and Magloire, L., 1965. Palynologie et stratigraphie du Crétacé des bassins du Sénégal et de Cote d'Ivoire: Mém. Bur. Rech. Géol. Minières, v. 32.

Jardiné, S., Doerenkamp, A. and Legoux, O., 1972. Le genre Hexaporotricolpites Boltenhagen 1967, morphologie, systématique, stratigraphie et extension geographique: Quatriéme Colloque Africain de Micropaléontologie.

Jardiné, S., Biens, P., and Doerenkamp A., 1974a. Dicheiropollis etruscus un pollen Caractéristique du crétacé Inférieur afro-sudamérican: Sci. Géol., Bull., v. 27.

Jardine, S., Kieser, G., and Reyre, Y., 1974 b. L'individulisation progressive du Continent Africain vue a Travers Les donnees Palynologiques de L'ere Secondaire: Sci. Géol., Bull., v. 27.

Kemp, E., 1970. Aptain and Albian miospores from Southern England: Paleontographica: Abt. B, v. 131, p. 1-4.
Krutzsch, 1959. Einige neue Formgattungen und-arten von Sporen und Pollen aus der mitteleuropäischen Oberk reide und dem Tertiar: Palaeontographica, Abt. B, v. 105.

Laing, J., 1975. Mid-Cretaceous angiosperm pollen from southern England and Northern France: Palaeontology, v. 18 , part 4 .

Muller, H., 1966. Palynological investigations of Cretaceous sediments in northeastern Brazil. In Hinte, J. E. (ed)., Second West African Micropaleontological Colloquium Proc., Ibadan, 1965: Brill (Leiden).

Muller, J., 1968. Palynology of the Pedawan and Plateau Sandstone Formation (Cretaceous-Eocene) in Sarawak, Malaysia: Micropaleontology, v. 14.

Reyre, J., 1966. Palynologie du Crétacé moyen du Sahara tunisien. Rev. Micropaleontology, v. 9, p. 1.

Stover, L. E., 1963. Some middle Cretaceous palynomorphs from West Africa: Micropaleontology, v. 9, p. 1. , 1964. Cretaceous ephedroid pollen from West Africa. Micropaleontology, v. 10, no. 2.

Trevisan, L., 1973. Peculiar structures connecting fossil pollen grains in pairs (Lower Cretaceous sediments of Southern Tuscuny), Italy. Morphology and systematics of fossil pollen and spores: Internatl. Palynol. Conf. Proc., Nauka.

Van Ameron, H., 1965. Upper-Cretaceous pollen and spores assemblages from the so-called "Wealden" of the Province of Leon (Northern Spain): Pollen et Spores, v. 7, No. 1. 

PLATE 1

Magnification $\times 600$

Figure $1 \quad$ Cyathidites minor Couper, 1953.

Morocco Basin, 370-41, CC.

Cenomanian.

Figure $2 \quad$ Cyathidites australis Couper, 1953.

Morocco Basin, 370-41, CC,

Neocomian.

Figure $3 \quad$ Cyathidites australis.

Cape Verde Basin, 367-23, CC,

Cenomanian.

Figure $4 \quad$ Matonisporites sp.

Morocco Basin, 370-32, CC,

Aptian-?lower Albian.

Figure $5 \quad$ Stereisporites antiquasporites (Wilson and

Webster) Dettmann, 1963.

Morocco Basin, 370-32, CC,

Aptian-?lower Albian.

Figure $6 \quad$ Leptolepidites verrucatus Couper, 1953.

Morocco Basin, 370-27, CC,

Cenomanian.

Figures 7,8 Leptolepidites verrucatus.

Morocco Basin, 370-32, CC,

Aptian-?lower Albian.

Figure 9 Concavissimisporites veriverrucatus (Couper)

Brenner, 1963.

Morocco Basin, 370-41, CC,

Neocomian.

Figures 10,11 Concavissimisporites sp.

Morocco Basin, 370-41, CC,

Neocomian.

Figure 12 Tuberositriletes montuosus Doring, 1964.

Morocco Basin, 370-41, CC,

Neocomian.

Figure $13 \quad$ Verrucosisporites $\mathrm{sp}$.

Cape Verde Basin, 367-23, CC,

Cenomanian.

Figure $14 \quad$ Verrucosisporites sp.

Morocco Basin, 370-30, CC,

upper Albian-lower Cenomanian.

Figure $15 \quad$ Ceratosporites parvus Brenner, 1963.

Morocco Basin, 370-41, CC,

Neocomian.

Figure 16 Cicatricosisporites proxiradiatus Kemp, 1970.

Morocco Basin, 370-27, CC,

Cenomanian.

Figure 17 Cicatricosisporites venustus Deak, 1963.

Morocco Basin, 370-32, CC,

Aptian-?lower Albian.

Figure 18 Cicatricosisporites microstriatus Jardiné and Magloire, 1965.

Morocco Basin, 370-41, CC,

Neocomian. 
PLATE 1
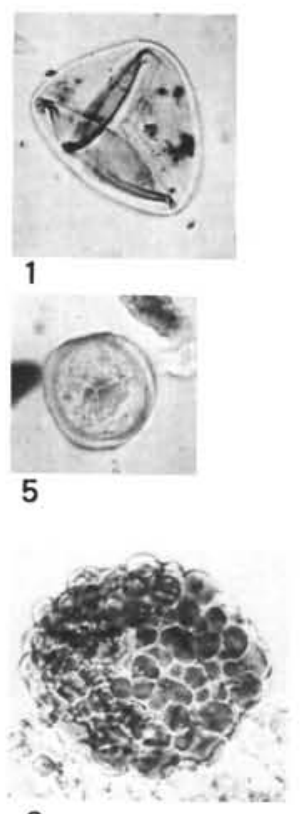

6
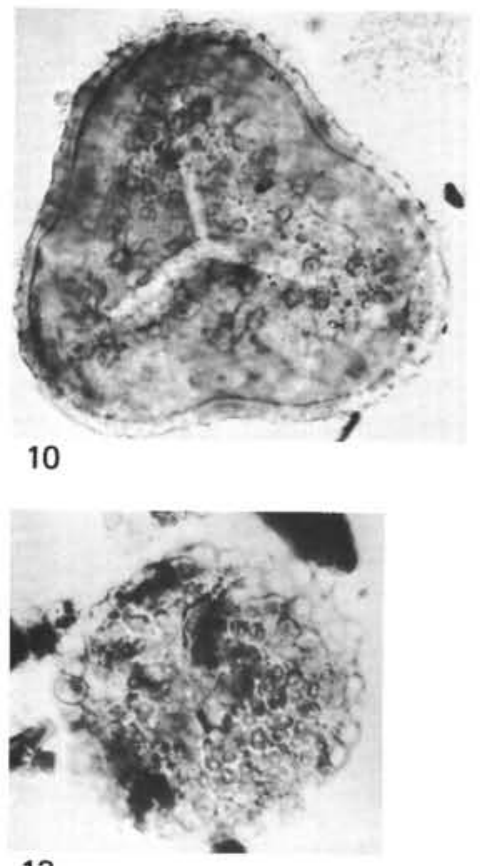

13
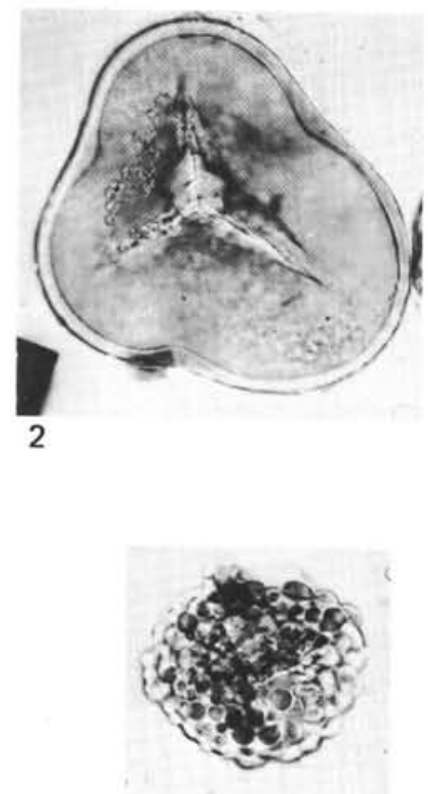

7

11
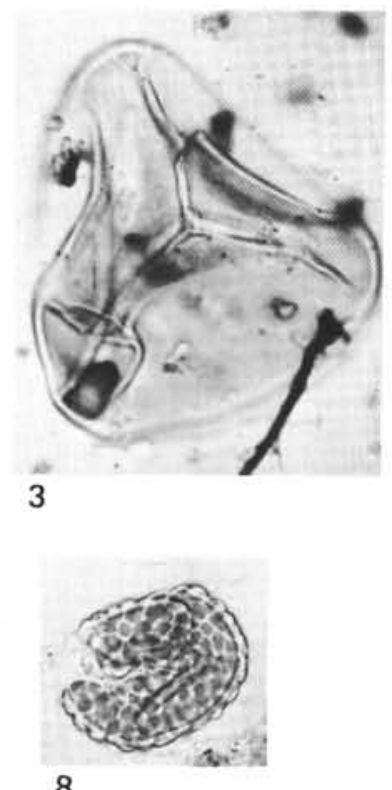

8
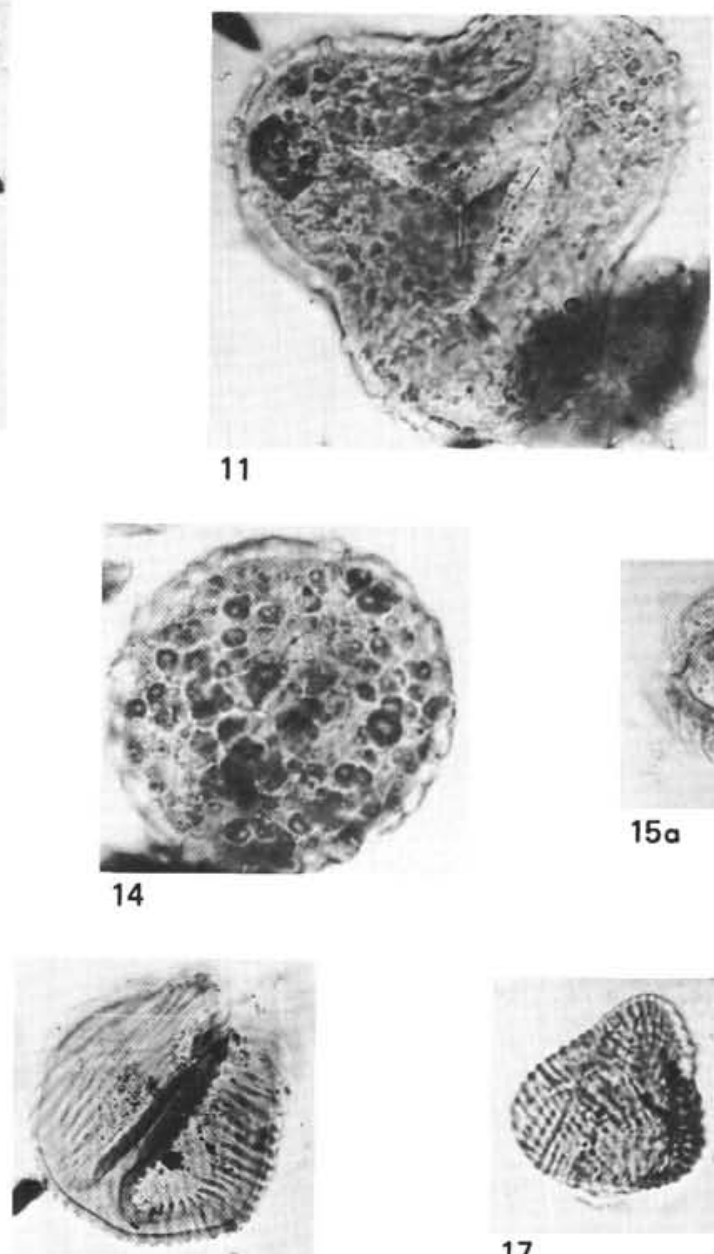

$16 b$

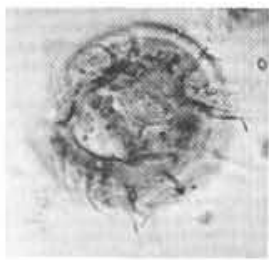

$15 a$

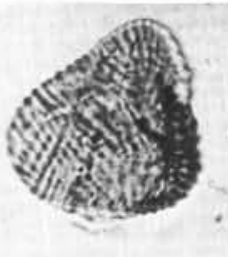

17
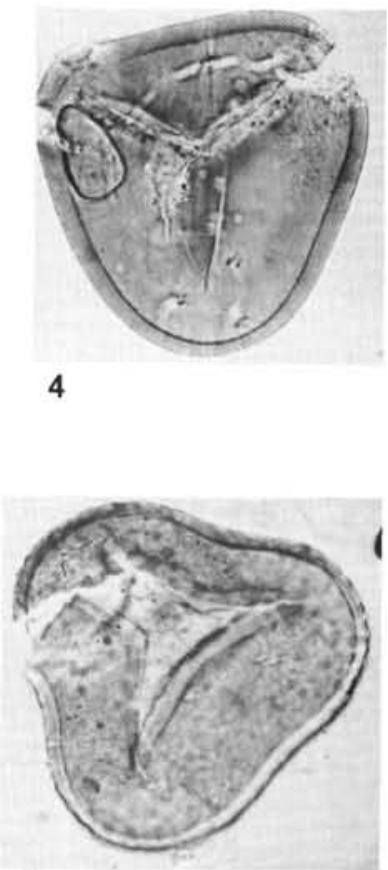

9

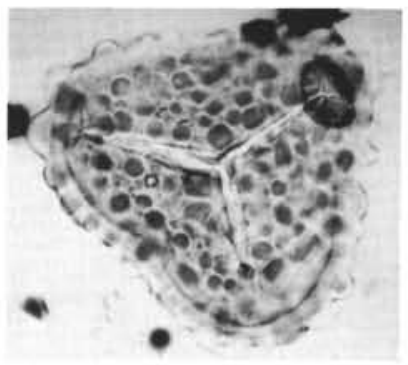

12

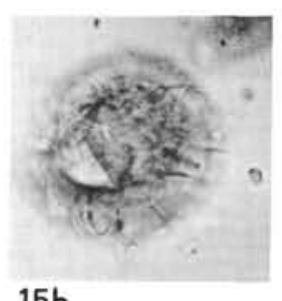

$15 b$

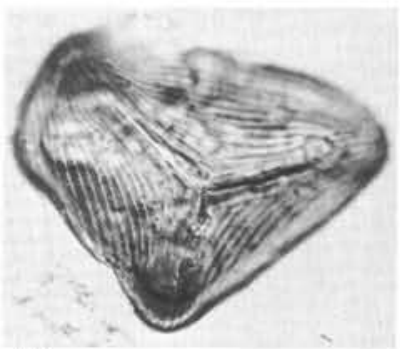

18 


\section{PLATE 2}

Magnification $\times 600$

Figures 1-3 Cicatricosisporites brevilaesuratus Couper, 1958. Morocco Basin, 370-41, CC, Neocomian.

Figures 4, $5 \quad$ Cicatricosisporites $\mathrm{sp} .1$. Morocco Basin, 370-41, CC, Neocomian.

Figure $6 \quad$ Cicatricosisporites $\mathrm{sp} .2$. Morocco Basin, 370-41, CC, Neocomian.

Figure 7 Cicatricosisporites potomacensis Brenner, 1963. Cape Verde Basin, 367-21, CC, Cenomanian.

Figure $8 \quad$ Cicatricosisporites sp. 3. Morocco Basin, 370-31, CC, upper Albian-lower Cenomanian. 


\section{PLATE 2}

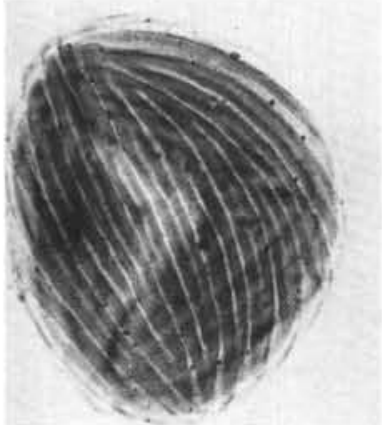

$1 a$

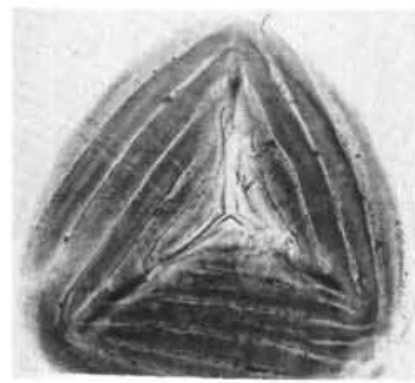

$2 a$

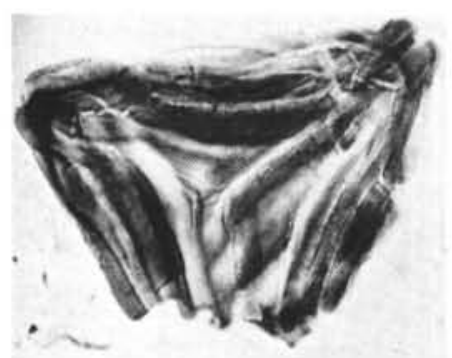

$4 a$

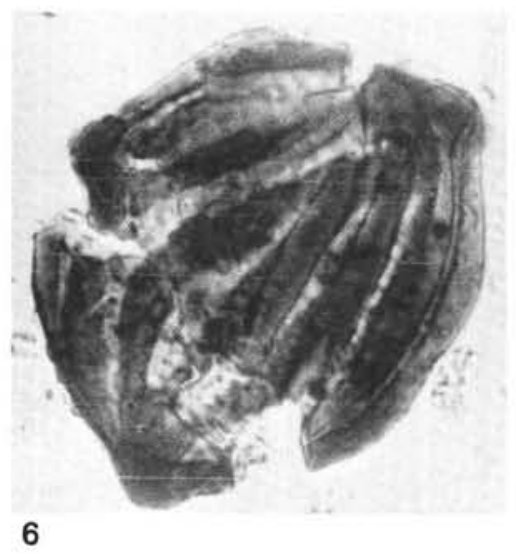

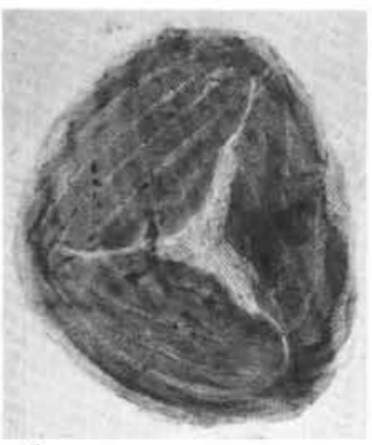

$1 b$
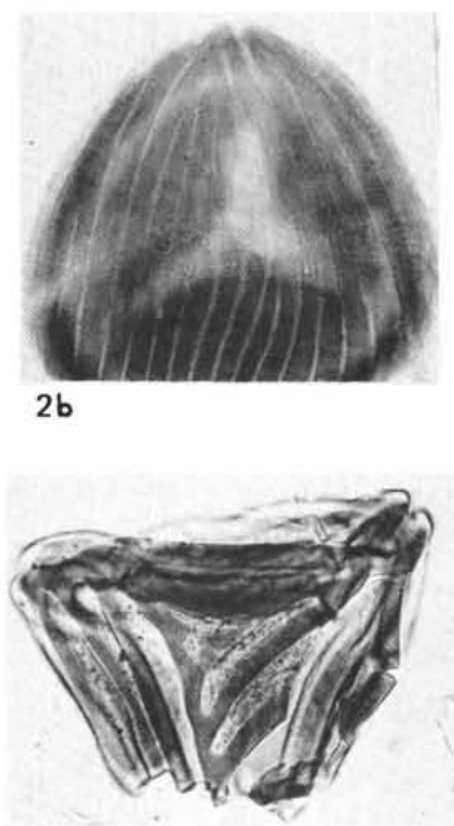

$4 b$
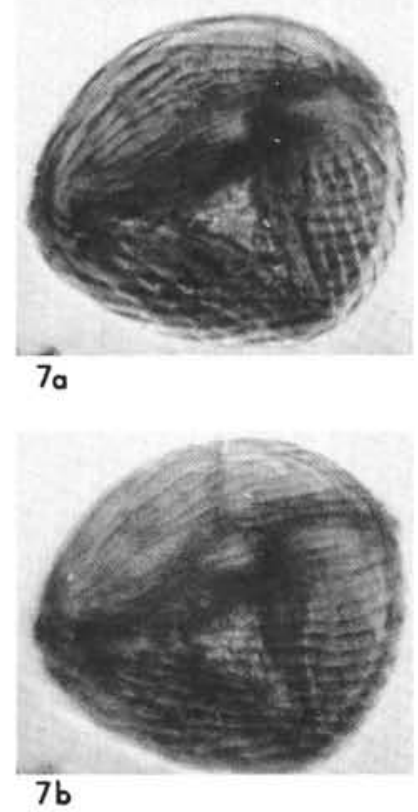

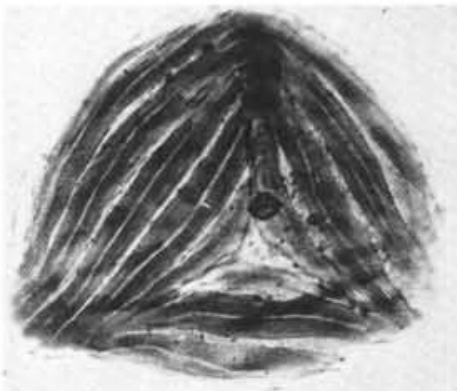

$3 a$

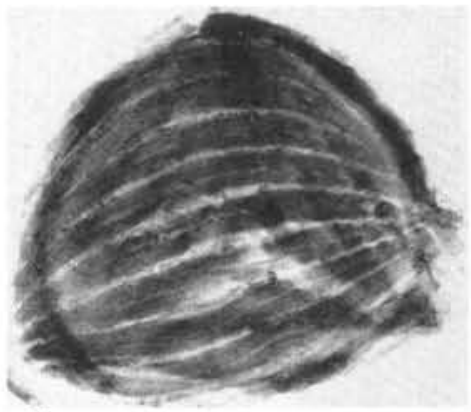

3b

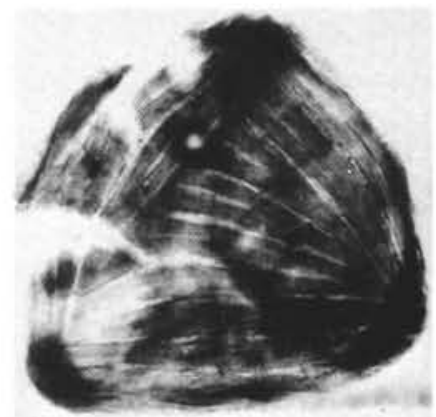

$5 a$

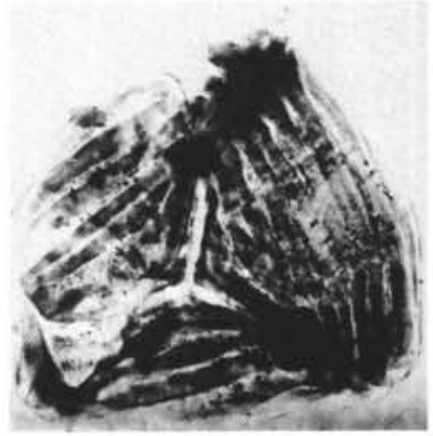

$5 b$

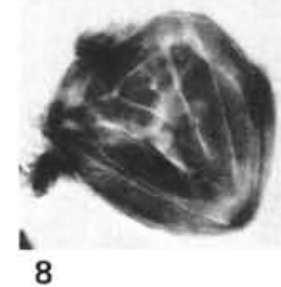


PLATE 3

Magnification $\times 600$

Figures 1,2 Cicatricosisporites sp. 4.

Morocco Basin, 370-27, CC,

Cenomanian.

Figures 3, $4 \quad$ Cicatricosisporites sp. 5.

Morocco Basin, 370-32, CC, Aptian-?lower Albian.

Figures 5,6 Appendicisporites sp. 1 .

Morocco Basin, 370-32, CC.

Aptian-?lower Albian.

Figure 7 Appendicisporites sp. 2.

Morocco Basin, 370-32, CC,

Aptian-?lower Albian.

Figure $8 \quad$ Appendicisporites sp. 3 .

Cape Verde Basin, 367-23, CC,

Cenomanian.

Figures 9, 10 Gleicheniidites senonicus Ross, 1949.

Morocco Basin, 370-41, CC,

Neocomian.

Figure $11 \quad$ Gleicheniidites senonicus.

Morocco Basin, 370-27, CC,

Cenomanian.

Figures 12,13 Gleicheniidites senonicus.

Morocco Basin, 370-32, CC,

Aptian-lower Albian.

Figures 14, 15 Reticulatasporites jardinus Brenner, 1968.

Morocco Basin, 370-27, CC,

Cenomanian. 


\section{PLATE 3}

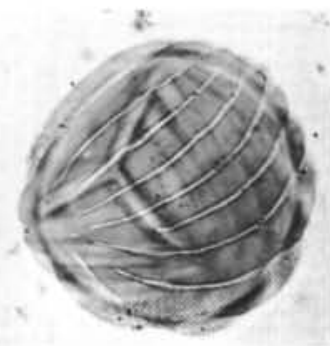

1a

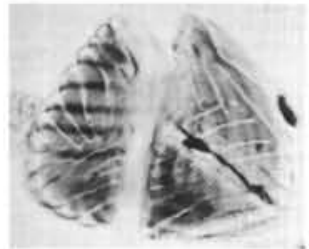

$3 a$

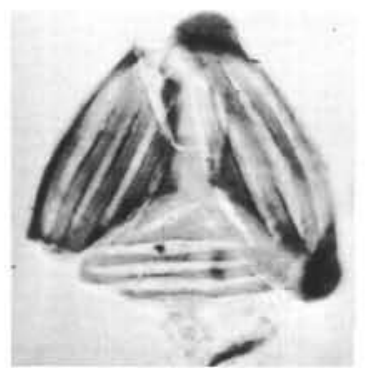

$5 a$

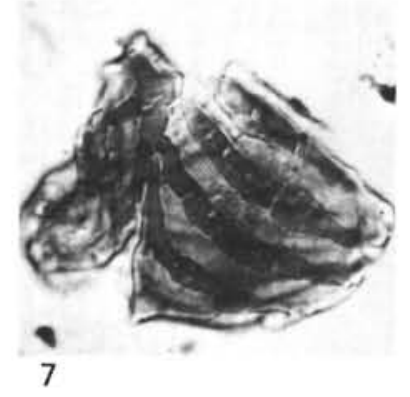

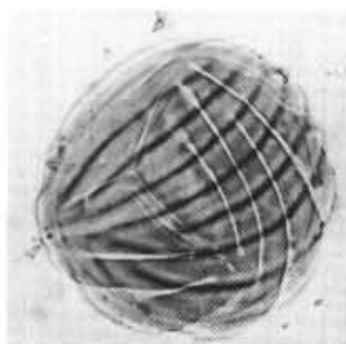

$1 b$

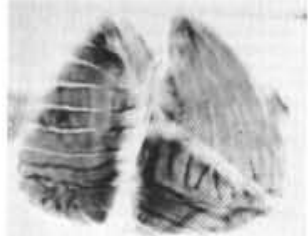

$3 b$
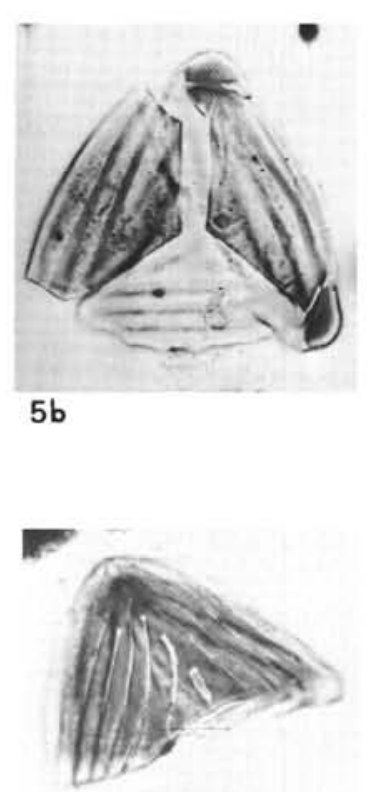

$8 a$

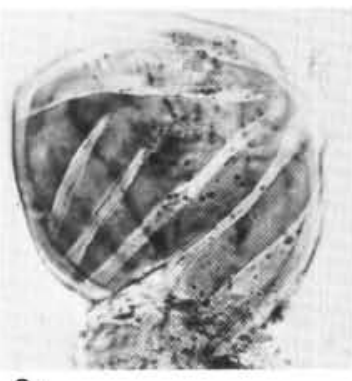

$2 a$
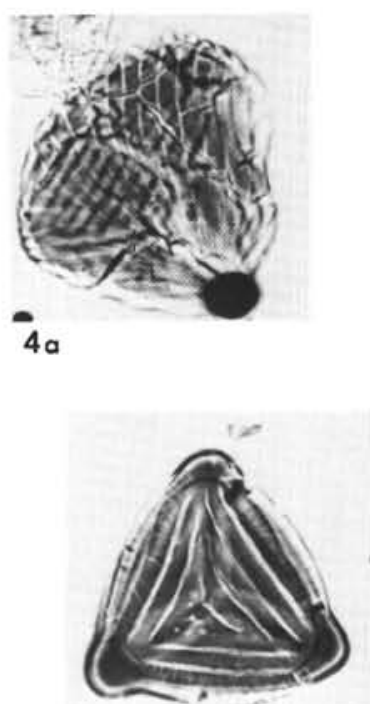

$6 a$

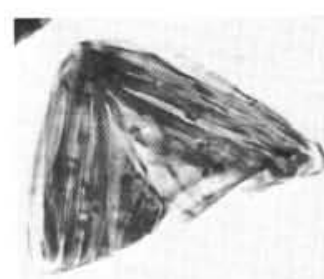

$8 b$
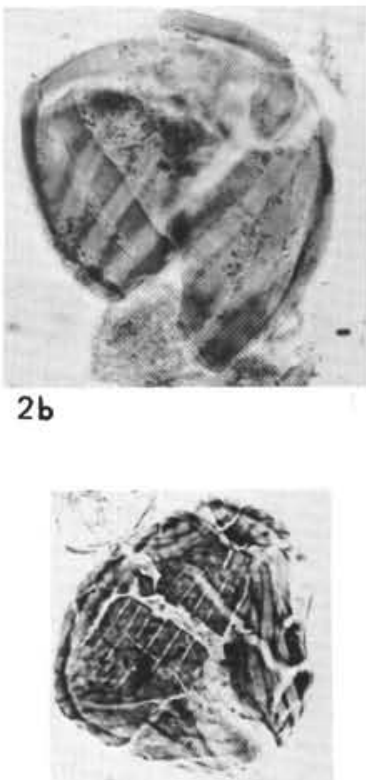

$4 b^{-}$

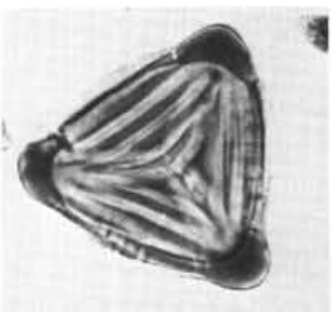

$6 b$

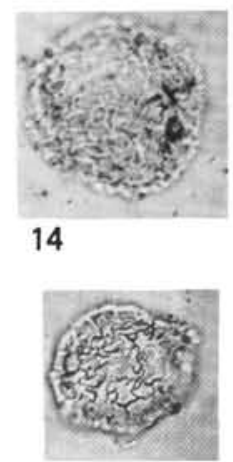

15

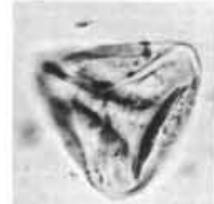

9

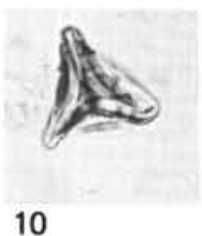

10

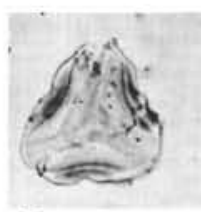

11

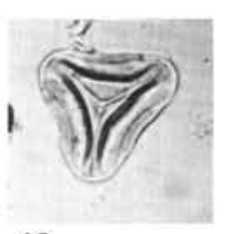

12

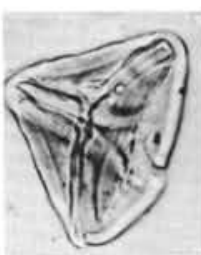

13 
PLATE 4

Magnification $\times 600$

Figure 1 Coronatispora valdensis (Couper) Dettmann, 1963.

Morocco Basin, 370-32, CC,

Aptian-?lower Albian.

Figure 2 Klukisporites $\mathrm{sp}$.

Morocco Basin, 370-41, CC,

Neocomian.

Figure $3 \quad$ Klukisporites $\mathrm{sp}$.

Morocco Basin, 370-32, CC,

Aptian-?lower Albian.

Figure 4 Corrugatisporites ivoirensis Jardiné and Magloire, 1965.

Cape Verde Basin, 367-23, CC,

Cenomanian.

Figures 5,6 Perotrilites pannuceus Brenner, 1963.

Cape Verde Basin, 367-23, CC,

Cenomanian.

Figure 7 Coptospora sp.

Cape Verde Basin, 367-23, CC, Cenomanian.

Figures 8-10 Patellasporites distaverrucosus (Brenner) Kemp, 1970.

Cape Verde Basin, 367-23, CC,

Cenomanian.

Figure $11 \quad$ Patellasporites distaverrucosus.

Morocco Basin, 370-41, CC,

Neocomian.

Figure 12 Reticulatisporites sp. 1.

Cape Verde Basin, 367-23, CC,

Cenomanian.

Figures 13-15 Reticulatisporites sp. 2.

Cape Verde Basin, 367-23, CC, Cenomanian. 


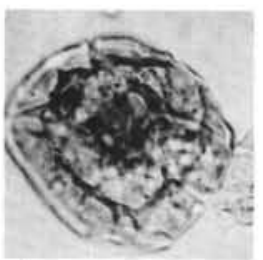

$1 a$

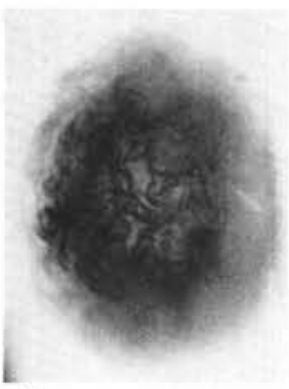

5
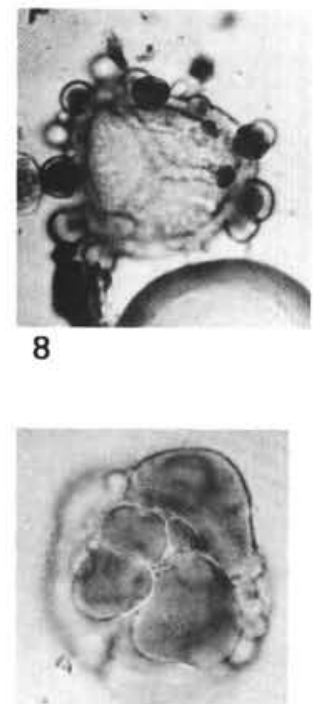

$11 a$

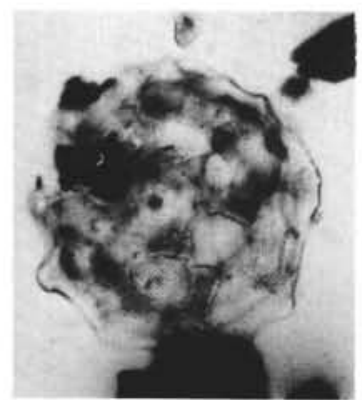

$14 a$

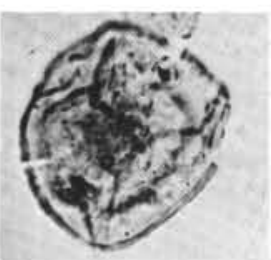

$1 \mathrm{~b}$

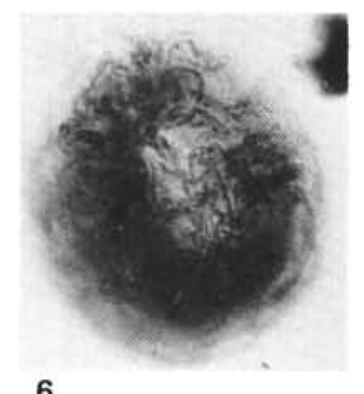

6
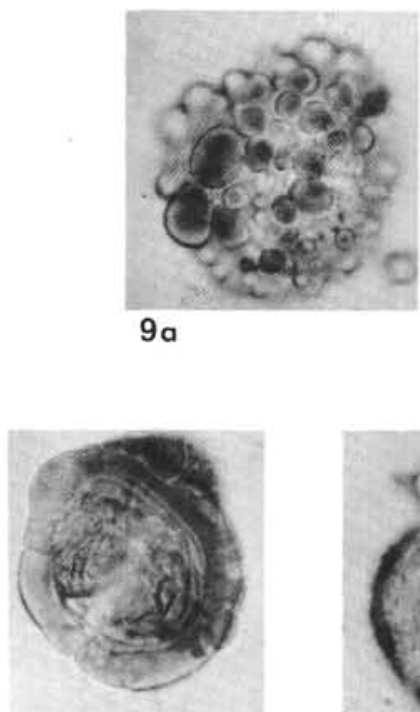

$11 \mathrm{~b}$

\section{PLATE 4}

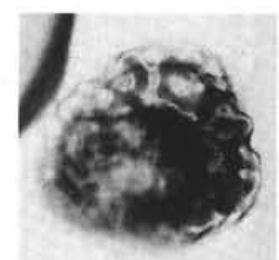

2

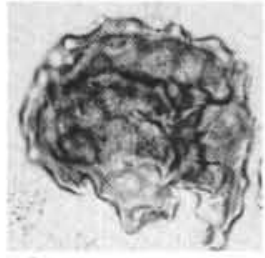

3

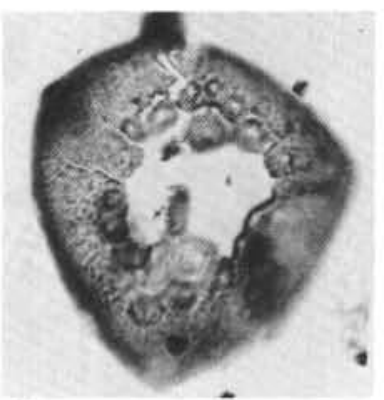

$7 a$
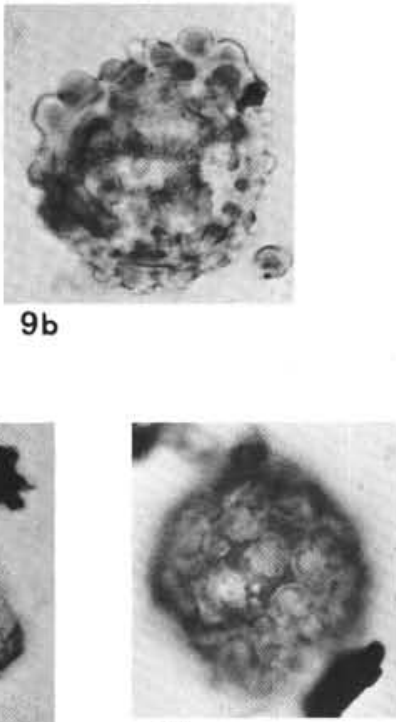

$13 a$

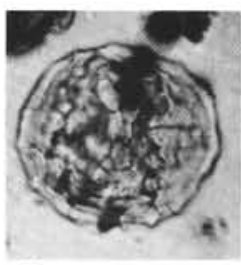

4

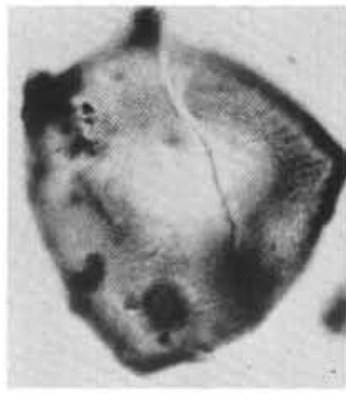

$7 b$
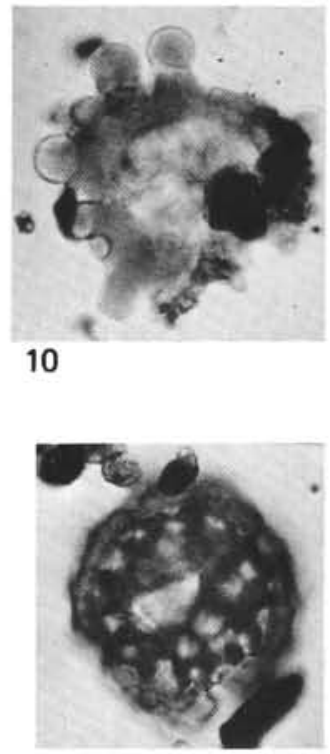

$13 b$
12

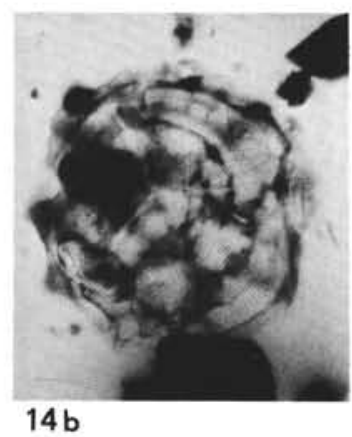

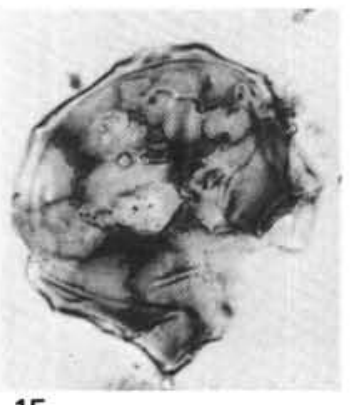

$15 a$

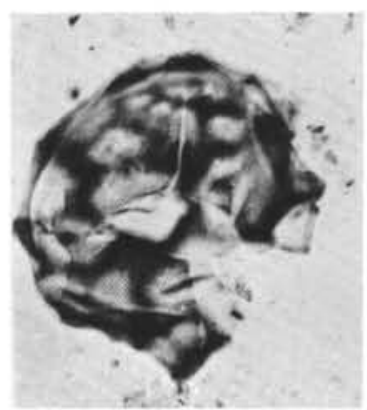

$15 b$ 
PLATE 5

Magnification $\times 600$

Figures 1-3 Elaterosporites klaszi. (Jardiné and Magloire) Jardiné, 1967.

Cape Verde Basin, 367-21, CC,

Cenomanian.

Figures 4, $5 \quad$ Elaterosporites klaszi.

Cape Verde Basin, 367-23, CC,

Cenomanian.

Figure 6 Galeacornea cf. causea Stover, 1963.

Cape Verde Basin, 367-23, CC,

Cenomanian.

Figure $7 \quad$ Elaterosporites $\mathrm{sp}$.

Cape Verde Basin, 367-23, CC,

Cenomanian

Figures 8,9 Elaterocolpites sp.

Cape Verde Basin, 367-21, CC,

Cenomanian.

Figures 10-12 ?Galeacornea sp.

Cape Verde Basin, 367-21, CC,

Cenomanian.

Figure 13 ?Galeacornea $\mathrm{sp}$.

Morocco Basin, 370-29, CC,

upper Albian-lower Cenomanian. 
PLATE 5

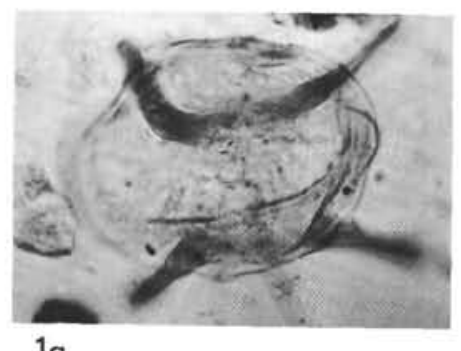

$1 a$

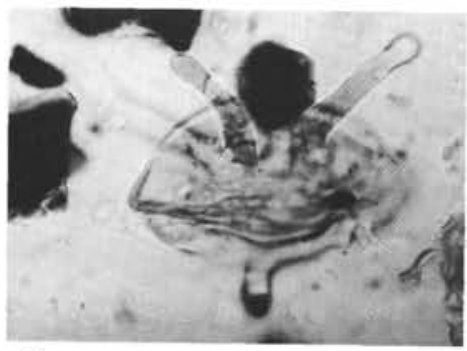

3

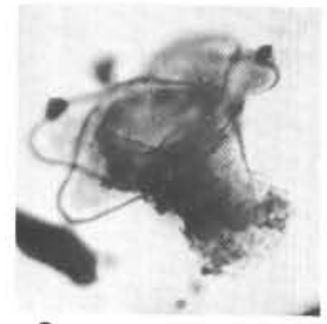

6

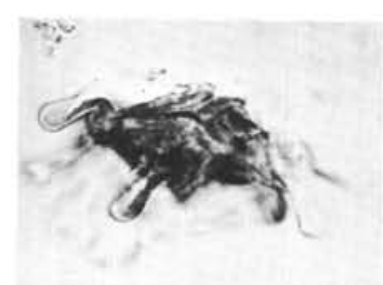

$8 a$
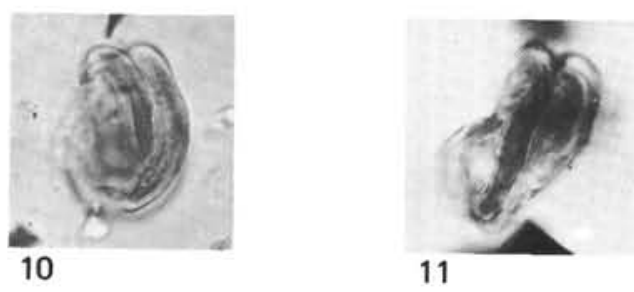

$7 a$
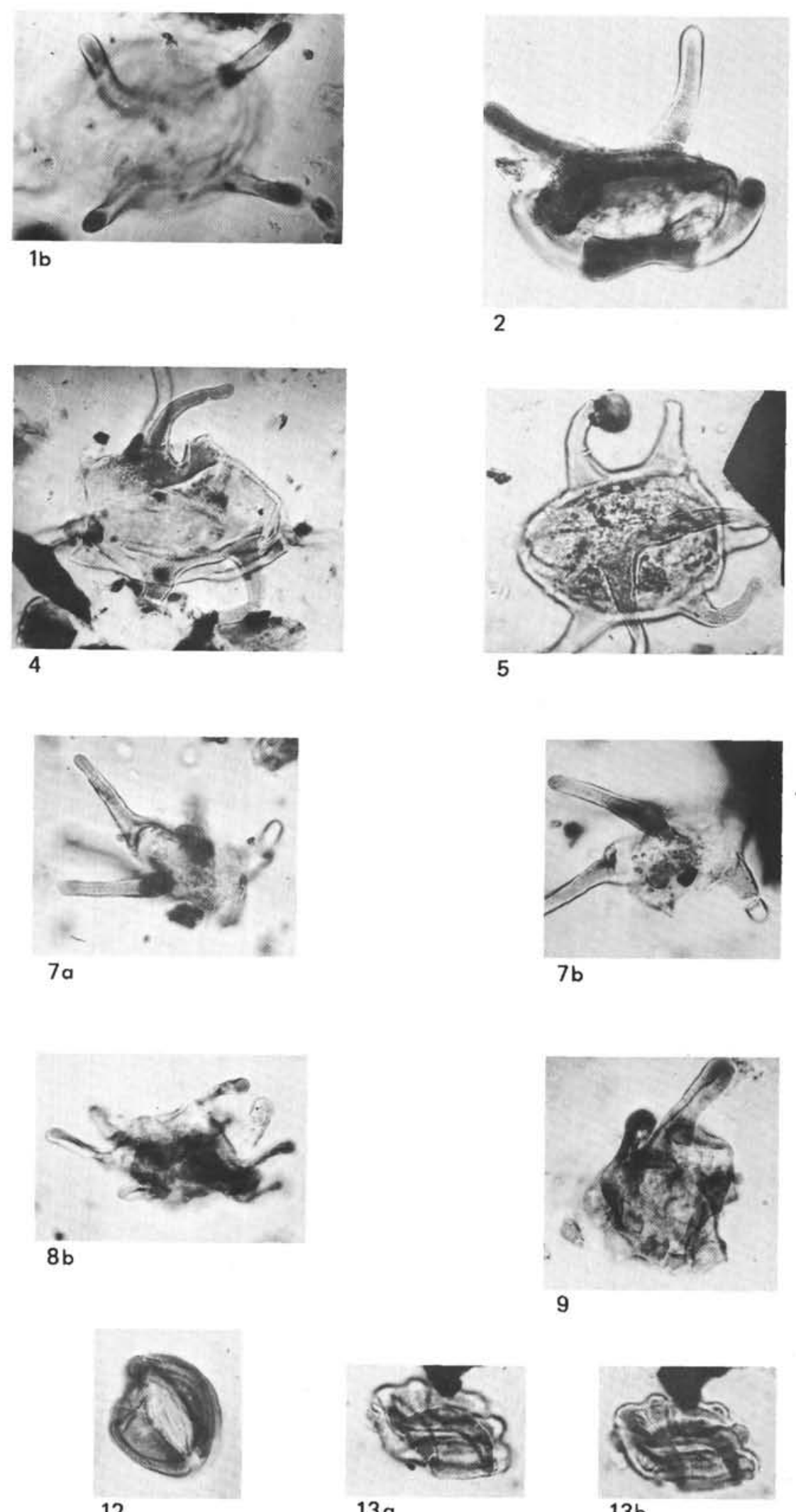

$13 a$

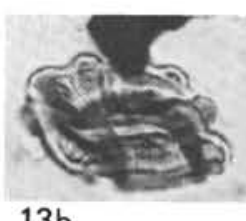


PLATE 6

Magnification $\times 600$

Figures 1,2 Ephedripites multicostatus Brenner, 1963.

Morocco Basin, 370-41, CC,

Neocomian.

Figures 3-5 Ephedripites multicostatus.

Morocco Basin, 370-32, CC,

Aptian-?lower Albian.

Figures 6,7 Ephedripites sp. 5.

Morocco Basin, 370-27, CC,

Cenomanian.

Figures 8-12 Ephedripites sp. 1.

Cape Verde Basin, 367-23, CC,

Cenomanian.

Figures 13,14 Ephedripites sp. 1.

Morocco Basin, 370-41, CC,

Neocomian.

Figures 15-18 Ephedripites sp. 2.

Morocco Basin, 370-41, CC,

Neocomian.

Figures 19-26 Ephedripites sp. 3.

Morocco Basin, 370-27, CC,

Cenomanian. 


\section{PLATE 6}
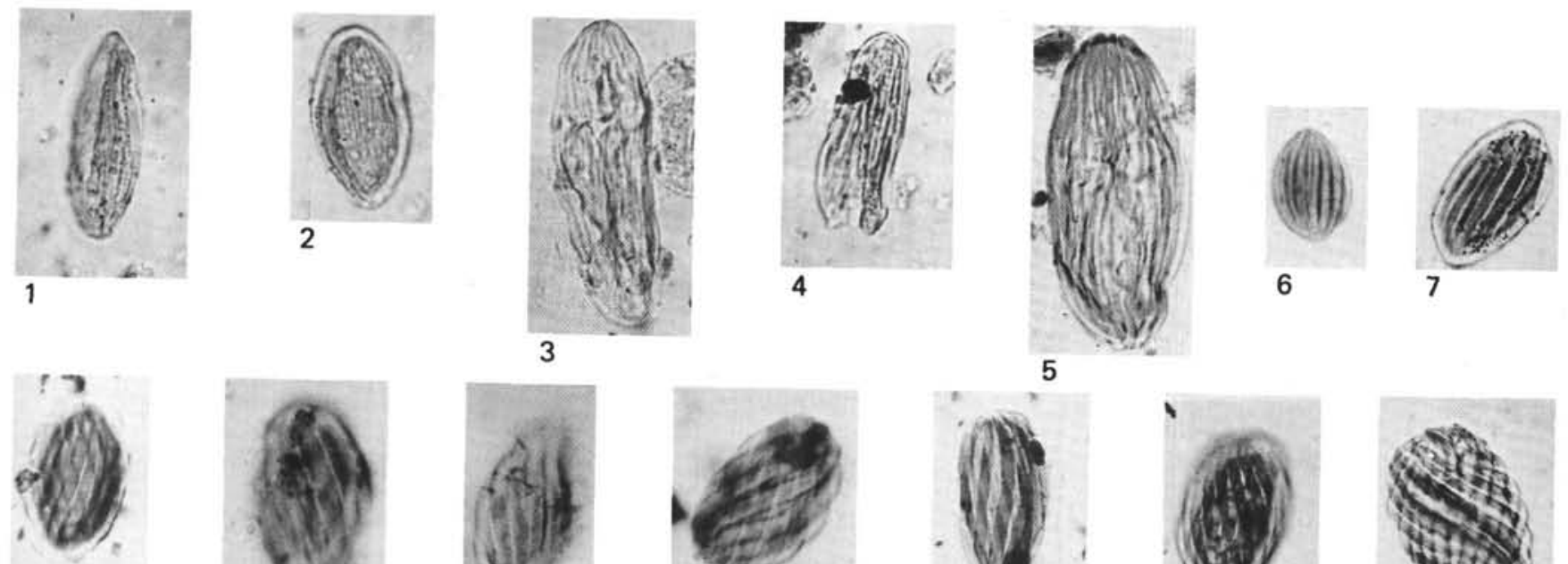

8
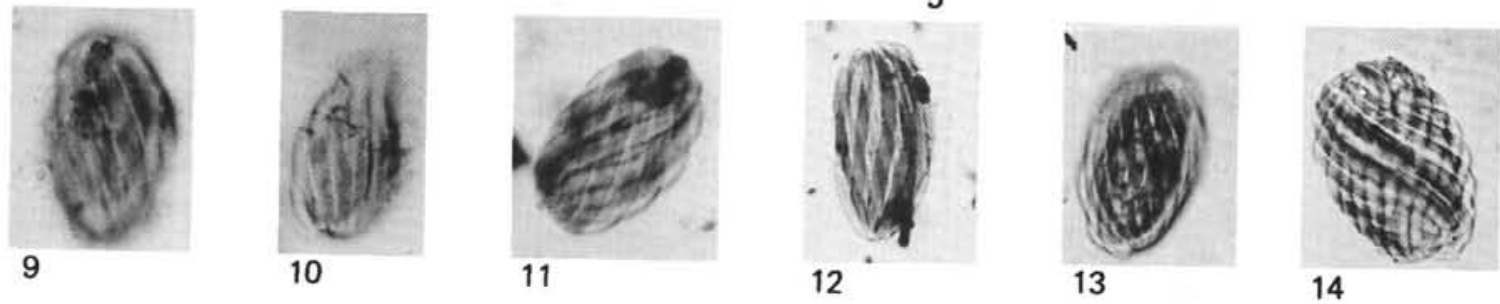

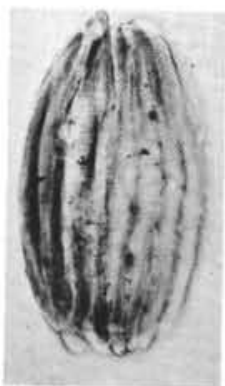

$15 a$
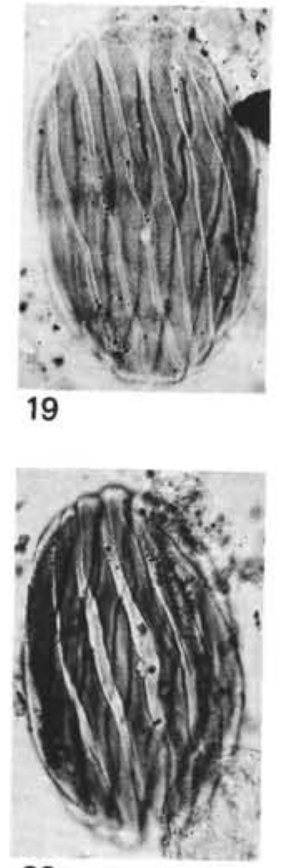

23

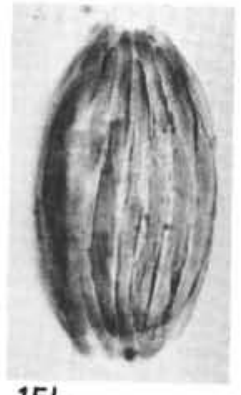

$15 b$
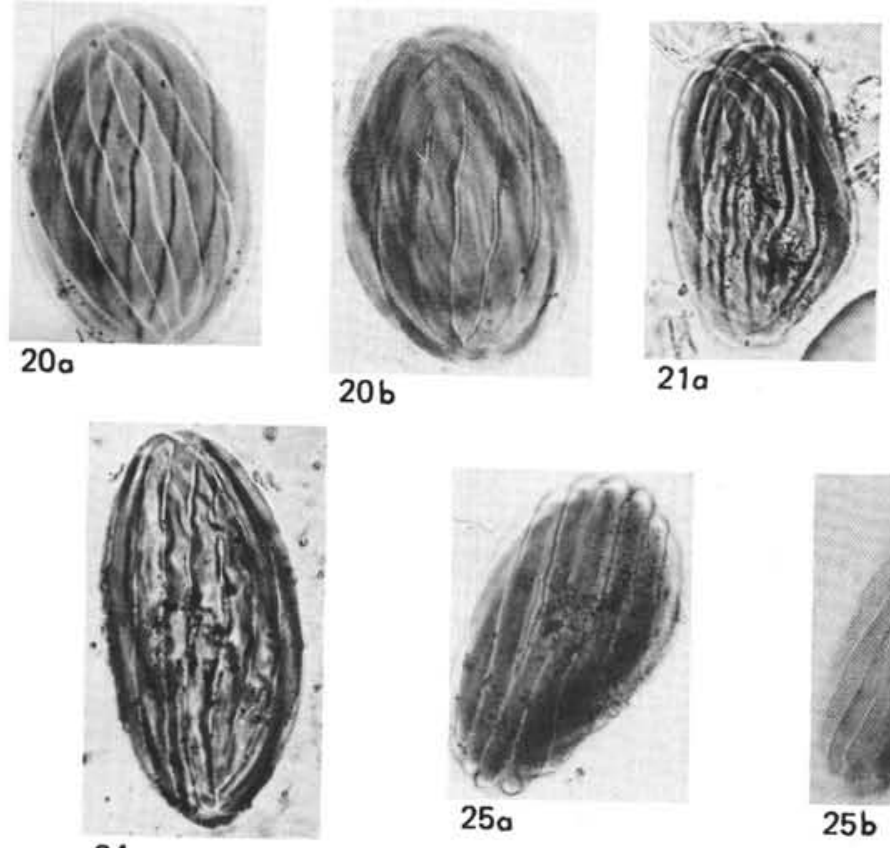

24

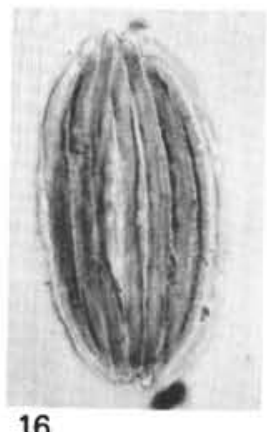

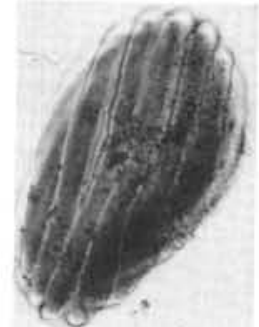

25a

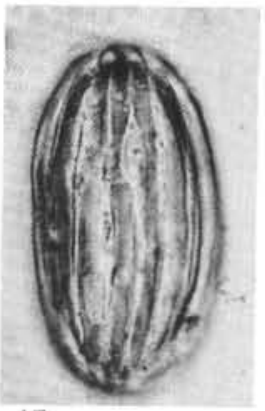

17
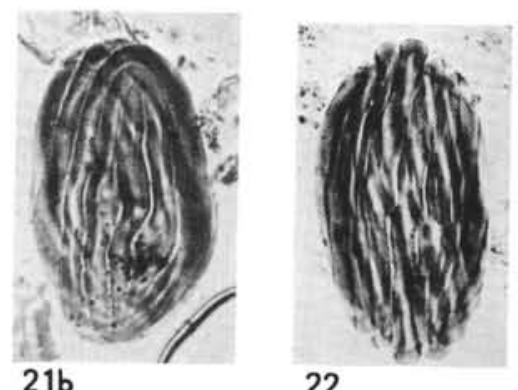

22

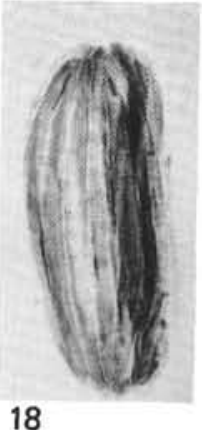

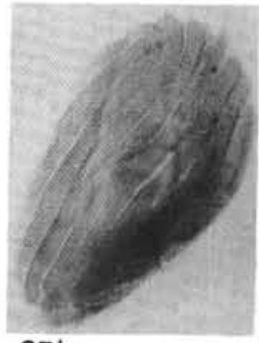

$25 b$

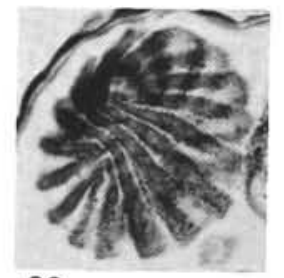

26 
PLATE 7

Magnification $\times 600$

Figures 1-5 Ephedripites jansonii (Pocock) Muller, 1968.

Morocco Basin, 370-27, CC,

Cenomanian.

Figures 6,7 Ephedripites sp. 4.

Morocco Basin, 370-27, CC,

Cenomanian.

Figures 8,9 Ephedripites pentacostatus Brenner, 1968.

Cape Verde Basin, 367-23, CC,

Cenomanian.

Figures 10-12 Steevesipollenites binodosus Stover, 1964.

Cape Verde Basin, 367-23, CC,

Cenomanian.

Figures 13,14 Steevesipollenites binodosus.

Morocco Basin, 370-27, CC,

Cenomanian.

Figure $15 \quad$ Steevesipollenites sp. 1.

Morocco Basin, 370-41, CC,

Neocomian.

Figures 16,17 Steevesipollenites sp. 1.

Morocco Basin, 370-32, CC,

Aptian-?lower Albian.

Figure 18 Steevesipollenites dajani Brenner, 1968.

Cape Verde Basin, 367-23, CC,

Cenomanian.

Figure $19 \quad$ Steevesipollenites $\mathrm{sp} .3$.

Cape Verde Basin, 367-23, CC,

Cenomanian.

Figure $20 \quad$ Steevesipollenites sp. 4.

Cape Verde Basin, 367-23, CC,

Cenomanian.

Figure $21 \quad$ Steevesipollenites $\mathrm{sp} .5$.

Morocco Basin, 370-27, CC,

Cenomanian.

Figure $22 \quad$ Ephedripites sp. 7.

Cape Verde Basin, 367-23, CC,

Cenomanian. 


\section{PLATE 7}
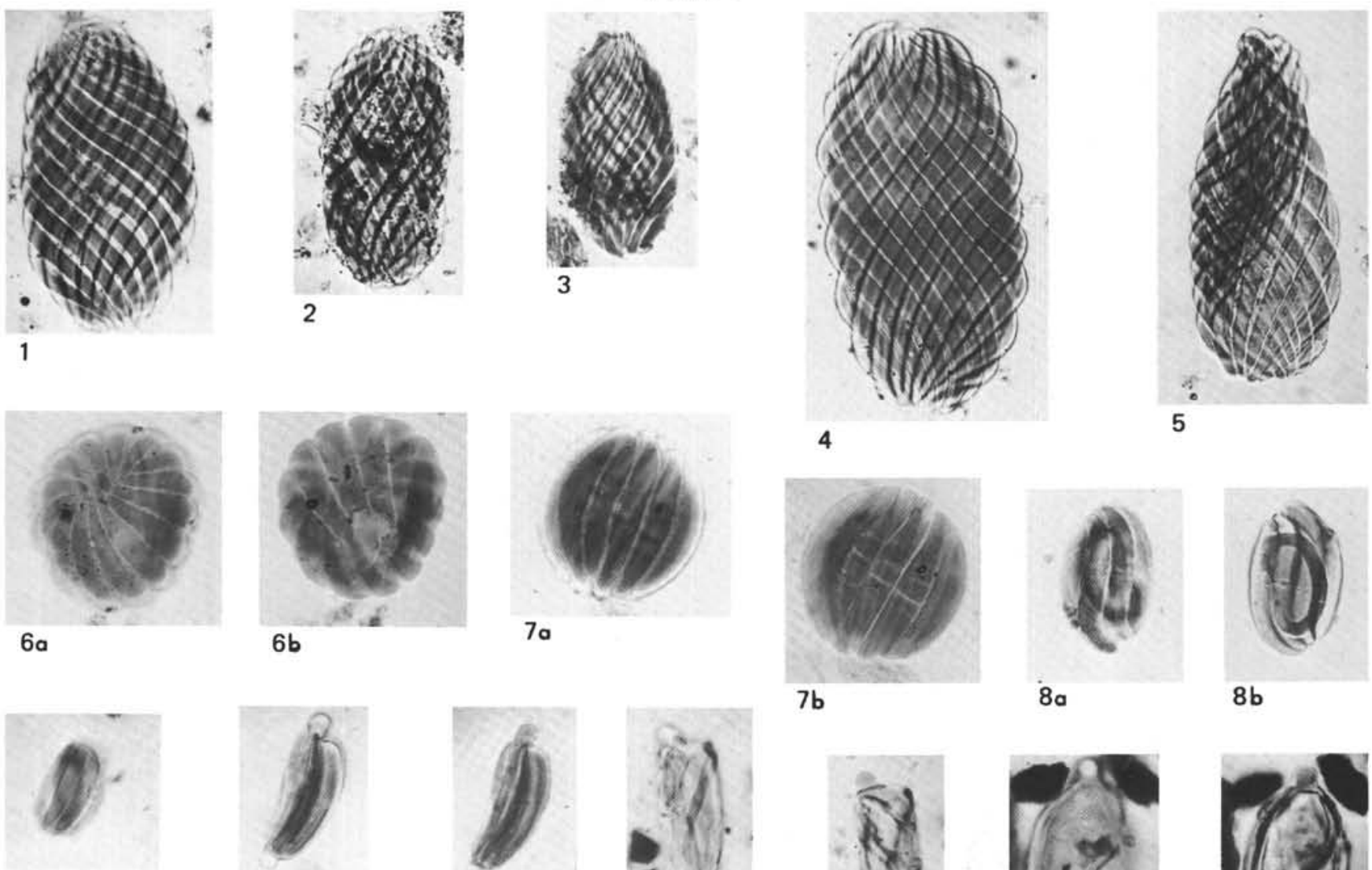

9
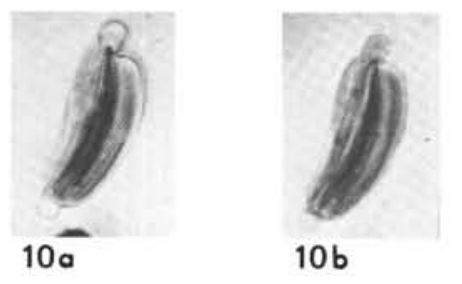
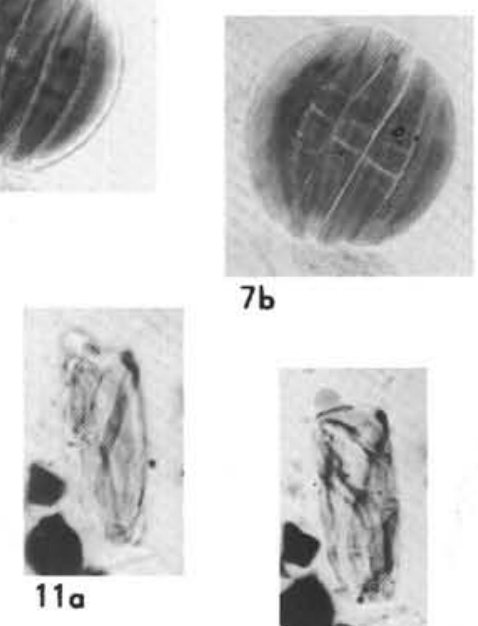

$7 b$
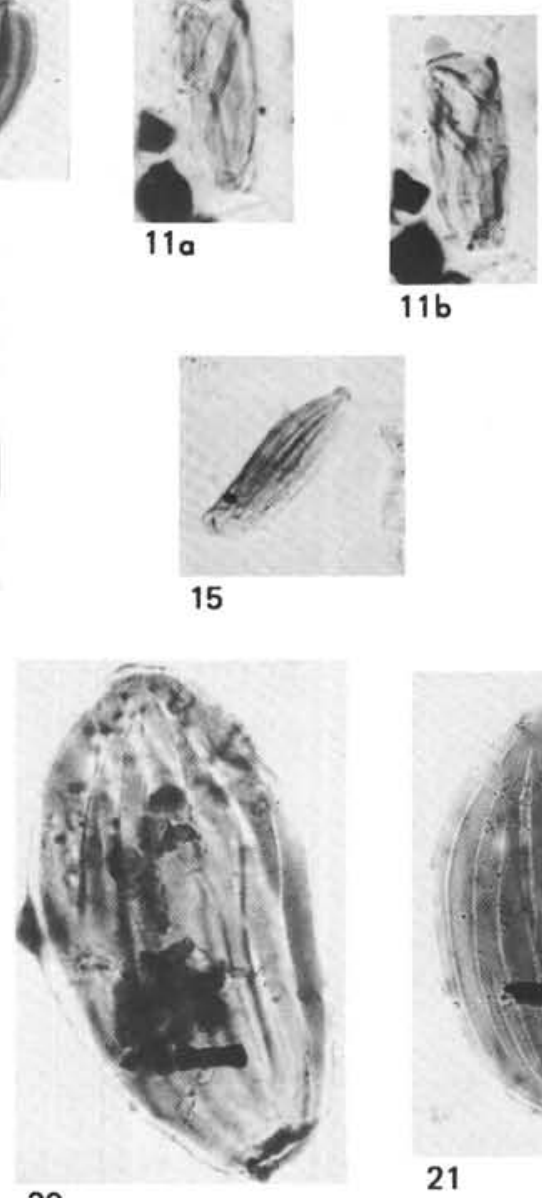

20

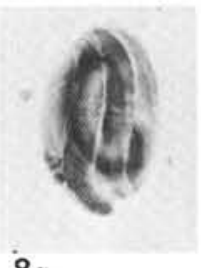

$8 a$

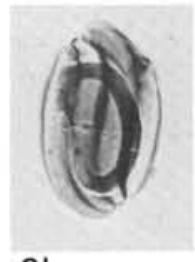

$8 b$

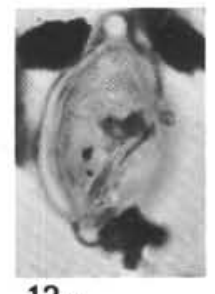

$12 a$
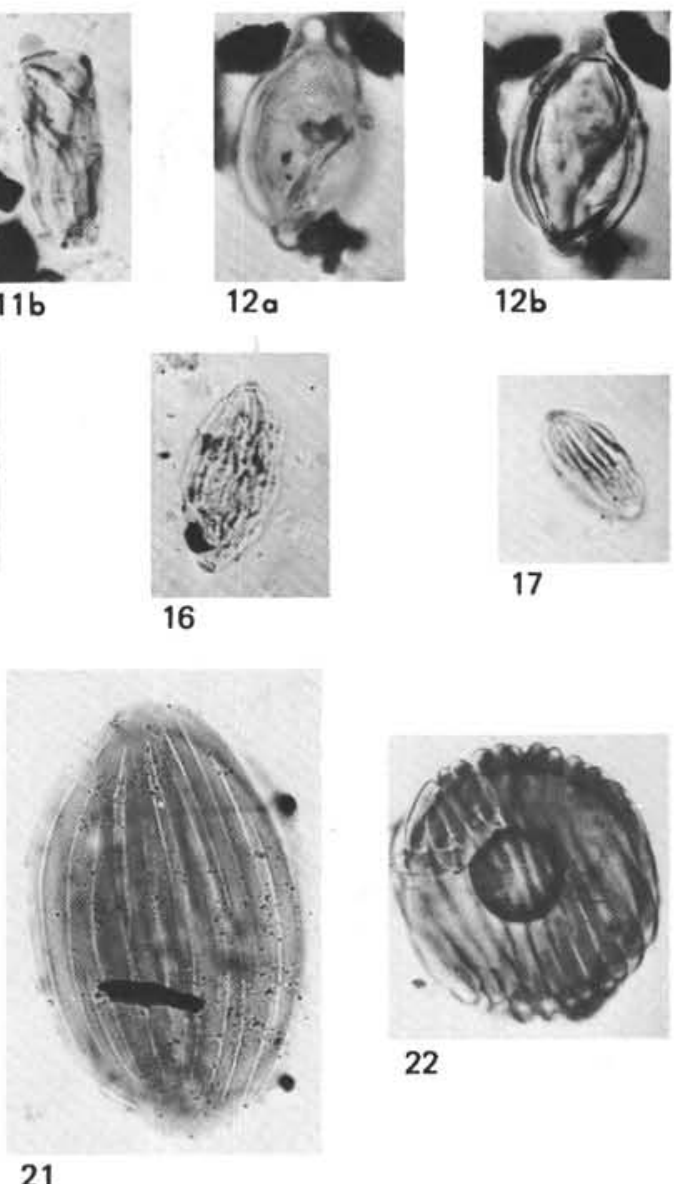

22 


\section{PLATE 8}

Magnification $\times 600$

Figures 1-4 Steevesipollenites sp. 6.

Cape Verde Basin, 367-23, CC, Cenomanian.

Figures 5,6 Steevesipollenites sp. 7. Morocco Basin, 370-27, CC, Cenomanian.

Figures 7-9 Steevesipollenites sp. 8. Morocco Basin, 370-27, CC, Cenomanian.

Figures 10-12 Steevesipollenites sp. 8a. Morocco Basin, 370-41, CC, Neocomian.

Figures 13-14 Steevesipollenites sp. 9. Morocco Basin, 370-27, CC, Cenomanian.

Figures 15-16 Steevesipollenites sp. 10.

Cape Berde Basin, 367-23, CC, Cenomanian.

Figures 17, 18 Steevesipollenites sp. 10. Morocco Basin, 370-27, CC, Cenomanian. 
PLATE 8

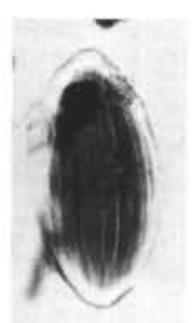

1
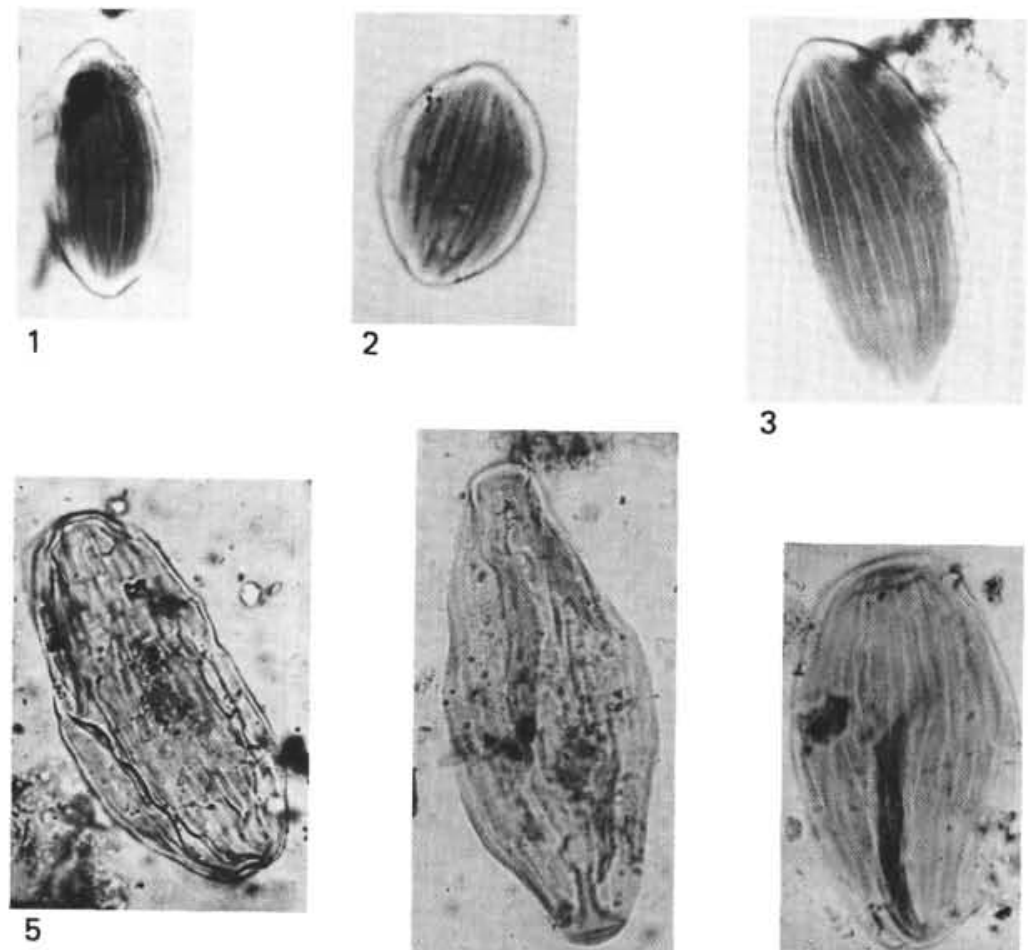

3
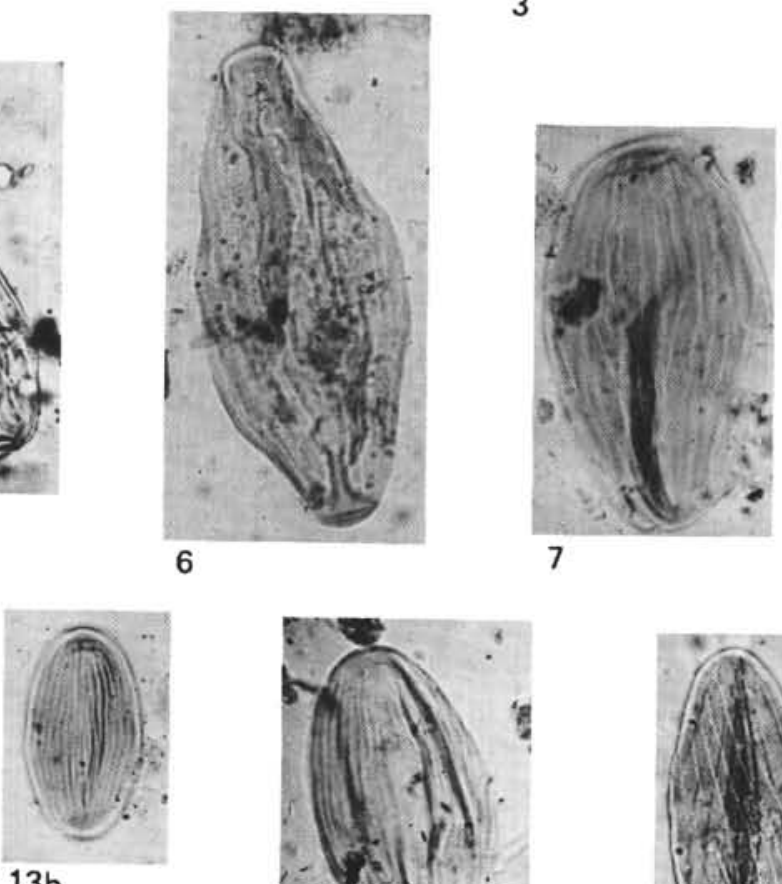

$13 a$

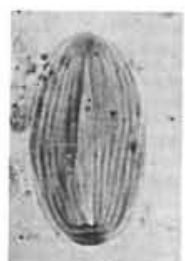

$13 b$
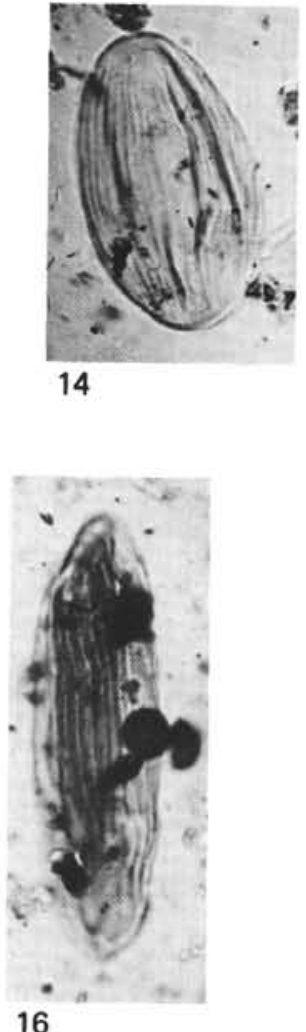

15

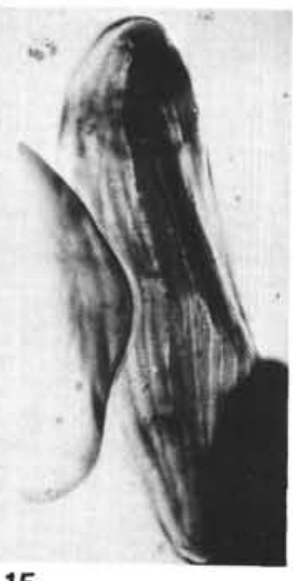

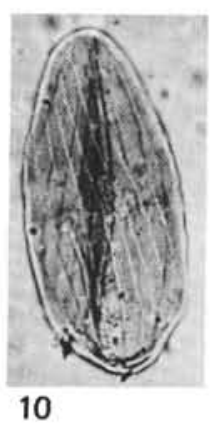

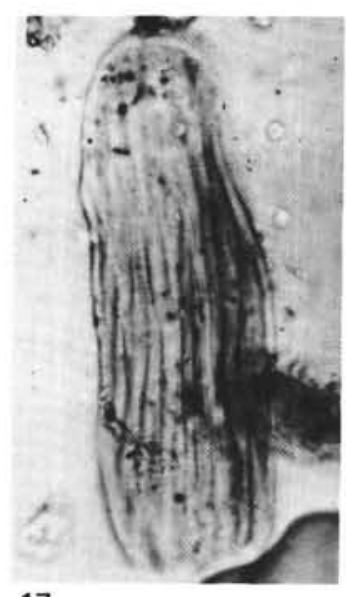

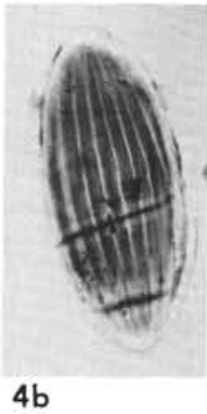
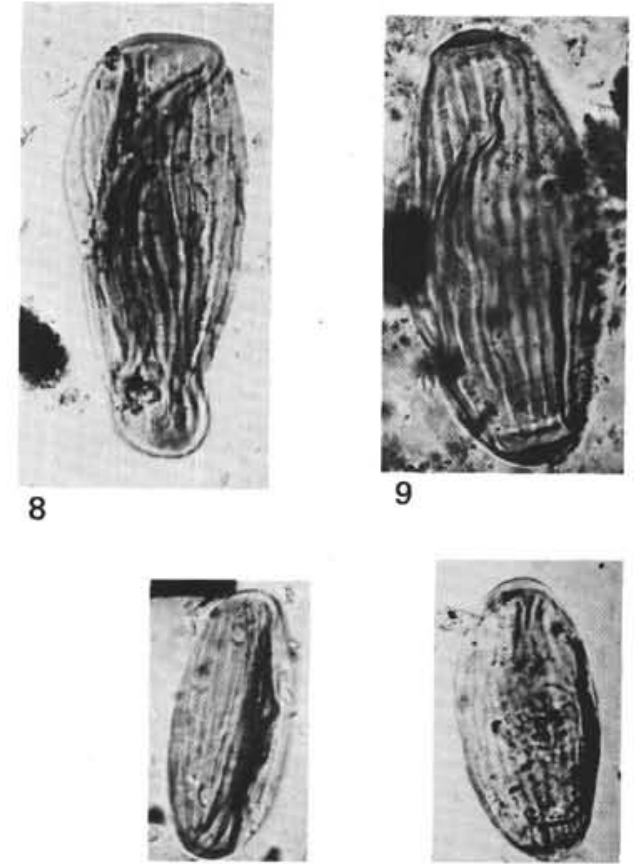

11

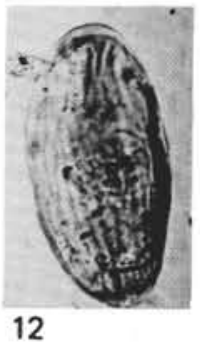

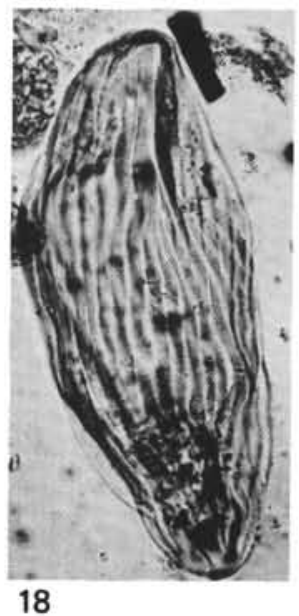




\section{PLATE 9}

Magnification $\times 600$, Figures $13,14, \times 1000$

Figure $1 \quad$ Ephedripites sp. 6.

Morocco Basin, 370-27, CC,

Cenomanian.

Figure 2 Inaperturopollenites $\mathrm{sp}$.

Morocco Basin, 370-27, CC,

Cenomanian.

Figure 3 Araucariacites australis Cookson, 197.

Morocco Basin, 370-41, CC,

Neocomian.

Figures 4-7 Classopollis sp.

13, 14 Morocco Basin, 370-41, CC,

Neocomian.

Figures 8,9 Classopollis sp.

Morocco Basin, 370-32, CC,

Aptian-?lower Albian.

Figures 10-12 Classopollis sp.

Morocco Basin, 370-27, CC,

Cenomanian.

Figures 15, 16 Monosulcites chaloneri Brenner, 1963.

Cape Verde Basin, 367-23, CC,

Cenomanian.

Figures 17-19 Monosulcites sp.

Morocco Basin, 370-41, CC,

Neocomian.

Figure $20 \quad$ Monosulcites sp.

Morocco Basin, 370-27, CC,

Cenomanian.

Figures 21,22 Monosulcites sp.

Cape Verde Basin, 367-23, CC.

Cenomanian.

Figure $23 \quad$ Eucommiidites $\mathrm{sp}$.

Morocco Basin, 370-27, CC,

Cenomanian.

Figures 24-26 Eucommiidites sp.

Morocco Basin, 370-41, CC,

Neocomian.

Figures 27, 28 Vitreisporites pallidus (Reissinger) Nilsson, 1958.

Morocco Basin, 370-41, CC,

Neocomian.

Figures 29, 30 Monocolpopollenites sp.

Cape Verde Basin, 367-23, CC,

Cenomanian. 
PLATE 9
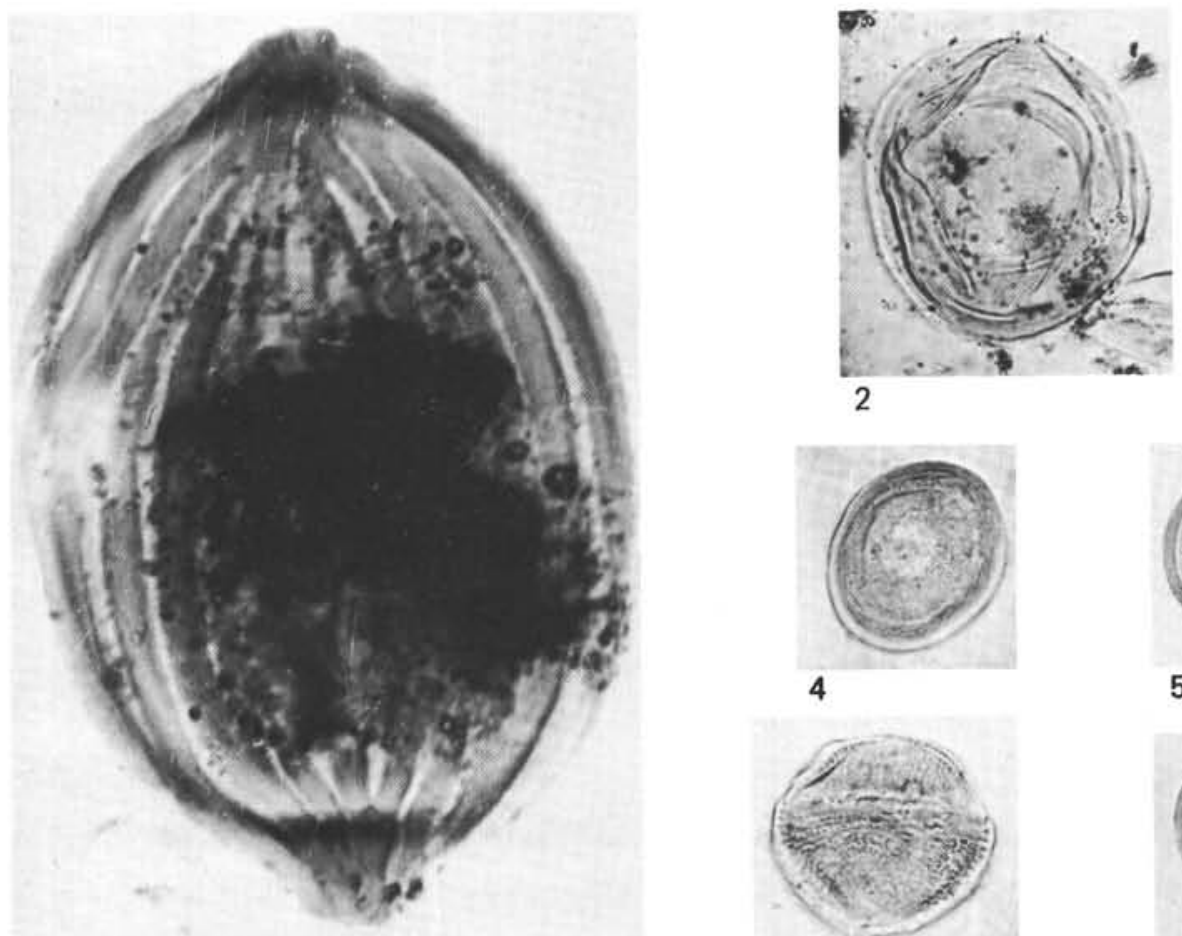

10

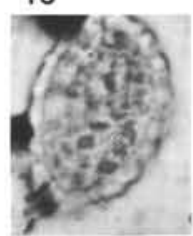

$15 a$

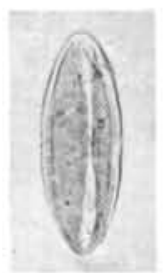

17

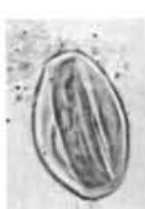

23

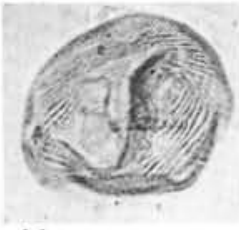

11

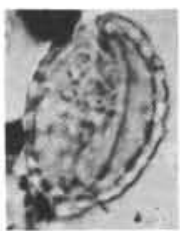

$15 \mathrm{~b}$

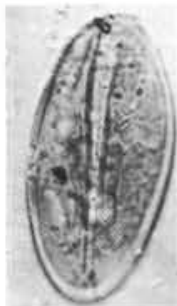

18

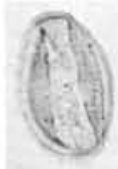

24

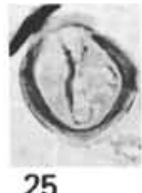

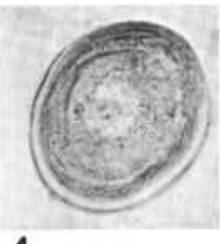

4

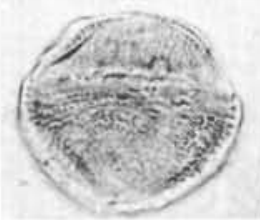

7

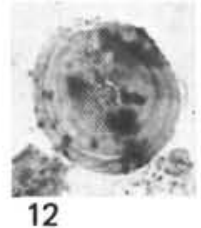

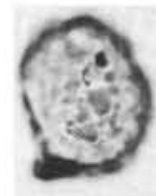

$16 a$

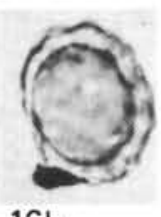

$16 b$

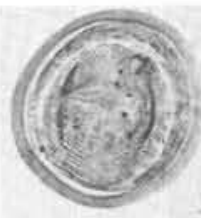

5

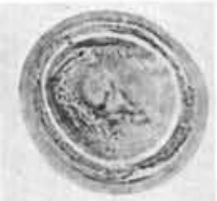

8

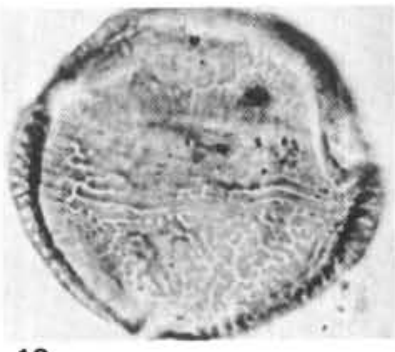

13
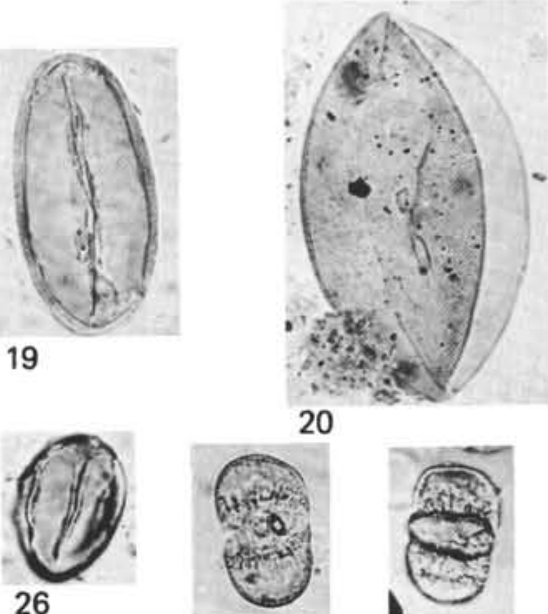

20

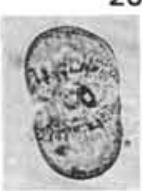

27

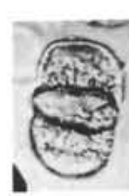

28

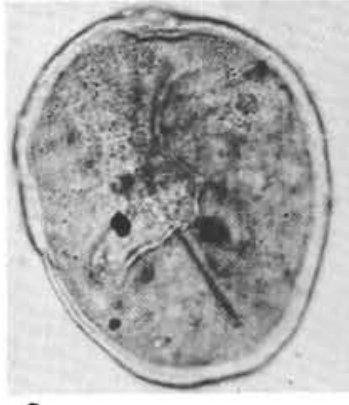

3
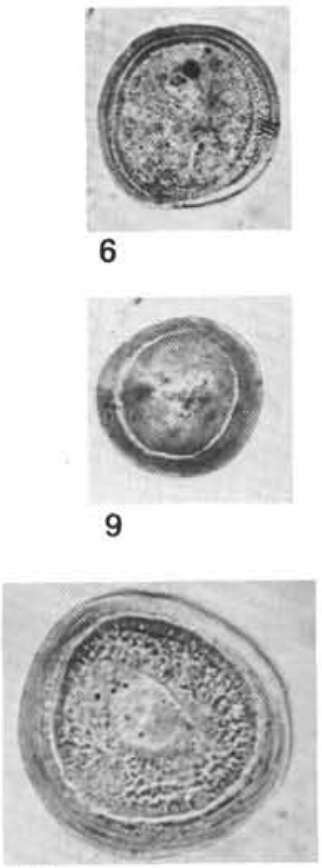

14

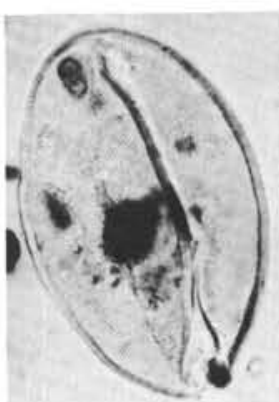

21

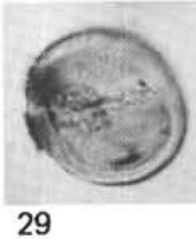

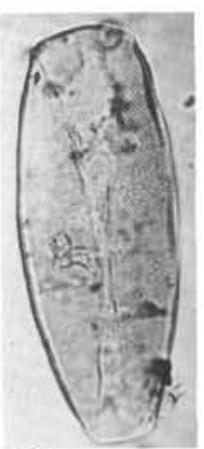

22

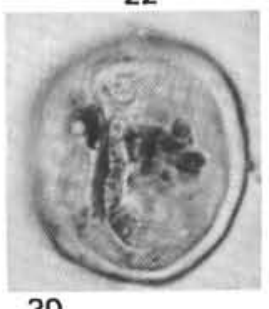




\section{PLATE 10}

Magnification $\times 600$

Figures 1-5 Dicheiropollis etruscus Trevisan, 1971.

Morocco Basin, 370-41, CC,

Neocomian.

Figure $6 \quad$ Pinuspollenites sp.

Morocco Basin, 370-41, CC,

Neocomian.

Figures 7, 8, 11 Podocarpidites sp.

Morocco Basin, 370-41, CC,

Neocomian.

Figure $9 \quad$ Podocarpidites sp.

Morocco Basin, 370-27, CC,

Cenomanian.

Figure $10 \quad$ Podocarpidites sp.

Morocco Basin, 370-32, CC,

Aptian-?lower Albian.

Figures 12, 14 Parvisaccites radiatus Couper, 1958.

Morocco Basin, 370-32, CC,

Aptian-lower Albian.

Figure 13 Parvisaccites radiatus.

Morocco Basin, 370-41, CC, Neocomian.

Figure $15 \quad$ Pinuspollenites $\mathrm{sp}$

Morocco Basin, 370-41, CC, Neocomian.

Figures 16, 17 Tsugaepollenites trilobatus (Balme) Dettmann, 1963.

Morocco Basin, 370-41, CC,

Neocomian.

Figure $18 \quad$ Exesipollenites tumulus Balme, 1957.

Morocco Basin, 370-41, CC.

Cenomanian.

Figure 19 Cerebropollenites mesozoicus (Couper) Nilsson, 1958.

Morocco Basin, 370-41, CC, Neocomian.

Figure 20 Cerebropollenites mesozoicus. Morocco Basin, 370-32, CC, Aptian-?lower Albian 
PLATE 10

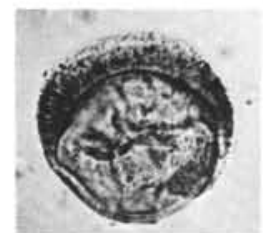

1

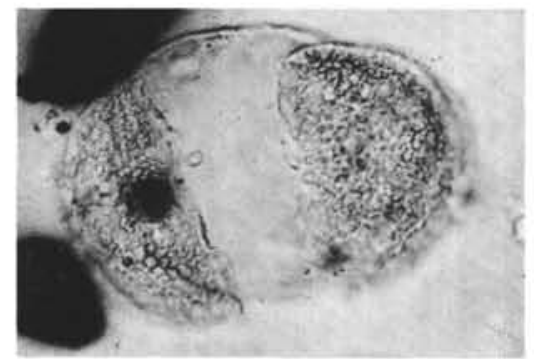

6

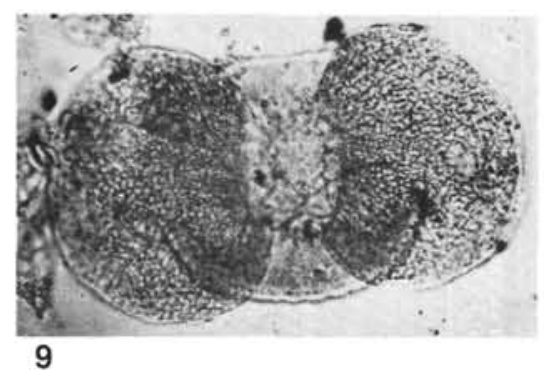

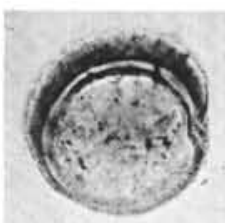

3

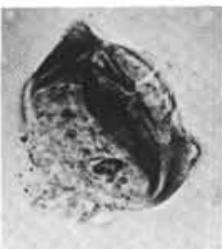

4

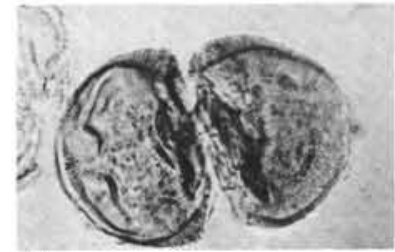

5
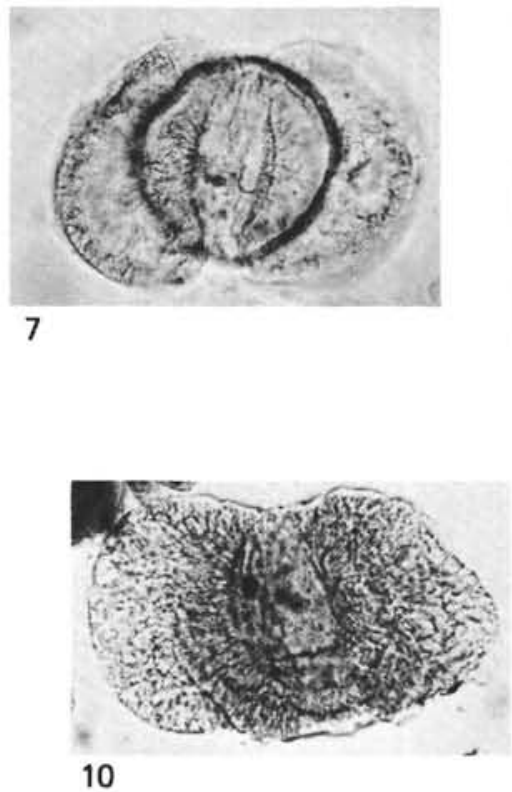
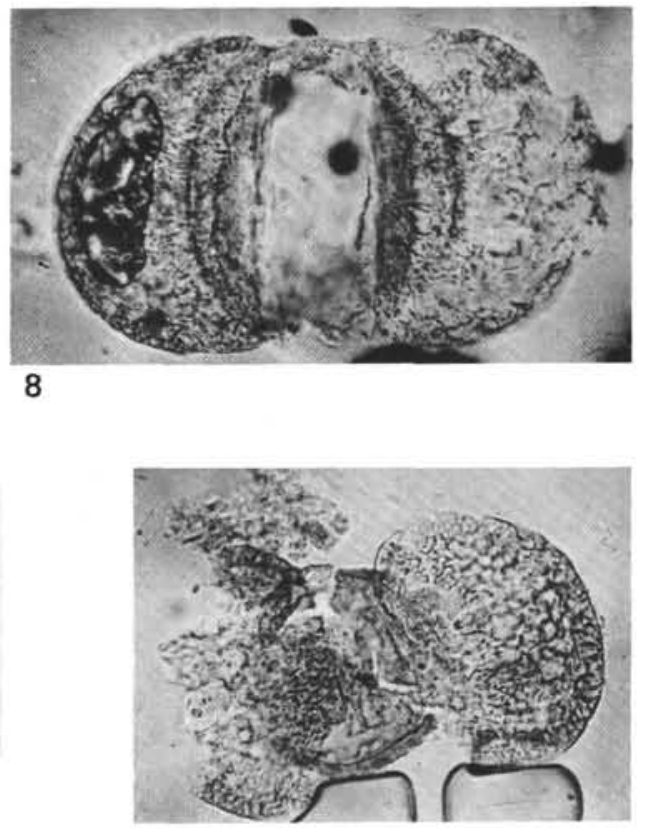

11

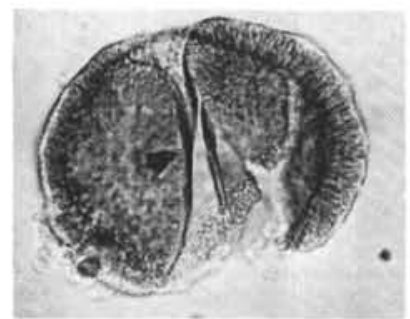

12

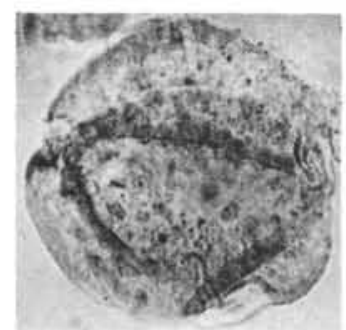

16

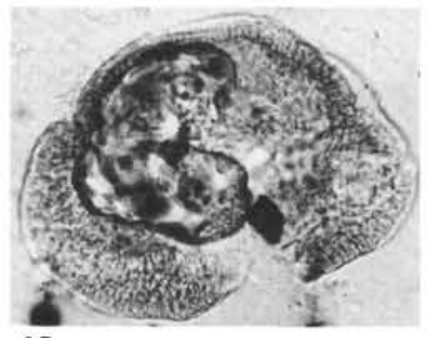

13

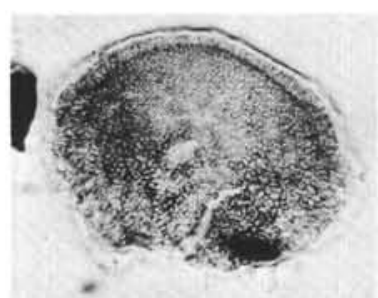

14

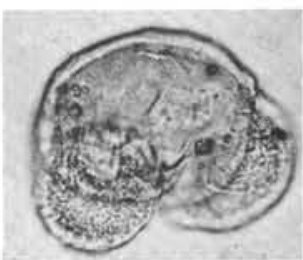

15
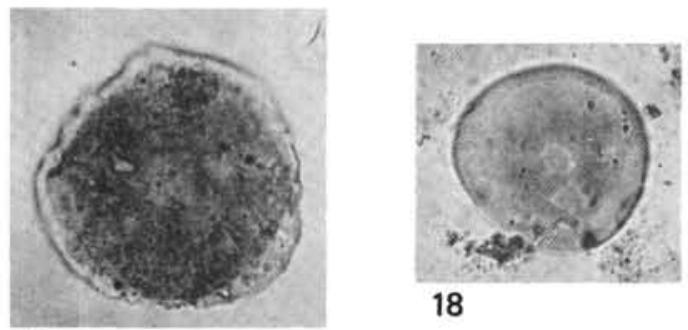

18

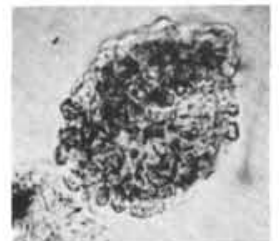

19

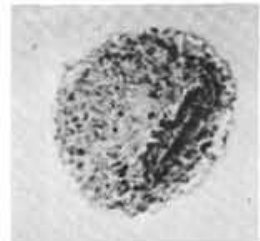

20 
PLATE 11

Magnification $\times 1000$

Figure $1 \quad$ Clavatipollenites hughesi Couper, 1958.

Morocco Basin, 370-32, CC,

Aptian-?lower Albian.

Figure 2 Clavatipollenites rotundus Kemp, 1968.

Morocco Basin, 370-27, CC,

Cenomanian.

Figures 3,4 Asteropollis asteroides Hedlund and Norris, 1968.

Morocco Basin, 370-27, CC,

Cenomanian.

Figures 5-7 Liliacidites peroreticulatus (Brenner) Laing, 1975.

Morocco Basin, 370-32, CC,

Aptian-?lower Albian.

Figure $8 \quad$ Liliacidites peroreticulatus.

Morocco Basin, 370-27, CC,

Cenomanian.

Figures 9, 10 Liliacidites $\mathrm{sp}$.

Cape Verde Basin, 367-23, CC,

Cenomanian.

Figures 11-13 Tricolpites sp. I.

Cape Verde Basin, 367-23, CC,

Cenomanian.

Figure $14 \quad$ Retitricolpites sp. 1.

Cape Verde Basin, 367-23, CC,

Cenomanian.

Figures 15-17 Retitricolpites sp. 2.

Morocco Basin, 370-27, CC,

Cenomanian.

Figure $18 \quad$ Retitricolpites sp. 3.

Morocco Basin, 370-27, CC,

Cenomanian.

Figure $19 \quad$ Retitricolpites sp. 6.

Cape Verde Basin, 367-21, CC,

Cenomanian.

Figure $20 \quad$ Psilatricolpites sp.

Morocco Basin, 370-27, CC,

Cenomanian.

Figure $21 \quad$ Tetradopollenites sp.

Cape Verde Basin, 367-23, CC,

Cenomanian.

Figure 22 Tetradopollenites $\mathrm{sp}$.

Morocco Basin, 370-27, CC,

Cenomanian.

Figures 23, 24 Tricolporopollenites triangulus Groot, Penny and Groot, 1961.

Cape Verde Basin, 367-23, CC,

Cenomanian.

Figures 25,28, Tricolporopollenites sp.

29

Cape Verde Basin, 367-23, CC, Cenomanian.

Figures 26, 27, Tricolporopollenites sp.

32 Morocco Basin, 370-29, CC, lower Albian-lower Cenomanian.

Figures 30, 31 Tricolporopollenites sp.

Morocco Basin, 370-27, CC, Cenomanian. 
PLATE 11

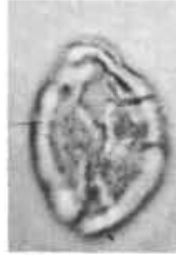

1a

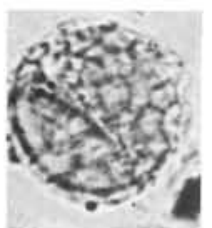

5

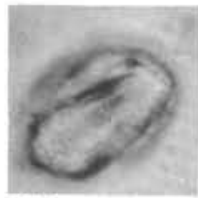

11a

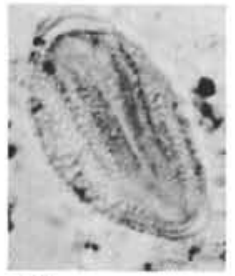

15

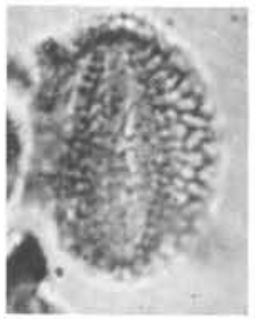

$18 a$

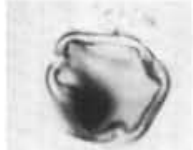

23

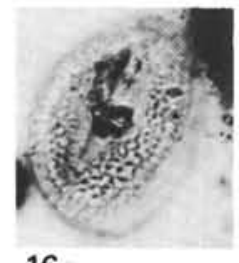

$16 a$

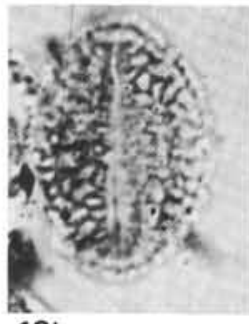

$18 b$

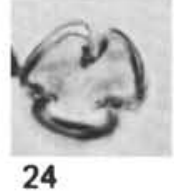

$25 a$

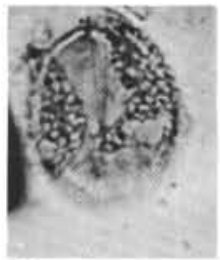

$2 a$

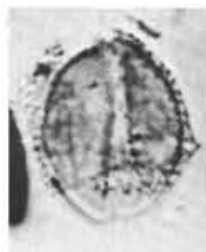

2b
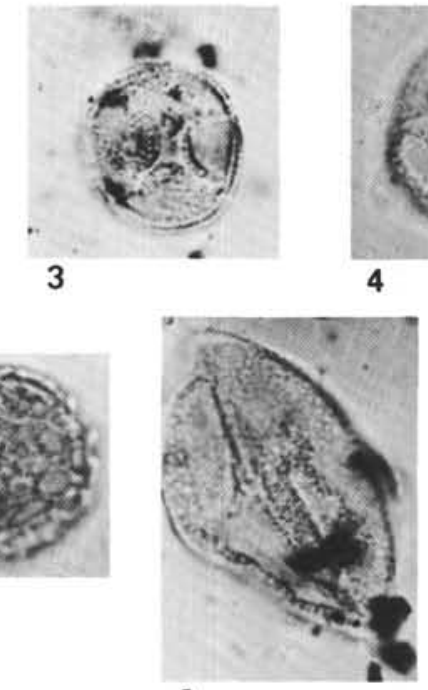

9
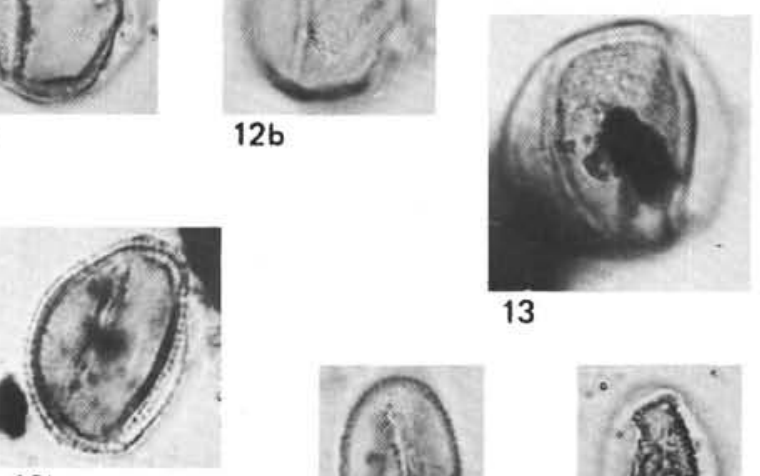

$16 \mathrm{~b}$

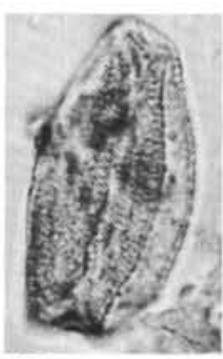

19

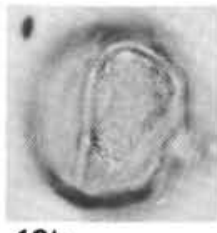

$12 b$
14
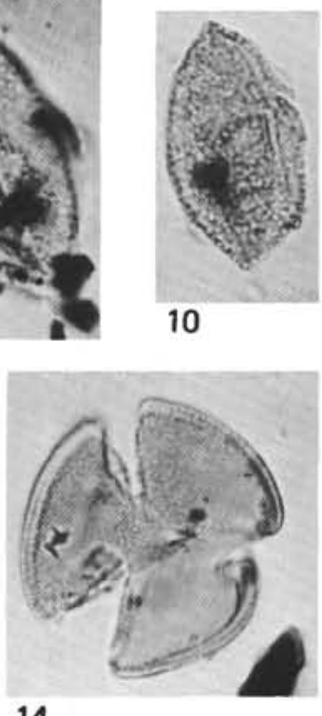

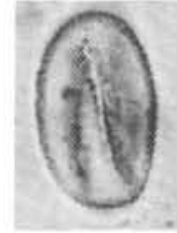

$17 a$
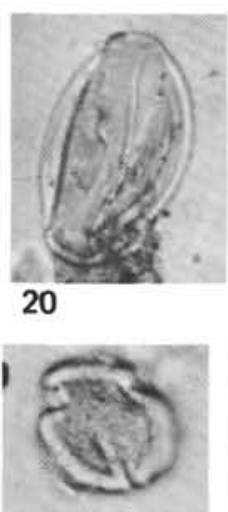

26a

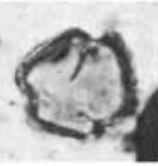

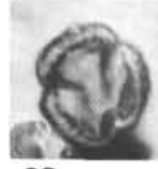

28
$25 b$
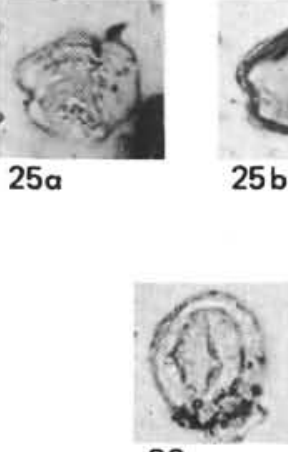

30

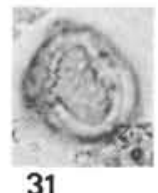

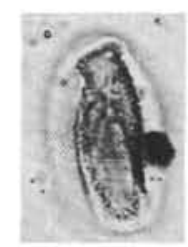

$17 b$
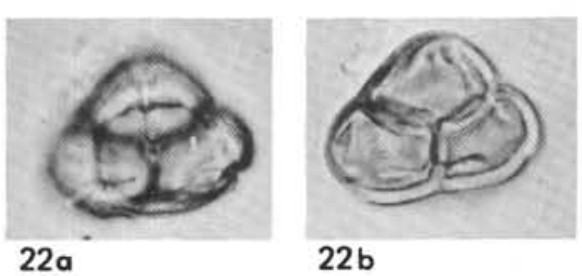

22b

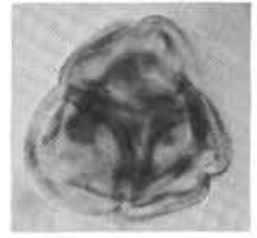

21

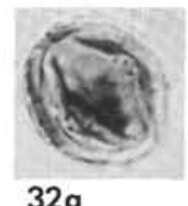

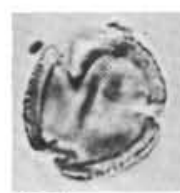

27a

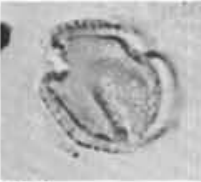

26b

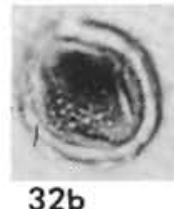


PLATE 12

Magnification $\times 1000$

Figures 1-3 Bacutricolpites $\mathrm{sp}$. 1.

Morocco Basin, 370-27, CC,

Cenomanian.

Figure $4 \quad$ Bacutricolpites sp. 2.

Morocco Basin, 370-29, CC,

upper Albian-lower Cenomanian.

Figures 5,6 Proxapertites $\mathrm{sp}$.

Morocco Basin, 370-29, CC,

upper Albian-lower Cenomanian.

Figure $7 \quad$ ?Tetracolpites sp.

Morocco Basin, 370-29, CC,

upper Albian-lower Cenomanian.

Figure $8 \quad$ Retitricolpites $\mathrm{cf}$. operculatus Herngreen, 1973.

Morocco Basin, 370-27, CC,

Cenomanian.

Figures 9-11 Hexaporotricolpites lamellaferus Jardiné, Doerenkamp and Legoux, 1972.

Morocco Basin, 370-27, CC,

Cenomanian.

Figures 12,13 Striopollenites dubius Jardine and Magloire, 1965.

Morocco Basin, 370-27, CC,

Cenomanian.

Figures 14-17 Tricolpites microstriatus Jardiné and Magloire, 1965.

Morocco Basin, 370-27, CC,

Cenomanian.

Figures 18, 19 Striatopollis sarstedtensis Krutzsch, 1959.

Morocco Basin, 370-27, CC,

Cenomanian.

Figure $20 \quad$ Triporopollenites $\mathrm{sp}$.

Cape Verde Basin, 367-23, CC,

Cenomanian. 
PLATE 12

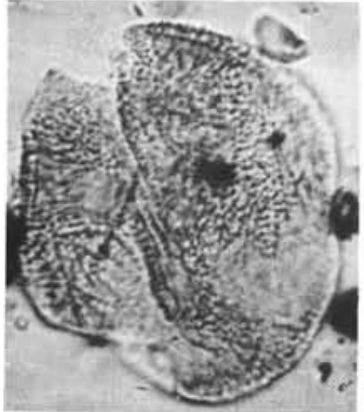

1

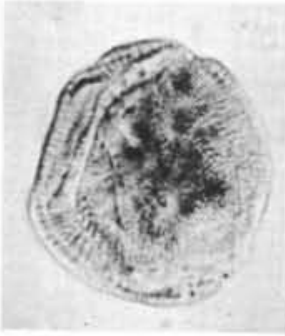

5

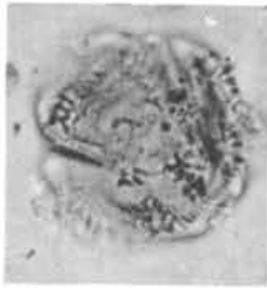

9

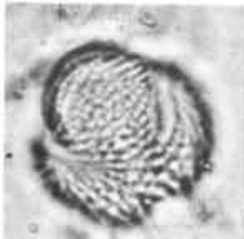

12a

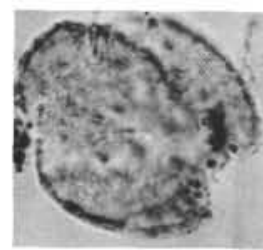

14

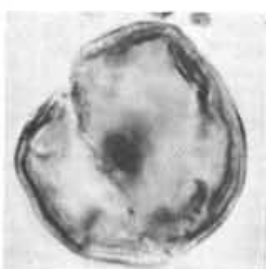

$17 a$

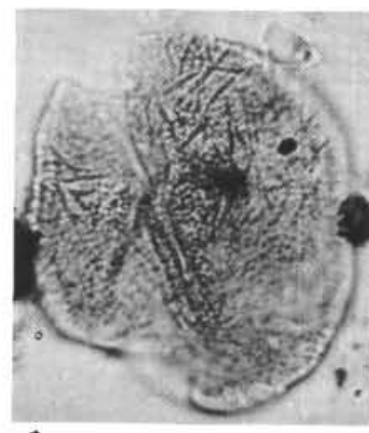

2
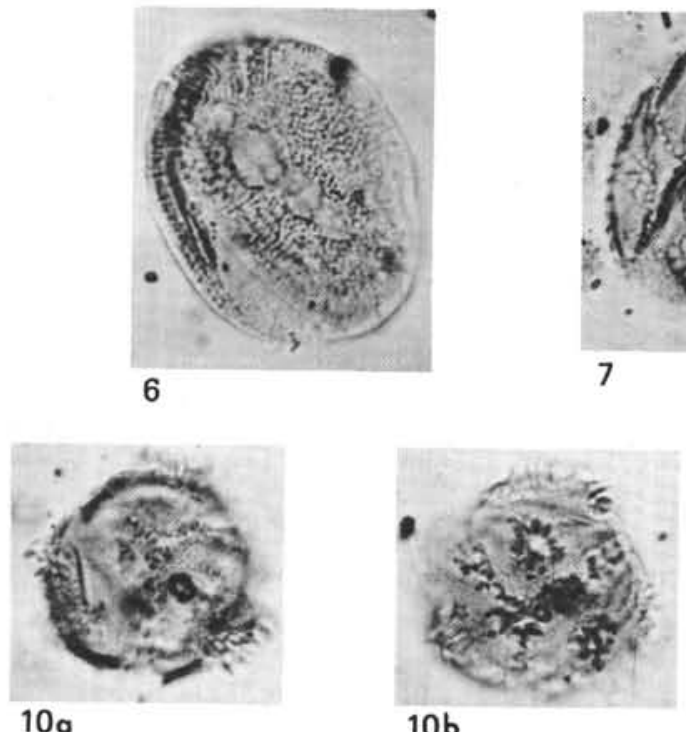

$10 b$
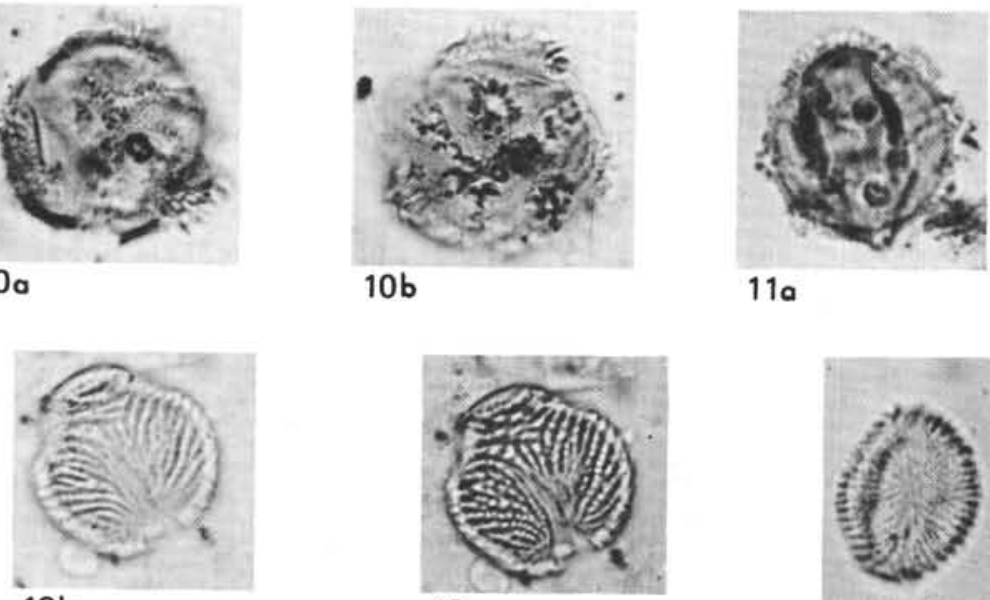

$12 b$

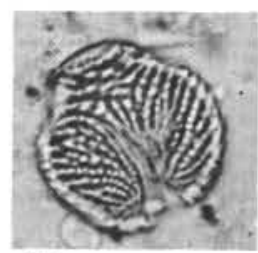

$12 c$

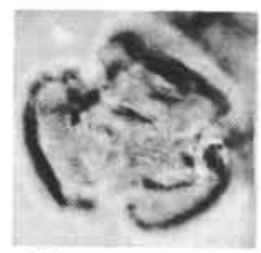

$15 a$

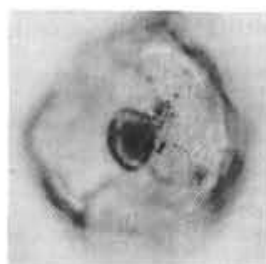

$17 b$

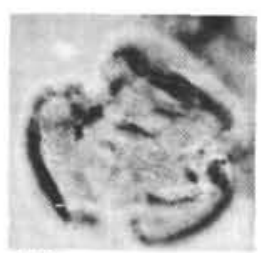

$15 b$

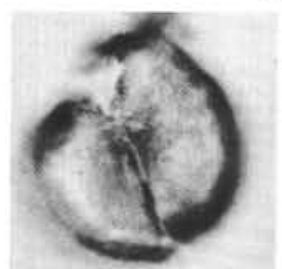

$17 c$

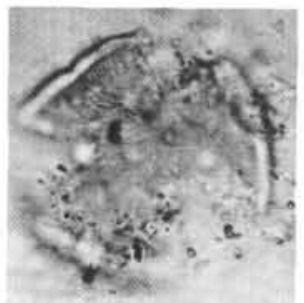

16

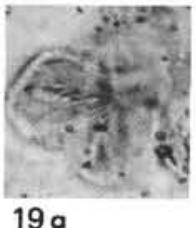

$19 a$

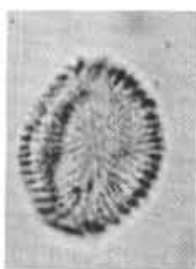

$13 a$

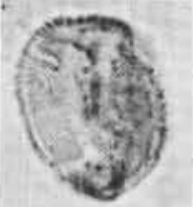

$18 a$

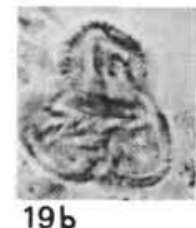

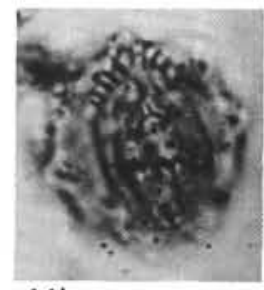

$11 b$

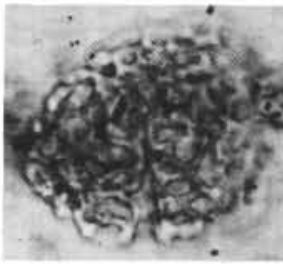

8

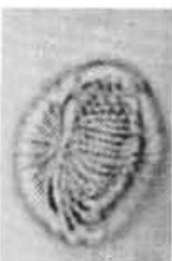

$13 b$

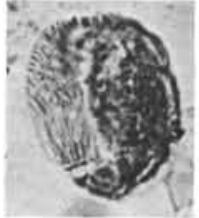

$18 b$

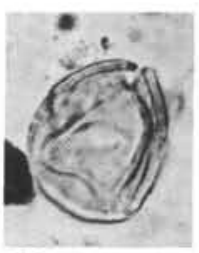

20 
PLATE 13

Magnification $\times 1000$

Figure $1 \quad$ Retitricolpites sp. 4.

Cape Verde Basin, 367-23, CC, Cenomanian.

Figure $2 \quad$ Retitricolpites sp. 5 .

Morocco Basin, 370-27, CC, Cenomanian.

Figure $3 \quad$ Retitricolpites sp. 5.

Cape Verde Basin 367-23, CC, Cenomanian.

Figures 4, $5 \quad$ Tricolpites sp. 2.

Cape Verde Basin, 367-23, CC, Cenomanian.

Figure 6 Tetracolpites sp.

Cape Verde Basin, 367-23, CC, Cenomanian.

Figures 7, $8 \quad$ Tetracolpites sp.

Morocco Basin, 370-23, CC,

Cenomanian.

Figures 9,10 Cretacaeiporites polygonalis (Jardiné and Magloire) Herngreen, 1973.

Cape Verde Basin, 367-23, CC, Cenomanian.

Figures 11, 12 Cretacaeiporites mulleri Herngreen, 1973.

Cape Verde Basin, 367-23, CC,

Cenomanian.

Figures 13,14 Cretacaeiporites scabratus Herngreen, 1973.

Morocco Basin, 370-27, CC,

Cenomanian.

Figures 15-18 Triorites sp.

Morocco Basin, 370-27, CC,

Cenomanian.

Figure 19 Auriculiidites reticulatus Elsik, 1965.

Cape Verde Basin, 367-23, CC,

Cenomanian.

Figures 20,21 Tricolpites cf. giganteus Jardiné and Magloire, 1965.

Cape Verde Basin, 367-23, CC,

Cenomanian. 

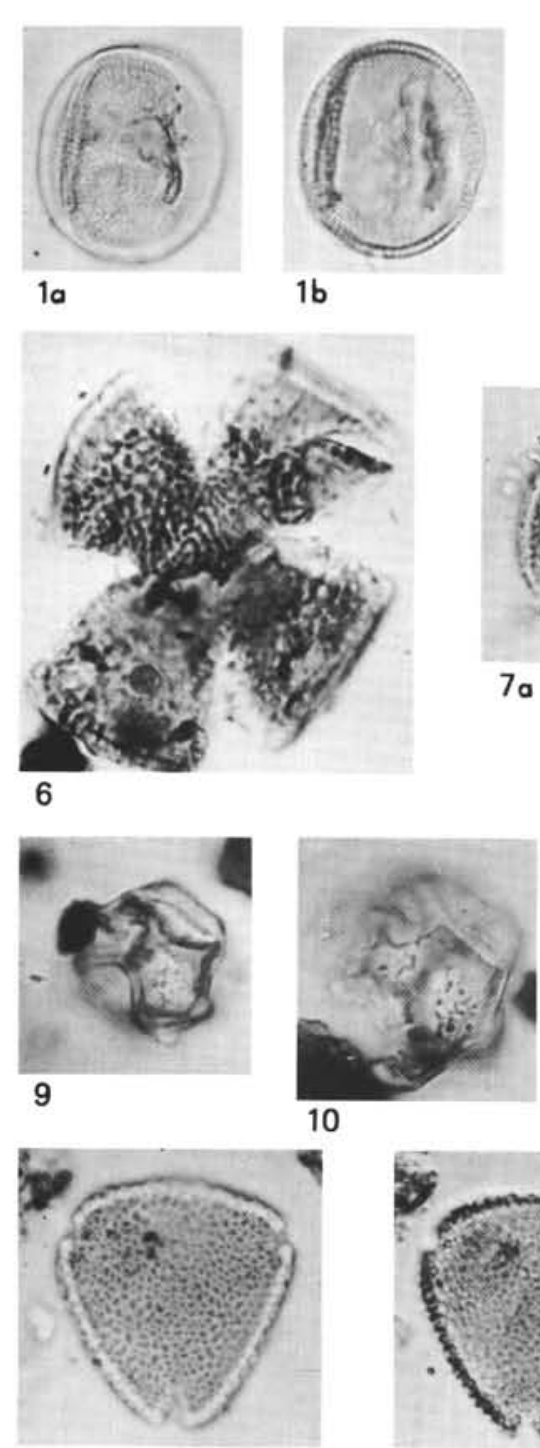

$15 a$

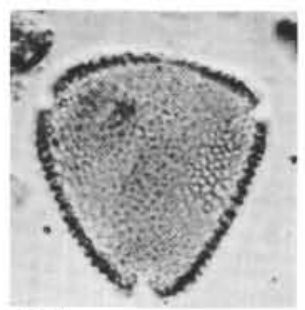

$15 b$

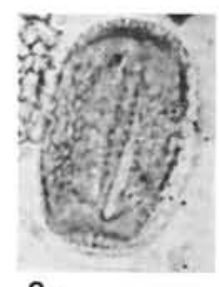

20

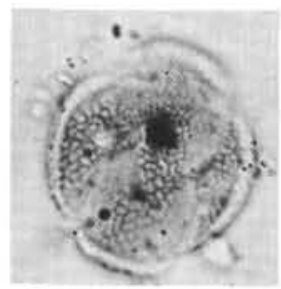

$7 a$

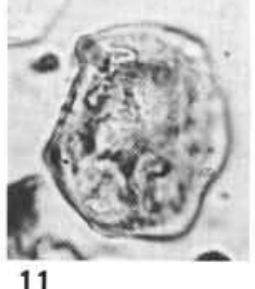

11

\section{PLATE 13}

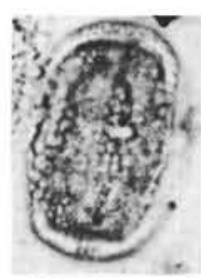

$2 b$

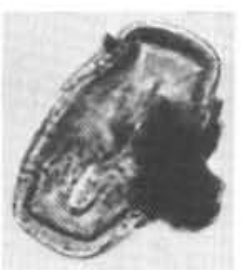

$3 a$

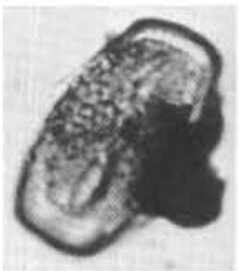

$3 b$

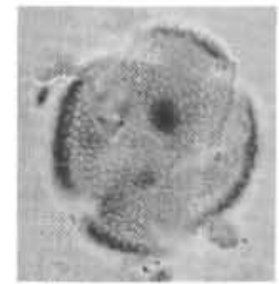

$7 b$

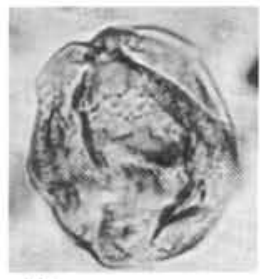

12

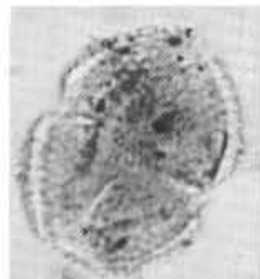

8

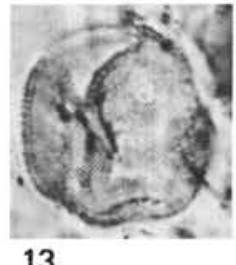

13

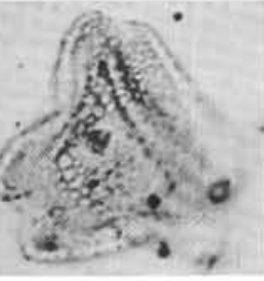

17

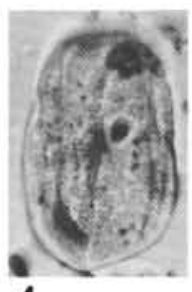

4
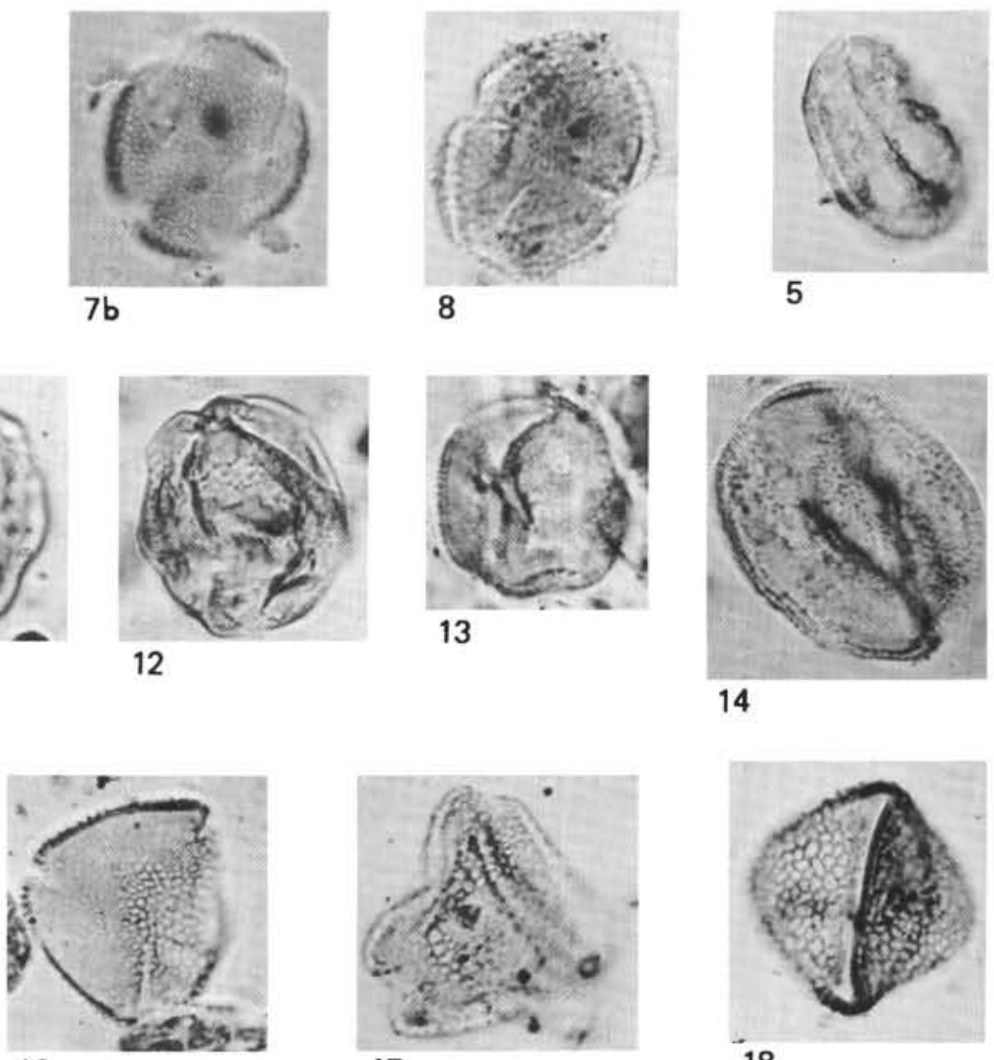

16

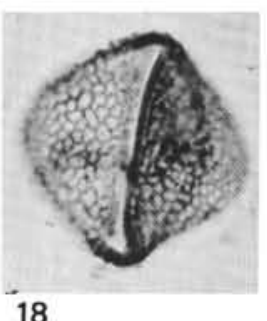

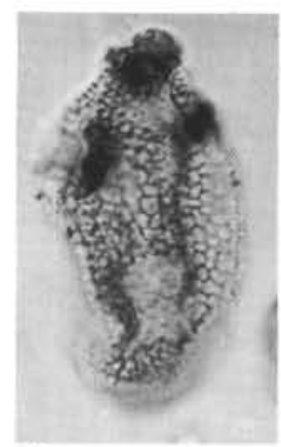

19
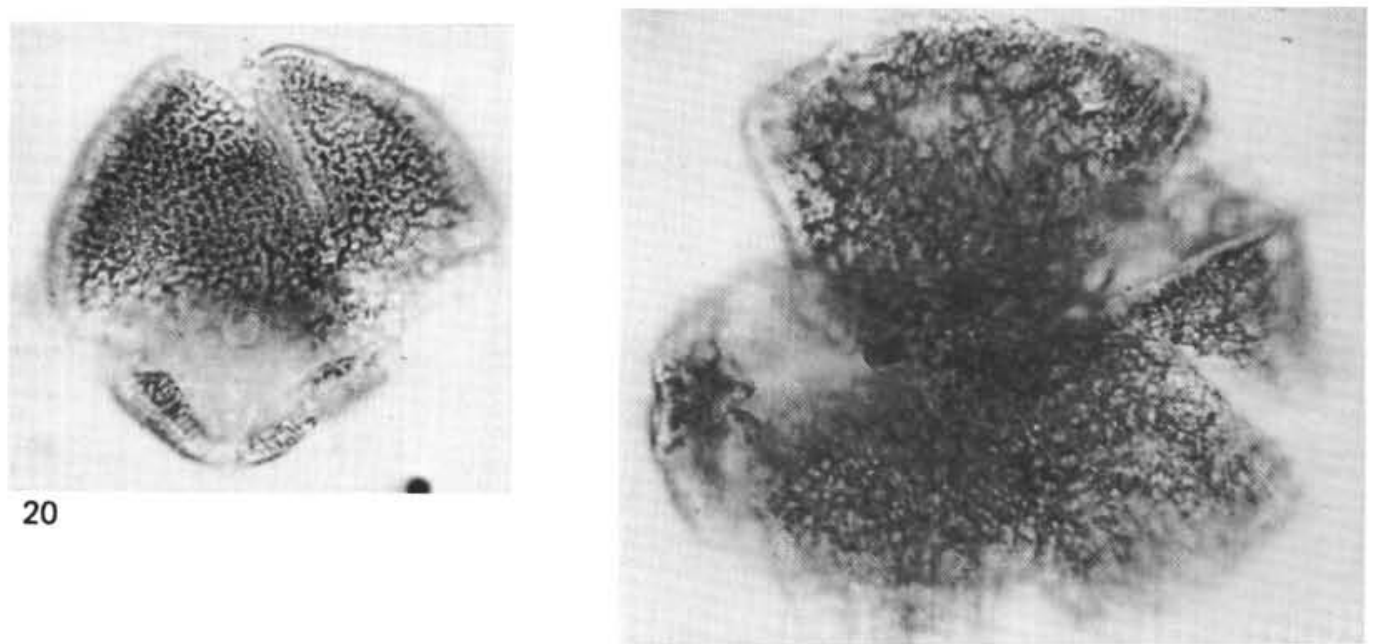
PLATE 14

Magnification $\times 1000$

Figure $1 \quad$ Forma sp. 1.

Cape Verde Basin, 367-23, CC, Cenomanian.

Figure $2 \quad$ Forma sp. 3.

Cape Verde Basin, 367-23, CC, Cenomanian.

Figures 3, 4 Forma sp. 3 .

Cape Verde Basin, 367-23, CC, Cenomanian.

Figure $5 \quad$ Forma sp. 4.

Cape Verde Basin, 367-23, CC, Cenomanian.

Figure $6 \quad$ Forma sp. 5.

Morocco Basin, 370-27, CC,

Cenomanian.

Figure $7 \quad$ Forma sp. 6 .

Cape Verde Basin, 367-23, CC, Cenomanian.

Figure 8

Forma sp. 7.

Cape Verde Basin, 367-23, CC, Cenomanian.

Figure 9

Forma sp. 8.

Cape Verde Basin, 367-23, CC, Cenomanian. 
PLATE 14

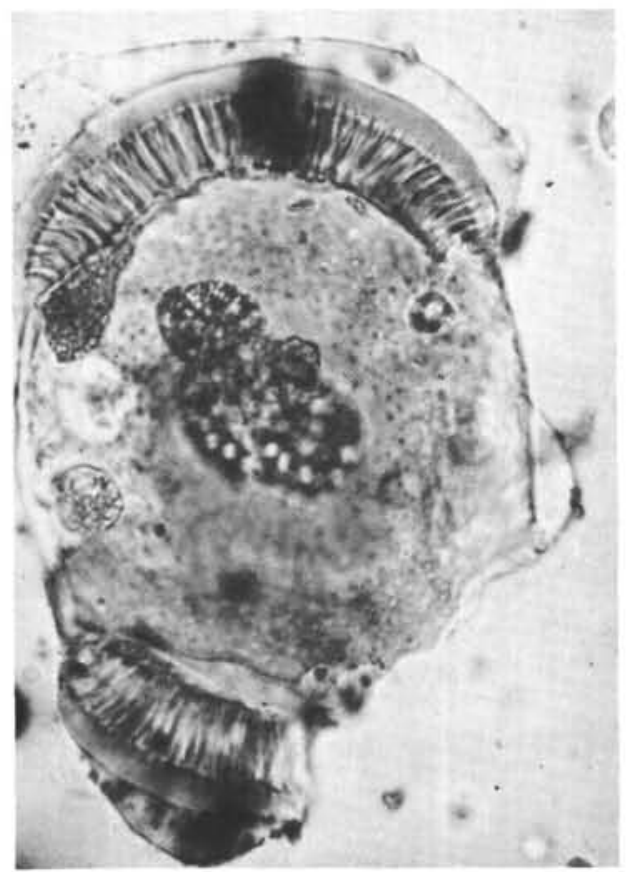

$1 a$
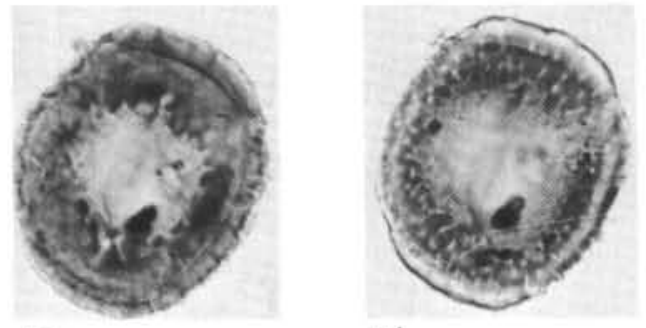

$5 b$

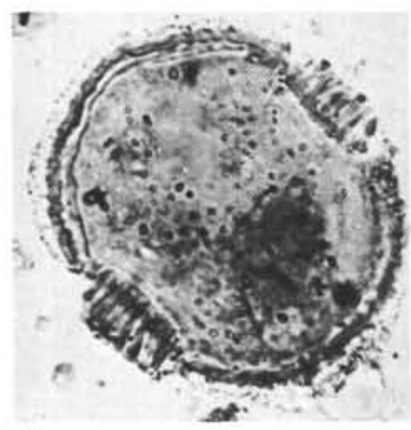

6
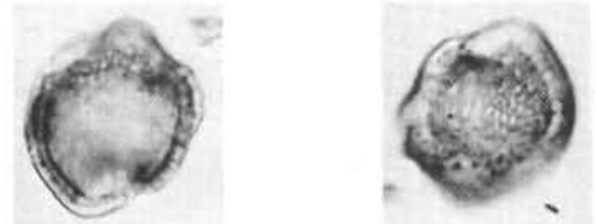

$8 b$

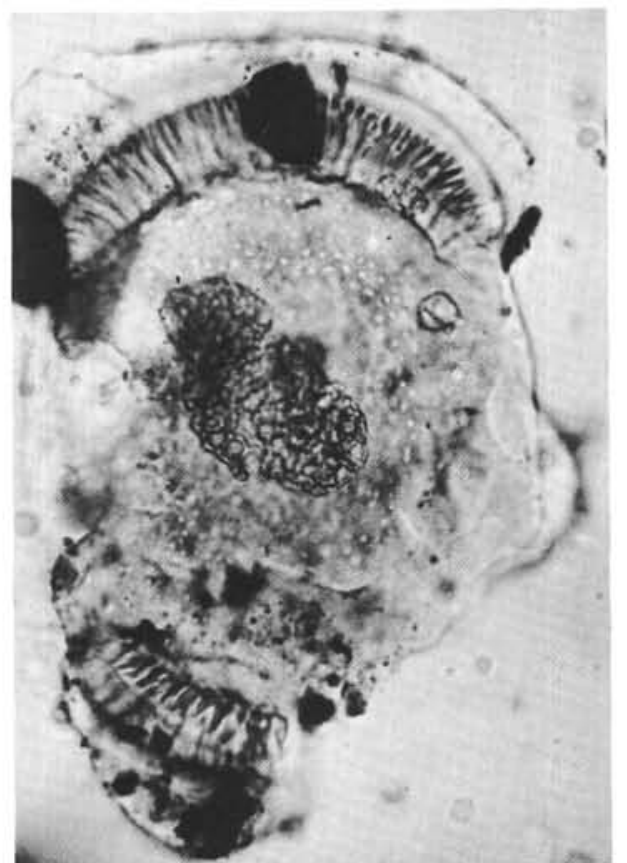

$1 b$

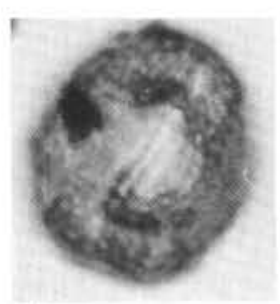

$5 c$

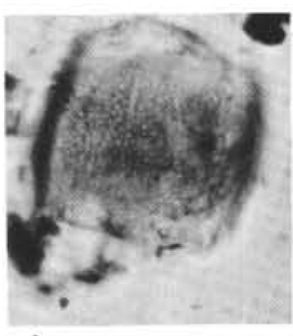

4a

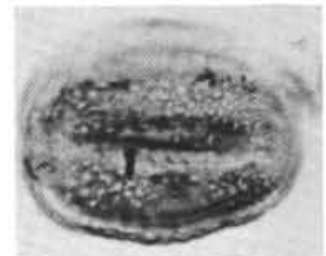

$2 a$

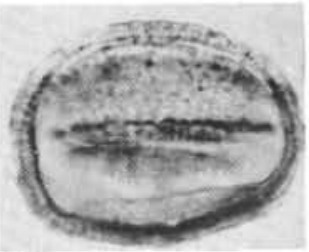

$2 b$

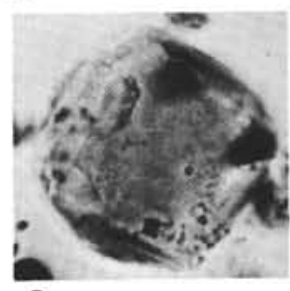

3

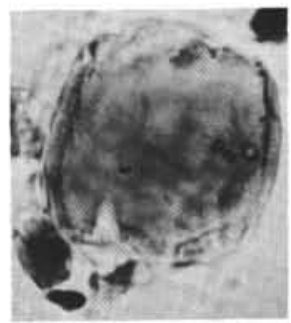

4b

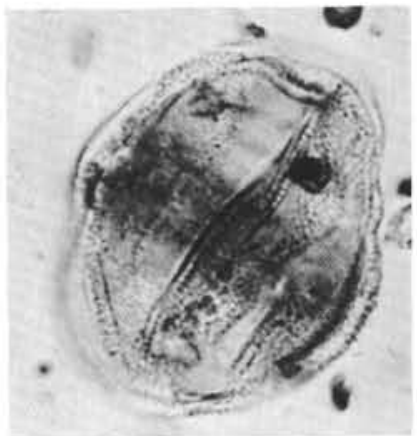

$7 b$

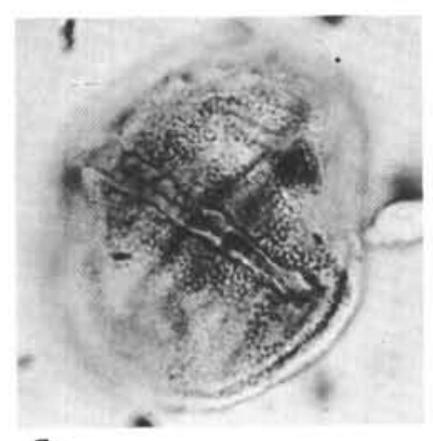

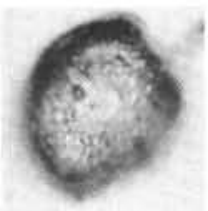

$8 c$

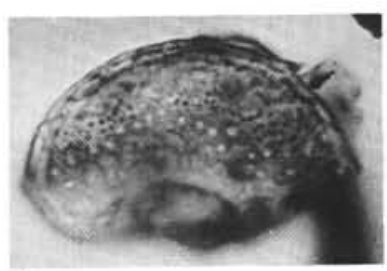

9 